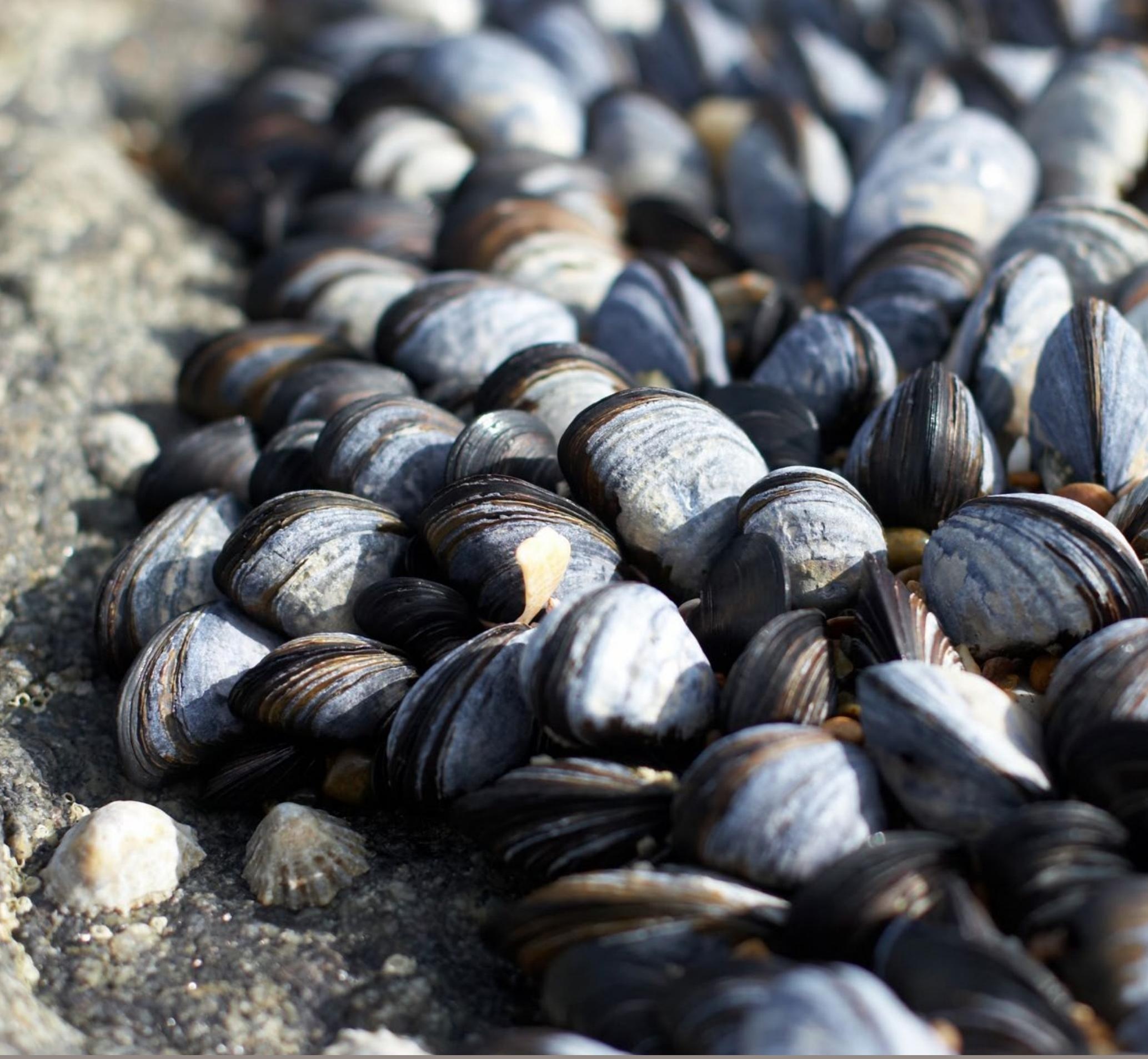

Ontwikkeling van enkele droogvallende mosselbanken in de Nederlandse Waddenzee

Situatie 2019

S.T. Glorius \& A. Meijboom

WOt-technical report 192

WMR-Rapport C108/20

WAGENINGEN

UNIVERSITY \& RESEARCH 

Ontwikkeling van enkele droogvallende mosselbanken in de Nederlandse Waddenzee 
Dit Technical report is gemaakt conform het Kwaliteitsmanagementsysteem (KMS) van de unit Wettelijke Onderzoekstaken Natuur \& Milieu, onderdeel van Wageningen University \& Research.

De WOT Natuur \& Milieu voert wettelijke onderzoekstaken uit op het beleidsterrein natuur en milieu. Deze taken worden uitgevoerd om een wettelijke verantwoordelijkheid van de Minister van Landbouw, Natuur en Voedselkwaliteit (LNV) te ondersteunen. We zorgen voor rapportages en data voor (inter)nationale verplichtingen op het gebied van agromilieu, biodiversiteit en bodeminformatie, en werken mee aan producten van het Planbureau voor de Leefomgeving zoals de Balans van de Leefomgeving.

\section{Disclaimer WOt-publicaties}

De reeks 'WOt-technical reports' bevat onderzoeksresultaten van projecten die kennisorganisaties voor de unit Wettelijke Onderzoekstaken Natuur \& Milieu hebben uitgevoerd.

WOt-technical report 192 is het resultaat van onderzoek gefinancierd door het ministerie van Landbouw, Natuur en Voedselkwaliteit (LNV). 


\title{
Ontwikkeling van enkele droogvallende mosselbanken in de Nederlandse Waddenzee
}

\author{
Situatie 2019
}

S.T. Glorius ${ }^{1} \&$ A. Meijboom ${ }^{1}$

1 Wageningen Marine Research

BAPS-projectnummer WOT-04-009-035.01

Wettelijke Onderzoekstaken Natuur \& Milieu

Wageningen, december 2020

wot-technical report 192

ISSN 2352-2739

DOI $10.18174 / 536455$ 


\section{Referaat}

Glorius, S.T. \& A. Meijboom (2020). Ontwikkeling van enkele droogvallende mosselbanken in de Nederlandse Waddenzee; Situatie 2019. Wettelijke Onderzoekstaken Natuur \& Milieu, WOt-technical report 192. 64 blz.; 19 fig.; 2 tab.; 41 ref; 5 Bijlagen.

Wageningen Marine Research bestudeert de ontwikkeling op de lange termijn van een aantal individuele droogvallende mosselbanken in de Nederlandse Waddenzee met speciale aandacht voor de eigenschappen die het al dan niet overleven van mosselbanken bepalen. Het onderzoek wordt uitgevoerd binnen het WOTthema Informatievoorziening Natuur. Een groot deel van de hier bestudeerde banken blijkt zich te kunnen handhaven sinds de start van het onderzoek (1995). In zijn algemeenheid blijkt dat de mosselbanken na het jaar van ontstaan langzaam in oppervlakte, bedekkingspercentage en populatiedichtheid achteruitgaan en dat het aandeel lege schelpen, macroalgen en zeepokken toeneemt. De afname in oppervlakte en bedekking wordt af en toe tenietgedaan door een goede mosselbroedval, waarna het proces opnieuw begint. Zo ontstaat er een mosselbank met meerdere jaarklassen. Vestiging van Japanse oesters in bestaande mosselbanken blijkt een algemeen verschijnsel, wat resulteert in een toename van de schelpdierbedekking en een afname in de mosselbiomassa.

Trefwoorden: droogvallende mosselbank, litorale mosselbank, mosselen, Japanse oesters, Waddenzee

\section{Abstract}

Glorius, S.T. \& A. Meijboom (2020). Development of intertidal mussel beds in the Dutch Wadden Sea; Situation in 2019. Wageningen, The Statutory Research Task Unit for Nature and the Environment (WOT Natuur \& Milieu), WOt-technical report 192. 64 p.; 19 Figs; 2 Tabs; 41 Refs; 5 Annexes.

Wageningen Marine Research is studying the long-term development of a number of individual intertidal mussel beds in the Dutch Wadden Sea to identify the characteristics that determine the survival of such beds. The study is being carried out as part of the WOT theme Nature Information Infrastructure. A large proportion of the mussel beds have been able to maintain themselves since the beginning of the study (1995). After formation of a new mussel bed they gradually decline in area, coverage and population density, and the proportion of empty shells, macroalgae and barnacles increases. The decline in size and coverage is occasionally reversed by a good mussel spatfall, after which the process starts again. Japanese oysters have settled in all beds, leading to higher shellfish coverage and a decline in mussel biomass.

Keywords: intertidal mussel bed, littoral mussel bed, mussels, Japanese oysters, Wadden Sea

Foto omslag: Shutterstock

\section{(C) 2020 Wageningen Marine Research}

Postbus 57, 1780 AB Den Helder

Tel: (0317) 4809 00; e-mail: sander.glorius@wur.nl

Wettelijke Onderzoekstaken Natuur \& Milieu (unit binnen de rechtspersoon Stichting Wageningen Research), Postbus 47, 6700 AA Wageningen, T 03174854 71, info.wnm@wur.nl, www.wur.nl/wotnatuurenmilieu.

WOT Natuur \& Milieu is onderdeel van Wageningen University \& Research.

Dit rapport is gratis te downloaden van https://doi.org/10.18174/536455 of op www.wur.nl/wotnatuurenmilieu. De WOT Natuur \& Milieu verstrekt geen gedrukte exemplaren van rapporten.

- Overname, verveelvoudiging of openbaarmaking van deze uitgave is toegestaan mits met duidelijke bronvermelding.

- Overname, verveelvoudiging of openbaarmaking is niet toegestaan voor commerciële doeleinden en/of geldelijk gewin.

- Overname, verveelvoudiging of openbaarmaking is niet toegestaan voor die gedeelten van deze uitgave waarvan duidelijk is dat de auteursrechten liggen bij derden en/of zijn voorbehouden.

Wettelijke Onderzoekstaken Natuur \& Milieu aanvaardt geen aansprakelijkheid voor eventuele schade voortvloeiend uit het gebruik van de resultaten van dit onderzoek of de toepassing van de adviezen. 


\section{Woord vooraf}

In deze jaarlijkse werkrapportage wordt de ontwikkeling van enkele individuele mosselbanken beschreven. Dit rapport beschrijft de situatie tot en met 2019. Aan de hand van de ontwikkelingen van de mosselbanken samen wordt een algemeen beeld geschetst van de ontwikkeling van mosselbanken over de jaren. Het project 'Ontwikkeling mosselbanken' wordt uitgevoerd in het kader van de wettelijke onderzoekstaken binnen het thema Informatievoorziening Natuur, gecoördineerd door het ministerie van Landbouw, Natuur en Voedselkwaliteit (LNV). De inventarisaties worden ingebracht in het Trilaterale Monitoring Programma, zoals dat internationaal is overeengekomen voor de Waddenzee (TMAP) en onder andere gebruikt in rapportages over de toestand van de natuur in het Natura 2000gebied Waddenzee. Dit onderzoek zou niet mogelijk zijn zonder de hulp en inzet van de bemanning van de schepen van de Waddenunit van het ministerie van LNV.

Sander Glorius 



\section{Inhoud}

Woord vooraf

$\begin{array}{lr}\text { Inhoud } & 7\end{array}$

$\begin{array}{lr}\text { Samenvatting } & 9\end{array}$

$\begin{array}{lr}\text { Summary } & 11\end{array}$

$\begin{array}{llr}1 & \text { Inleiding } & 13\end{array}$

$\begin{array}{lll}1.1 & \text { Mosselbanken } & 13\end{array}$

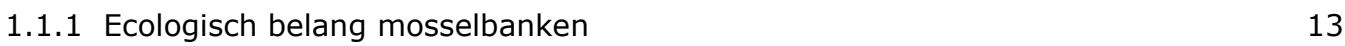

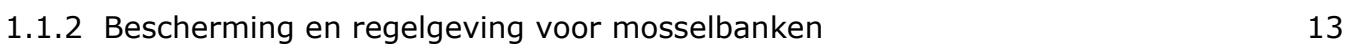

1.1.3 Aanwezigheid en ontwikkeling mosselbanken in het verleden $\quad 14$

$\begin{array}{ll}1.1 .4 \text { Huidige ontwikkeling mosselbanken } & 14\end{array}$

1.2 Doel en aanpak van het onderzoek 14

$\begin{array}{ll}1.2 .1 \text { Doel } & 14\end{array}$

$\begin{array}{ll}1.2 .2 \text { Aanpak } & 15\end{array}$

2 Methode $r$

$\begin{array}{lll}2.1 & \text { Locatie mosselbanken } & 17\end{array}$

\begin{tabular}{ll}
2.2 & Bepalen oppervlakte mosselbank \\
\hline
\end{tabular}

$\begin{array}{llr}2.3 & \text { Bedekkingsmeting } & 18\end{array}$

2.3.1 Raaien en subraaien 18

2.3.2 Verdeling van de raaien $\quad 19$

2.3.3 Score van de mosselbedekking langs de raaien $\quad 20$

$\begin{array}{lll}2.4 & \text { Lengte-frequentieverdeling en samenstelling } & 20\end{array}$

3 Resultaten $\quad 23$

3.1 Ontwikkeling contouren en oppervlakte 23

$\begin{array}{lll}3.2 & \text { Ontwikkeling mosselen en oesters } & 29\end{array}$

$\begin{array}{lll}3.3 & \text { Ontwikkeling dood materiaal en overige fauna } & 34\end{array}$

$4 \quad$ Discussie en conclusie $\quad 39$

$\begin{array}{lr}\text { Literatuur } & 41\end{array}$

$\begin{array}{lr}\text { Verantwoording } & 43\end{array}$

Bijlage 1 Contour per jaar en bank $\quad 45$

Bijlage 2 Kaart - Mosselbedekking $\quad 51$

Bijlage 3 Kaart - Oesterbedekking $\quad 55$

Bijlage 4 Ontwikkeling mosselpopulatie $\quad 59$

$\begin{array}{ll}\text { Bijlage } 5 \text { Ontwikkeling oesterpopulatie } & 61\end{array}$ 



\section{Samenvatting}

Mosselbanken worden algemeen gezien als een belangrijk ecotoop binnen de Waddenzee. In het beheerplan van de Waddenzee voor de periode 2016-2022 (Ministerie van Infrastructuur en Milieu, 2016) is opgenomen dat herstel van droogvallende mosselbanken en zeegrasvelden noodzakelijk is voor verbetering van de kwaliteit van habitattype H1140 'droogvallende zandplaten'. Na het verdwijnen van de droogvallende mosselbanken in de jaren negentig van de vorige eeuw werd betwijfeld of mosselbanken wel meerdere jaren konden blijven bestaan. Daarom wordt binnen dit project sinds 1995 elk jaar een aantal mosselbanken op de droogvallende platen gekarteerd om zodoende de jaarlijkse veranderingen in locatie en bankomvang te kunnen documenteren. Om veranderingen beter te kunnen verklaren, wordt naast het karteren van ieder van de onderzochte mosselbanken ook informatie verzameld over de samenstelling van de bank. Zo worden onder andere bepaald: het met mosselen en oesters bedekte oppervlak, de biomassa- en lengteverdeling van zowel mosselen als oesters en de aanwezigheid van andere organismen op de mosselbank. Hierdoor levert het project ook inzicht in de vestiging en verspreiding van de Japanse oester in de Waddenzee sinds 2000 en de consequentie hiervan voor de mosselpopulaties.

In het voorjaar van 2019 werden de mosselbanken 502 (Ameland Molengatplaat), 503 (Ameland Ballumerbocht), 603 (Schiermonnikoog - Brakzand), 607 (Zuid Oost Lauwers - Zuid) en 640 (Schiermonnikoog - ZOL) bemonsterd. In het najaar werden de mosselbanken 710 (Rottumerplaat) en 736 (Rottumeroog-Oost) en 727 (Rottumeroog - Horsbornzand) bezocht. Mosselbank 727 werd in 2018 voor het eerst waargenomen en in 2019 voor het eerst bemonsterd. Mosselbanken 727 en 736 zijn in 2019 in een laagtij bemonsterd. Voor mosselbank 736 was het alleen mogelijk de buitenste omtrek (contour) op te meten en was er onvoldoende tijd om monsters te nemen. Aan de hand van de veranderingen van de individuele mosselbanken wordt een algemeen beeld geschetst van de ontwikkeling van mosselbanken over de jaren tot en met 2019.

Dit onderzoek wordt uitgevoerd in het kader van wettelijke onderzoekstaken thema Informatievoorziening Natuur, gecoördineerd door het Ministerie van Landbouw Natuur en Voedselkwaliteit (LNV).

Een groot deel van de hier onderzochte banken (502, 503, 603, 710 en 736) blijkt erg stabiel te zijn. Ze hebben zich, door o.a. periodiek terugkomende mosselbroedvallen, sinds de start van het onderzoek in 1995 kunnen handhaven en zijn reeds tussen de 14 en 25 jaar aanwezig op min of meer dezelfde plek. Ook de randen van de mosselbanken blijken, voor een groot deel, opvallend stabiel te zijn. Er blijken echter ook meer dynamische bankdelen te zijn die zich uitbreiden door verschuivingen van bankdelen na storm(en) en/of na een goede zaadval, en weer uiteenvallen na sterfte of wegspoeling. Langjarige bankoverleving is niet vanzelfsprekend. Zo is de afgelopen periode een aantal banken opgenomen in dit onderzoek (101, 606, 703, 726, 734 en 735) geheel of nagenoeg verdwenen nadat deze ongeveer 5 tot 10 jaar aanwezig zijn geweest. De in 2018 nieuwgevormde en bemonsterde bank 640 en de in 2018 nieuwgevormde en in 2019 voor het eerst bemonsterde mosselbank 727 zijn het eerste jaar goed doorgekomen en in 2019 teruggevonden. Enkele mosselpatches van bank 607 zijn in 2019 ook teruggevonden. Omdat vooral de overleving in de eerste vijf jaar onzeker is, is het van belang voor de onderzoeksvraag deze recentelijk gevormde banken de komende jaren te blijven volgen. Japanse oesters worden inmiddels op veel van de hier onderzochte mosselbanken aangetroffen. De vestiging van de Japanse oester heeft grote invloed gehad op de mosselpopulatie. Qua aantallen zijn mosselen nog altijd in de meerderheid, maar qua biomassa is dit voor bijvoorbeeld 502 en 503 al jaren niet meer zo. Het is momenteel niet duidelijk of het effect van oesters op de mosselpopulatie in termen van biomassa uitgewerkt is.

Zoals ook in de eerdere tussenrapportages (in o.a. Glorius et al., 2019) is geconcludeerd, gaan de mosselbanken in het algemeen na het jaar van ontstaan langzaam in oppervlak, bedekkingspercentage, mosseldichtheid en -biomassa achteruit. Op de mosselbanken neemt dan het 
percentage lege schelpen, macroalgen, zeepokken en restgewicht toe in verhouding tot de levende mosselen. De afname in oppervlakte en bedekking wordt af en toe onderbroken door een goede broedval, waarna het proces opnieuw begint. Over de jaren ontstaat dus geleidelijk een mosselbank met meerdere jaarklassen en met een gevarieerde levensgemeenschap. Ondanks de overeenkomsten in algemene ontwikkeling, zijn er grote verschillen te zien in de ontwikkeling tussen individuele mosselbanken binnen een jaar. Deze verschillen kunnen ontstaan door locatie (en dus blootstellingen aan storm en predatie) of door karakteristieken van de mosselbank (de mate waarin deze bestand is tegen stormen en predatie). 


\section{Summary}

Mussel beds are generally regarded as an important ecotope in the Wadden Sea. In the management plan for the Wadden Sea for the period 2016 - 2022, the Ministry of Infrastructure and Environment (2016) stresses the need for a recovery in the areal coverage of littoral mussel beds in order to improve the quality targets set for habitat type H1140. After the disappearance of the littoral mussel beds in the 1990s, it was doubted by some whether mussel beds can continue to exist for several years. The present project comprises the mapping of a number of individual mussel beds to document their current location and size and the changes in these parameters over the years. In addition to these basic assessments, we also have collected data on the characteristics of the mussel beds that were being surveyed, including the coverage of mussels and oysters within the bed, the size and weight of the mussels and oysters, and the presence of other organisms. This research is conducted within the framework of the statutory research tasks theme Nature Information Infrastructure and is coordinated by the Ministry of Agriculture, Nature and Food Quality (LNV).

In the spring of 2019, the following mussel beds were visited and mapped: 502 (Ameland Molengatplaat), 503 (Ameland Ballumerbocht), 603 (Schiermonnikoog), 607 (Zuid Oost Lauwers-Zuid) and 640 (Schiermonnikoog - Zuid Oost Lauwers). The latter was newly formed in 2018. In autumn 2019, mussel beds 710 (Rottumerplaat), 727 (Rottumeroog - Horsbornzand) and 736 (RottumeroogOost) were recorded. Mussel bed 727 was first found in 2018 and consisted of mussel spat. The first measurements on this mussel bed were done in 2019. The mapping of mussel bed 736 in 2019 was limited to recording its boundaries; the coverage and species composition were not recorded.

The results show that most mussel beds included in this project are very stable structures (beds 503, 503, 703, 710 and 736). These beds are periodically replenished by mussel spatfall and have been present for 14 to 25 years without interruption. Large parts of these mussel beds are relative stable and their boundaries do not change much from year to year. Other parts of the beds are more dynamic, expanding as a result of the rearrangement of mussel patches during storm events and/or local spatfall, and subsequently disappearing due to mortality or erosion. Long-term mussel bed survival is far from certain. Several mussel beds $(101,606,726,734$ and 735$)$ have entirely or largely disappeared in recent years after being present for several years $(5-10)$. The mussel beds that were newly formed in 2018 and are being monitored in this project, 640 and 727, have survived the first winter and were discovered and recorded in 2019. Because mussel bed survival is low in the first five years, it is informative for the research question to see how these beds develop in the coming years.

Japanese oysters are now present in most of the investigated beds and have a big influence on the mussel population. Numerically, mussels are still the dominant shellfish species in all beds, but for several years oysters have dominated the shellfish biomass in beds 502, 503, 710 and 736 . It is not clear if the effect of Japanese oyster settlement on the characteristics of the mussel population has reached its full extent.

As described in previous reports (e.g. Glorius et al., 2018), a year after a mussel bed arises, it starts to gradually decrease in size, coverage and mussel density and biomass. This means that the coverage by empty shells, macroalgae, barnacles and other biomass increases relative to that of the living mussels. This decline in size and coverage is occasionally interrupted by new mussel spat deposition, after which the process starts again. Over the years, the mussel bed gradually develops into a diverse community with multiple year classes. Despite the similarities in the general pattern of development, individual mussel beds show major differences in development each year, which may result from the characteristics of the location (e.g. exposure to gales and predators) or of the mussel bed itself (e.g. resistance to gales and predation). 



\section{$1 \quad$ Inleiding}

\subsection{Mosselbanken}

\subsubsection{Ecologisch belang mosselbanken}

Mosselbanken vormen een belangrijk landschappelijk element in de Waddenzee. De mosselbulten van een droogvallende mosselbank kunnen meer dan een meter hoog worden en zijn in het verder vlakke landschap al van verre te zien. Tussen de mosselbulten ontstaan plassen en prieltjes, die soms meer dan 1,5 meter diep kunnen worden. Wanneer bij eb het zeewater zakt, verschijnen de bulten als eerste boven water. Het water stroomt via de prieltjes van de bank, waardoor snelstromende beekjes ontstaan. Zelfs als de mosselen door bijvoorbeeld storm van een mosselbank zijn verdwenen, blijven de ontstane structuren als kleibulten en schelplagen nog jaren zichtbaar en vormen een geschikte vestigingsplaats voor nieuw mosselbroed.

De individuele mosselen in de bank vormen een belangrijke schakel tussen de ecosystemen van het open water en de bodemzone daaronder (Dame, 2011; Prins en Escaravage, 2005). Ze filteren slib en organisch materiaal uit het water en leggen dat vast (Prins et al., 1998). Hiermee verhogen zij de lokale productie (Asmus \& Asmus, 1991; Dame et al., 1991; Petersen et al., 2012). Daarnaast vormen zij door de stabiele structuur een hard substraat in een verder 'zachte' omgeving. Door deze eigenschappen bieden mosselbanken structuur en leefruimte aan andere soorten (Nehls et al., 1997; Gutiérrez et al., 2003; Buschbaum et al., 2009). Op de mosselen zelf groeien zeepokken, macroalgen en andere soorten die graag op hard substraat voorkomen. Tussen de mosselen vinden soorten als de alikruik een geschikte leefomgeving en in de poeltjes tussen de mosselbulten zwemmen vissen als grondels en botten en andere bodemdieren als garnalen.

Mosselbanken vormen 'hotspots' in de omgeving; de biodiversiteit binnen de mosselbank is hoger dan in het aangrenzende zandige wad (Günther, 1996; Markert et al., 2010; Buschbaum et al., 2009; Kochmann et al., 2008). Zowel het aantal soorten als de diversiteit is afhankelijk van de leeftijd en complexiteit van de mosselbank (Tsuchiya \& Nishihira, 1985; Tsuchiya \& Nishihira, 1986). De mosselen op de mosselbank en de aan mosselbanken geassocieerde soorten vormen een voedselbron voor vogels en grote vissen. In de jaren tachtig van de vorige eeuw telde Zwarts (1991) $25 \%$ van alle wadvogels op de mosselbanken, die toen $3 \%$ van het droogvallende wad innamen. Ook Ens \& Alting (1996) vonden een positieve correlatie tussen vogeldichtheden en mosselbanken.

\subsubsection{Bescherming en regelgeving voor mosselbanken}

Mosselbanken vormen een belangrijk onderdeel voor een goede structuur en functie van habitattype H1140 'bij eb droogvallende slikwadden en zandplaten' binnen de Wet natuurbescherming. Daarnaast zijn binnen deze wet instandhoudingsdoelstellingen opgesteld voor verschillende vogelsoorten waarvoor schelpdieren een belangrijke voedselbron vormen, zoals scholeksters. Mosselen en mosselbanken zijn hiermee wettelijk beschermd als belangrijke componenten in het ecosysteem.

In het beheerplan van de Waddenzee voor de periode 2016-2022 (Ministerie van Infrastructuur en Milieu, 2016) is opgenomen dat herstel van droogvallende mosselbanken en zeegrasvelden noodzakelijk is voor verbetering van de kwaliteit van habitattype H1140 'droogvallende zandplaten'. Om dit doel voor mosselbanken te bereiken, zijn gebieden gesloten voor mosselzaadvisserij, zoals het referentiegebied Rottum bijvoorbeeld, en wordt mosselzaadvisserij op de overige wadplaten slechts toegestaan op jonge en instabiele mosselbanken onder zeer strikte voorwaarden, waaronder de aanwezigheid van minimaal 2000 ha meerjarige litorale mosselbanken (LNV, 2004). Na 1994 is er alleen in 2001 nog op enkele mosselbanken op het droogvallende wad gevist en dat betrof onderzoek. 


\subsubsection{Aanwezigheid en ontwikkeling mosselbanken in het verleden}

Droogvallende mosselbanken kwamen in het verleden naar alle waarschijnlijkheid veel in de Waddenzee voor. De banken kenmerken zich door een grote mate van plaatsvastheid, waardoor duidelijke 'mosselgebieden' aan te wijzen zijn (Dankers et al., 2003, 2006; Dankers \& Fey, 2015). De eerste kwantitatieve schatting - gebaseerd op luchtfoto-interpretatie - van de volledige Waddenzee werd gemaakt door Dijkema et al. (1989). Zijn kaart, gebaseerd op de situatie eind jaren zeventig, geeft een areaal van 4152 ha \pm 4200 ha (Dankers en Koelemaij, 1989; Tydeman, 1996).

Retrospectief onderzoek in het kader van EVA II (Evaluatie Schelpdiervisserijbeleid) komt uit op uiterste grenzen tussen 1000 en 6000 hectare (Dankers et al., 2003).

In de jaren tachtig van de vorige eeuw nam het areaal mosselbanken af door intensieve visserij en strenge winters. In het voorjaar van 1987 was er nog slechts 650 ha over, maar op oude banken ontwikkelden zich nieuwe banken die in de jaren 1988-1990 opnieuw werden weggevist. Tussen 1991 en 1994 was er minder dan 200 ha over (Dankers et al., 2003). Veel banken die daarna in de jaren negentig ontstonden, waren niet stabiel genoeg om winterstormen en ijsschade te overleven (Dankers et al., 2004), maar geleidelijk nam het areaal weer toe.

\subsubsection{Huidige ontwikkeling mosselbanken}

Jaarlijks wordt in opdracht van het Ministerie van Landbouw, Natuur en Voedselkwaliteit (LNV), binnen de wettelijke onderzoekstaken op het gebied van visserij, door Wageningen Marine Research het totale areaal aan droogvallende mossel- en oesterbanken geschat, alsmede de totale biomassa in deze banken (Van den Ende et al., 2019). Uit deze inventarisatie is gebleken dat er in het voorjaar van 2019 een areaal van 1647 ha aan mosselbanken, 1104 ha aan gemengde mossel-/oesterbanken en 205 ha aan oesterbanken aanwezig was (Van den Ende et al., 2019; Tabel 3, p.17). Het areaal aan mosselbanken (puur en gemengd met oesters) komt hiermee op 2751 ha, waarmee het areaal met ongeveer $10 \%$ is toegenomen t.o.v. het jaar 2018. Het areaal mosselbanken bestaat voor $24 \%$ uit mosselzaad, wat ruim meer is dan in 2018 toen er nagenoeg geen mosselzaadbanken waren. In 2019 hebben zich dus nieuwe zaadbanken gevormd wat tot een toename geleid heeft van het totale mosselbankareaal in de Waddenzee.

\subsection{Doel en aanpak van het onderzoek}

\subsubsection{Doel}

Het doel van het project is het ter beschikking krijgen van gedetailleerde informatie over de toestand en langjarige ontwikkeling van een aantal mosselbanken in de Waddenzee.

De volgende onderzoeksvraag wordt gesteld:

Hoe ontwikkelen individuele mosselbanken zich met betrekking tot oppervlakte, bedekkingspercentage, lengte-frequentieverdeling en (soorten)samenstelling over de lange termijn?

Het project 'Ontwikkeling mosselbanken' werd de eerste jaren (1995 tot en met 2006) uitgevoerd in opdracht van de LNV Directie Wetenschap en Kennisoverdracht (DWK), maar vanaf 2006 wordt het uitgevoerd in het kader van wettelijke onderzoekstaken thema Informatievoorziening Natuur, gecoördineerd door LNV (voorheen Ministerie van Economische zaken). De inventarisaties worden ingebracht in het Trilaterale Monitoring- en Beoordelingsprogramma (TMAP) en onder andere gebruikt in rapportages over de toestand van de natuur in het Natura 2000-gebied Waddenzee. 


\subsubsection{Aanpak}

Om de langetermijnontwikkeling van mosselbanken te bestuderen, wordt een aantal mosselbanken gekarteerd om de locatie en omvang op dat moment vast te stellen, alsmede jaarlijkse veranderingen hierin te kunnen documenteren. Om geobserveerde veranderingen beter te kunnen verklaren, wordt naast het karteren van ieder van de onderzochte mosselbanken ook informatie verzameld over de samenstelling van de bank. Zo wordt o.a. bepaald:

- het met mosselen en oesters bedekte oppervlak;

- biomassa- en lengteverdeling van mosselen \& oesters;

- de aanwezigheid van overige bodemfauna, zoals wieren, krabben en overige schelpdieren.

Binnen dit project wordt een aantal mosselbanken, gelegen in de oostelijke Waddenzee, gevolgd. In 2019 zijn acht banken bezocht. In het voorjaar zijn zes banken bezocht waarvan er drie sinds de jaren negentig gevolgd worden, twee sinds het jaar 2002 en een die voor het eerst bezocht werd in 2018. Ook is in het voorjaar een locatie bezocht om vast te stellen of er mosselzaad aanwezig was. Op deze locatie bevond zich in de periode 2002 tot en met 2007 een mosselbank. In het najaar werden drie banken bezocht die zich op wadplaten bevinden gelegen onder de 'Rottums' (de eilandengroep Rottumerplaat, Rottumeroog en Zuiderduintjes). Deze banken worden sinds 2006 gevolgd. De monsternamen van deze banken worden gecombineerd met het veldwerk dat uitgevoerd wordt in de geulen van het referentiegebied Rottum. Deze bemonstering vindt in het najaar plaats. Deze banken kunnen daarom al te maken gehad hebben met broedval uit hetzelfde jaar. 



\section{$2 \quad$ Methode}

\section{$2.1 \quad$ Locatie mosselbanken}

In Figuur 2.1 worden de mosselbanken weergegeven die in het kader van dit onderzoek (in het jaar 2019 en daarvoor) onderzocht werden. In april/mei 2019 werden de mosselbanken 502, 503, 603, 607 en 640 (ontstaan in 2018) onderzocht. Ook werd een locatie bezocht waar zich in de periode 2002 tot en met 2007 een mosselbank (606) bevond. In oktober 2019 werden de mosselbanken 710 en 736 onderzocht in het kader van het project TMAP-Rottum. Ook is toen, voor het eerst in het kader van dit onderzoek, een bank onderzocht die in 2018 ontstaan is, nummer 727 in Figuur 2.1. Mosselbanken 101, 703, 726, 734 en 735 werden niet meer bezocht; mosselbank 101 in verband met het gekrompen budget en 703, 726, 734 en 735 omdat ze in de voorgaande jaren zijn verdwenen.

Voor het meten van mosselbank 727 en 736 was een laagwater getij beschikbaar. Vanwege de relatief kort beschikbare tijd was het niet mogelijk alle metingen (omtrek, bedekking en monsters, zie onder), op zowel mosselbank 727 als 736 te doen. Mosselbank 727 is recentelijk (in 2018) ontstaan en daarom is het de verwachting dat deze bank minder stabiel en meer veranderlijk is dan bank 736 . Daarom is ervoor gekozen om voor bank 727 alle metingen te verrichten en de metingen voor mosselbank 736 te beperken tot het inmeten van de bankcontour.

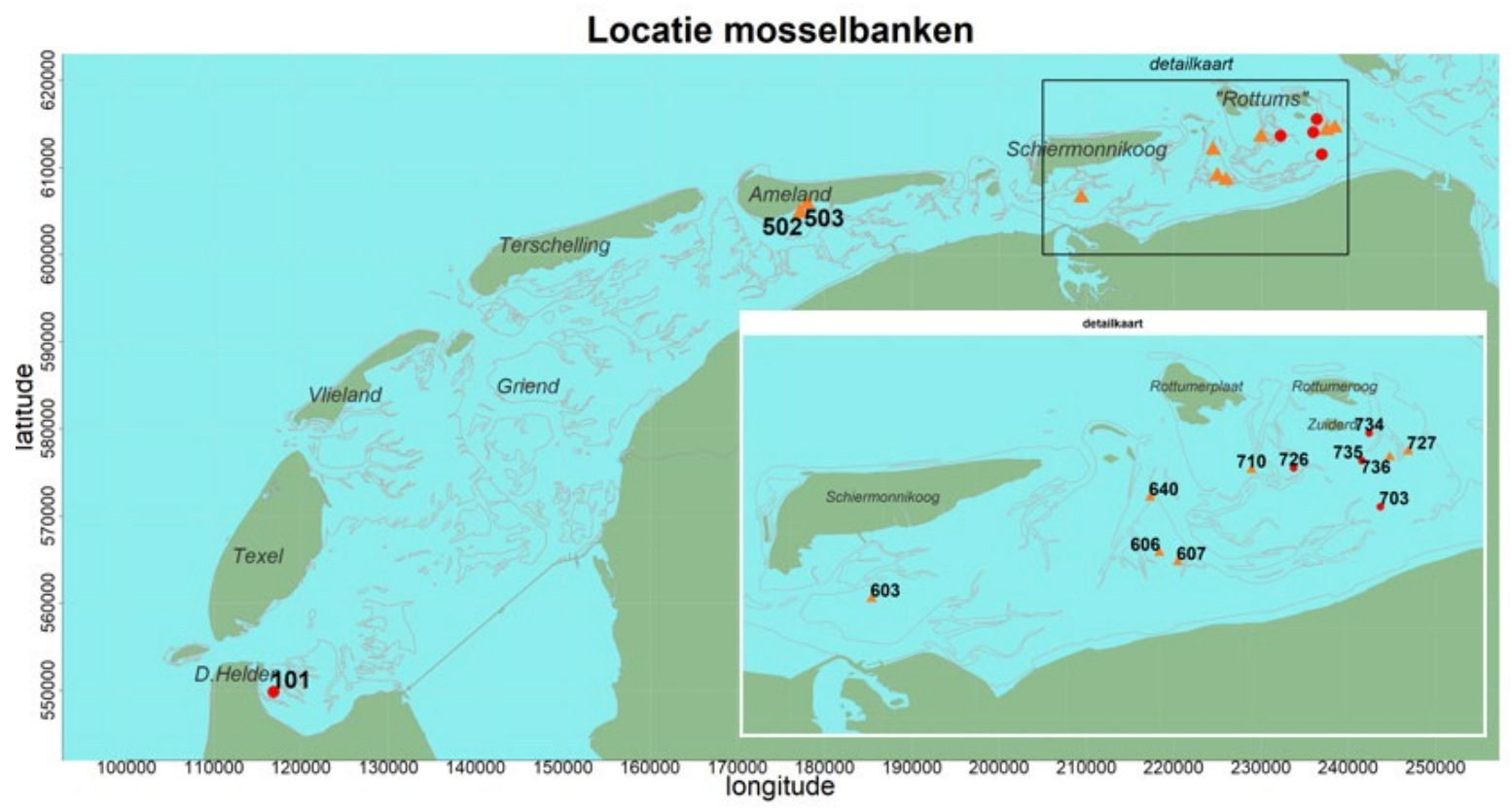

Figuur 2.1 Locatie en nummeraanduiding van de mosselbanken die in het kader van dit project in het jaar 2019 (oranje driehoekjes) of in de jaren ervoor (rode stippen) bezocht werden.

\subsection{Bepalen oppervlakte mosselbank}

De buitenste contour van de mosselbank worden volgens het TMAP-protocol (Brinkman et al., 2003), zie Figuur 2.2, in kaart gebracht. Hiervoor wordt met een gps in de hand langs de rand van de bank om de bank heen gelopen, waarbij de gelopen track wordt opgeslagen in gps-files. Er is gebruikgemaakt van Garmin-gps; 76, map76cx of 78 . Alleen wanneer de bodem voor $>5 \%$ met 
mosselbulten bedekt wordt, is deze bij de bank gerekend. Mosselbulten die verder dan 25 meter van de hoofdbank liggen, worden niet bij de bank gerekend. (Zie voor details Figuur 2.2 en Brinkman et al., 2003.)

De gps-files zijn in QGIS ingeladen om de definitieve contour te bepalen. Zowel de definitieve contour als de verschillende opwerkingsstappen zijn in verschillende shapefiles opgeslagen. Uit de definitieve contouren zijn de bankoppervlaktes berekend met QGIS en opgeslagen in de database. De ontwikkeling van de mosselbanken over de jaren wordt bekeken door de contouren van verschillende jaren van dezelfde bank in één figuur weer te geven.
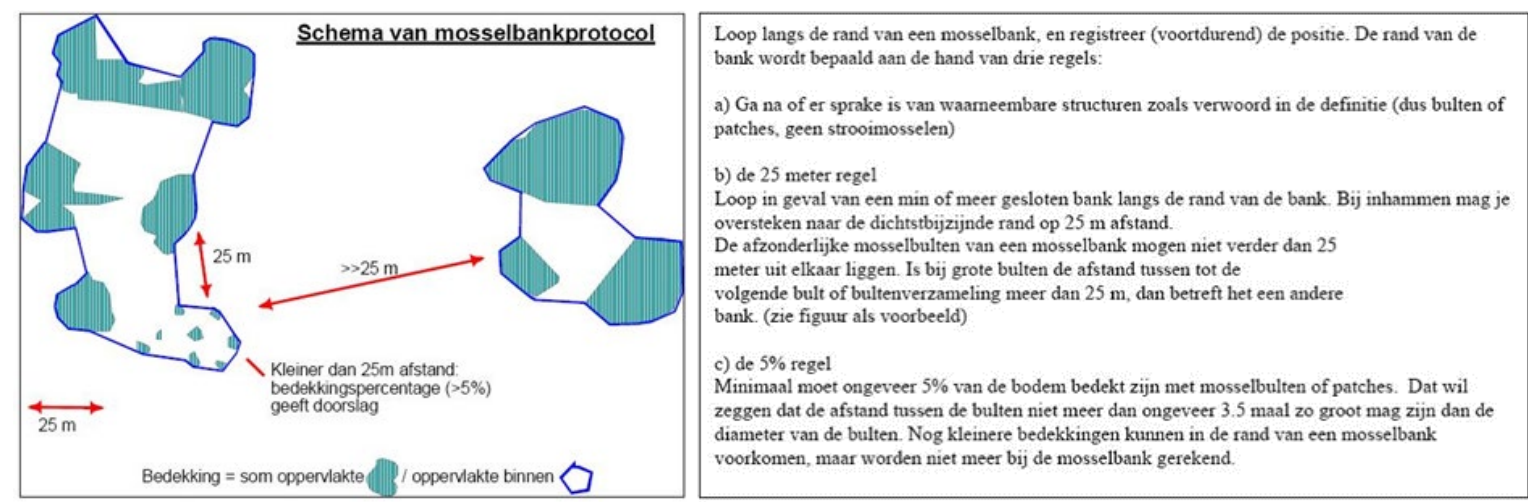

Figuur 2.2 TMAP-protocol voor het inlopen van mosselbanken (Brinkman et al., 2003).

\subsection{Bedekkingsmeting}

Om de mosselbedekking te bepalen, worden over de mosselbank raaien gelopen waarlangs het met mosselen bedekte oppervlak bepaald wordt. Hiervoor wordt voor iedere raai (en subraai, zie onder) zowel het totaalaantal als het aantal stappen dat op mosselen gezet is geteld en genoteerd. Door de gemiddelde bedekking (\%) uit te rekenen, kan het bankoppervlak verdeeld worden in een deel dat met mosselen bedekt is en een deel dat uit open plekken bestaat. In onderstaande paragrafen wordt de gevolgde procedure voor het bepalen van de mosselbedekking in detail beschreven.

\subsubsection{Raaien en subraaien}

De raai loopt van de rand van de mosselbank in een rechte lijn tot de tegenoverliggende rand van de mosselbank. Bij voorkeur wordt gebruikgemaakt van de in dat jaar en volgens het TMAP-protocol ingelopen contour van de bank. Wanneer deze nog niet aanwezig is, wordt de rand van de bank ter plekke bepaald op basis van het TMAP-protocol. Binnen deze raai worden subraaien genoteerd van elk 50 stappen om zodoende een gedetailleerder beeld van de bedekking te verkrijgen. Bij het startpunt en aan het eind van elke subraai wordt in het gps een waypoint (locatiemarkering) gemaakt. Bij het eindpunt van de raai (dus de rand van de mosselbank) wordt altijd een waypoint gemaakt, ook al zijn de 50 stappen nog niet voltooid. In dat geval wordt het werkelijke aantal gemaakte stappen genoteerd (Figuur 2.3a). Op het formulier moet duidelijk worden aangegeven wat de waypoints van de start en het einde van de totale raai zijn. Waypoints voor opmerkingen (oesters etc.) moeten apart gemaakt worden en duidelijk aangegeven worden in het formulier als niet behorend tot de (sub)raaien.

Wanneer zich een groot, open stuk (gat groter dan 50 stappen) in de mosselbank bevindt waar de raai doorheen loopt, dient de subraai te stoppen op de rand van het gat, zie Figuur 2.3b. Hier wordt weer een waypoint gemaakt. In het gat wordt een nieuwe subraai gestart. Deze subraai loopt helemaal door tot het eind van het gat (ook wanneer dit meer is dan 50 stappen), waarna weer een waypoint wordt gemaakt. Op het formulier wordt duidelijk aangegeven dat het hier om een gat in de mosselbank gaat. $\mathrm{Na}$ het gat wordt weer verder gelopen met subraaien totdat de raai is voltooid (Figuur 2.3b). Wanneer het gat kleiner is dan 50 stappen worden er waypoints gemaakt om de randen van het gat aan te 
geven en een aantekening gemaakt op het formulier betreffende dit gat. Er hoeft geen nieuwe subraai gestart te worden. Inhammen die volgens het TMAP-protocol onderdeel uitmaken van de bank (dus afstand kleiner dan $25 \mathrm{~m}$ ) worden net zo behandeld als een gat (Figuur 2.3c). Wanneer de inham niet binnen de definitie van een mosselbank valt (ingang $>25 \mathrm{~m}$ ), dient de raai afgesloten te worden bij de rand van de inham. Er wordt in dezelfde lijn als de raai door de inham gelopen totdat de mosselbank weer begint (Figuur 2.3d).

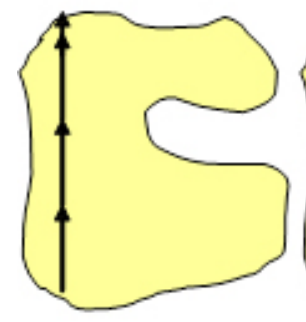

A. eind raai

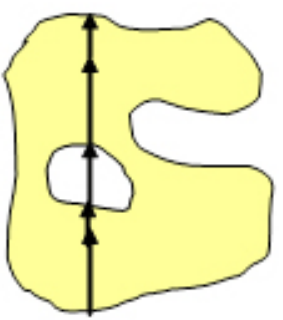

B. gat in mosselbank $>50$ stappen

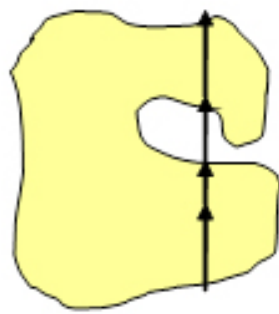

C. inham behorend tot Mosselb ank opening $<25 \mathrm{~m}$.

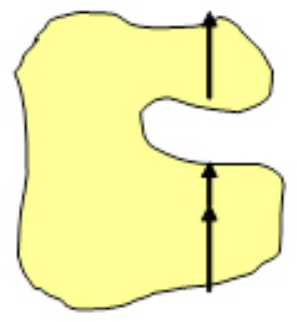

D. inham (ing ang $>25 \mathrm{~m}$ )

Figuur 2.3 Protocol voor het lopen en markeren van raaien en subraaien. Met de pijltjes worden waypoints (locatiemarkering in het gps) weergegeven, na 50 stappen of aan einde bank, begin of einde gat dan wel inham. Figuur $A$ geeft de situatie weer voor een raai zonder inham of gat, Figuur $B$ geeft de situatie weer voor een gat $>50$ stappen, Figuur $C$ een raai met een inham die bij de bank hoort (<25), en Figuur $D$ een inham die niet bij de bank hoort $>25 m$.

\subsubsection{Verdeling van de raaien}

De raaien worden zigzag, zo veel mogelijk in een hoofdrichting, over de mosselbank gelopen zodat de gehele mosselbank zo veel mogelijk gedekt wordt (Figuur 2.4). De hoeveelheid beschikbare tijd bepaalt de schaal van deze dekking: wanneer er veel tijd is, liggen de raaien dicht bij elkaar (Figuur 2.4A), is er weinig tijd beschikbaar, dan liggen de raaien ruimer verdeeld (Figuur 2.4B).
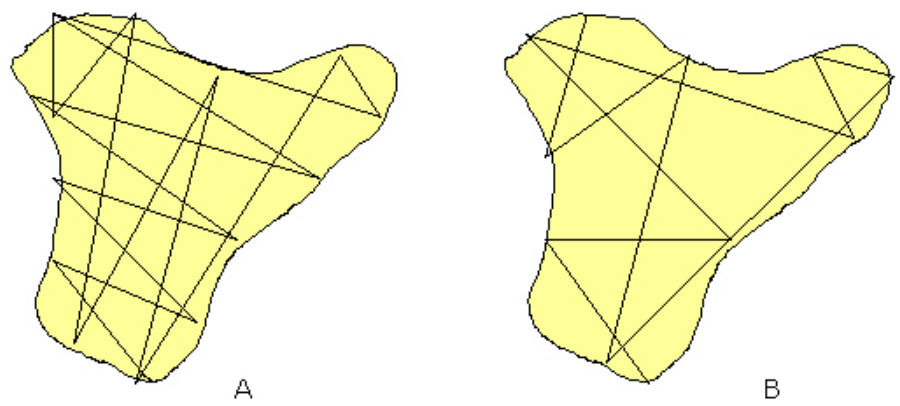

Figuur 2.4 Verdeling raaien over mosselbank. In Figuur A worden de raaien schematisch weergegeven in een situatie waarbij veel tijd is en de verschillende raaien dicht op elkaar liggen. In Figuur B wordt de ligging van de raaien schematisch weergegeven in een situatie met weinig tijd. In dat geval liggen de raaien wat verder uit elkaar, maar wordt alsnog de gehele bank bestreken. 


\subsubsection{Score van de mosselbedekking langs de raaien}

Per subraai wordt op het formulier aangegeven hoeveel keer er, van de 50 subraaistappen, op mosselen gestapt wordt. Dit wordt bijgehouden met een handteller. Voor alle stappen geldt dat als de voet op een mossel komt, deze stap als mosselstap telt (ongeacht of dit 1 mossel is of 10 mosselen zijn). Het bedekkingspercentage wordt vervolgens berekend uit het aantal mosselstappen ten opzichte van het totaal aan stappen.

Op de raaien wordt de aanwezigheid van oesters geschat door de oester- en mosselbedekking visueel in te schatten en de zgn. 'oesterscore' ( $0 \mathrm{t} / \mathrm{m} \mathrm{4}$ ) te noteren op het formulier. Hierbij worden vijf categorieën onderscheiden, zie (Tabel 2.1). Aan het eind van elke raai wordt een beschrijving gegeven (o.a. flora en fauna (zoals zeesla of kokkels)) van de gelopen raai.

Tabel 2.1 De verhouding tussen de mossel- en oesterbedekking behorend bij de oesterscores $0 t / m 4$.

\begin{tabular}{llll} 
Score & Omschrijing & Oester & Mossel \\
0 & Geen & $0 \%$ & $100 \%$ \\
\hline 1 & Weinig & $0-20 \%$ & $80-100 \%$ \\
\hline 2 & Matig & $20-50 \%$ & $50-80 \%$ \\
\hline 4 & Veel & $50-80 \%$ & $20-50 \%$ \\
\hline
\end{tabular}

\subsection{Lengte-frequentieverdeling en samenstelling}

Op elke mosselbank worden tussen de twee en zes monsters genomen om informatie te verkrijgen over de lengte-frequentieverdeling van de levende mosselen en lege mosselschelpen en over de aanwezigheid van andere schelpdieren en algen. In Tabel 2.2 wordt het aantal monsters dat per bank en per jaar genomen is, weergegeven.

Tabel 2.2 Aantal monsters per mosselbank per jaar.

\begin{tabular}{|c|c|c|c|c|c|c|c|c|c|c|c|c|c|c|}
\hline & 101 & 502 & 503 & 603 & 606 & 607 & 640 & 703 & 710 & 726 & 727 & 734 & 735 & 736 \\
\hline 1995 & 1 & 1 & & & & & & & & & & & & \\
\hline 1996 & 4 & 2 & & & & & & & & & & & & \\
\hline 1998 & 5 & 3 & 5 & 5 & & & & & & & & & & \\
\hline 1999 & 5 & 5 & 5 & 5 & & & & & & & & & & \\
\hline 2002 & & 6 & & 5 & & & & & & & & & & \\
\hline 2003 & & 5 & 5 & 5 & 5 & 5 & & 5 & & & & & & \\
\hline 2004 & & 5 & 5 & 7 & 6 & 5 & & 5 & & & & & & \\
\hline 2005 & & 5 & 5 & 6 & 5 & 5 & & 5 & & & & & & \\
\hline 2010 & & 5 & 5 & 5 & & & & 5 & 5 & 2 & & & 4 & 5 \\
\hline 2011 & & 5 & 5 & 5 & & & & 5 & 5 & 2 & & & 2 & 5 \\
\hline 2012 & & 5 & 5 & 5 & & & & 5 & 5 & & & & & 5 \\
\hline 2013 & & 5 & 5 & 5 & & & & 5 & 5 & & & & & 5 \\
\hline 2014 & & 5 & 5 & 5 & & & & 5 & 5 & & & & & 5 \\
\hline 2015 & & 5 & 5 & 5 & & 4 & & 5 & 5 & & & & & 5 \\
\hline 2016 & & 5 & 5 & 5 & & & & 2 & 5 & & & & & 5 \\
\hline 2017 & & 5 & 5 & 5 & & 5 & & 2 & 5 & & & & & 3 \\
\hline 2018 & & 5 & 5 & 5 & & & 4 & & 5 & & & & & 5 \\
\hline
\end{tabular}


De monsters worden jaarlijks op nagenoeg dezelfde locatie genomen, dat wil zeggen zo mogelijk binnen dezelfde mosselpatch. Op de locatie wordt een representatief deel van de mosselbank uitgekozen waar het monster wordt genomen. Het monster wordt genomen met behulp van een frame met een dimensie $(\mathrm{cm})$ van 16 (b) $\times 32$ (I) $\times 10$ (d) die in de mosselbank gedrukt wordt, totdat de bovenkant gelijk ligt met het mosseloppervlak. De toplaag van $10 \mathrm{~cm}$ wordt uit het vierkant geschraapt en in een zeef met een maaswijdte van $1 \mathrm{~mm}$ voorzichtig uitgespoeld. De exacte monsterlocatie wordt gemarkeerd met een waypoint. Het monster wordt verzameld in een plastic zak, gelabeld en naar het laboratorium vervoerd voor analyse.

In het laboratorium worden de monsters nogmaals goed gespoeld en gezeefd (over een zeef met maaswijdte van 5 en $1 \mathrm{~mm}$ ). Het monster wordt hierdoor onderverdeeld in twee delen: een grove en fijne fractie. Beide delen worden gewogen (afgerond tot hele grammen). Hierna worden uit beide deelmonsters alle levende schelpdieren (incl. alikruiken), levende algen, krabben en lege hele mosselschelpen (zowel de nog aan elkaar vastzittende kleppen, zgn. 'doubletten', als de losse kleppen) gehaald. Hierna wordt het restant van de grove en fijne fractie nogmaals gewogen. De pokken worden van de levende mosselen gescheiden en apart gewogen. De levende mosselen, de andere levende schelpdieren, de levende algen en de lege doubletten en lege losse mosselschelpen worden afzonderlijk gewogen. Ook van de andere levende schelpdieren worden de aantallen per soort op het formulier vermeld.

Hierna wordt de lengte (in $\mathrm{mm}$ ) gemeten van alle levende mosselen, de andere levende schelpdieren (excl. de alikruiken) en van de losse kleppen en doubletten van lege mosselschelpen. 



\section{Resultaten}

\subsection{Ontwikkeling contouren en oppervlakte}

Elk jaar zijn de contouren (= buitengrenzen van de bank) van de individuele mosselbanken nauwkeurig ingemeten. In Figuur $3.1 \mathrm{t} / \mathrm{m} 3.8$ worden voor de onderzochte banken de bankcontouren van een aantal bemonsteringsjaren weergegeven en worden 'mosselbankfrequentie'-kaarten getoond met daarin aangegeven het aantal jaren dat een gebied als mosselbank gekarteerd is. Naast de contouren van het jaar 2019 zijn, wanneer aanwezig, ook de contouren van het voorgaande bemonsteringsjaar (2018) en van de eerste opname weergegeven (jaartal verschilt per bank) om zowel de veranderingen ten opzichte van het afgelopen jaar als de verandering vanaf het eerste meetmoment inzichtelijk te maken. In Bijlage 1 wordt per bank de contour van ieder afzonderlijk jaar weergegeven. Het bankoppervlak is berekend aan de hand van deze contouren en wordt weergegeven in Figuur 3.9. Door gebruik te maken van informatie uit de bedekkingsraaien is het mogelijk de gemiddelde schelpdierbedekking te berekenen en daarmee het mosselbankoppervlak op te splitsen in een met mosselen (en oesters) bedekt deel en een open deel dat niet met mosselen of oesters bedekt is ( $=$ het totaaloppervlak aan open plekken tussen de mossel- en oesterpatches).
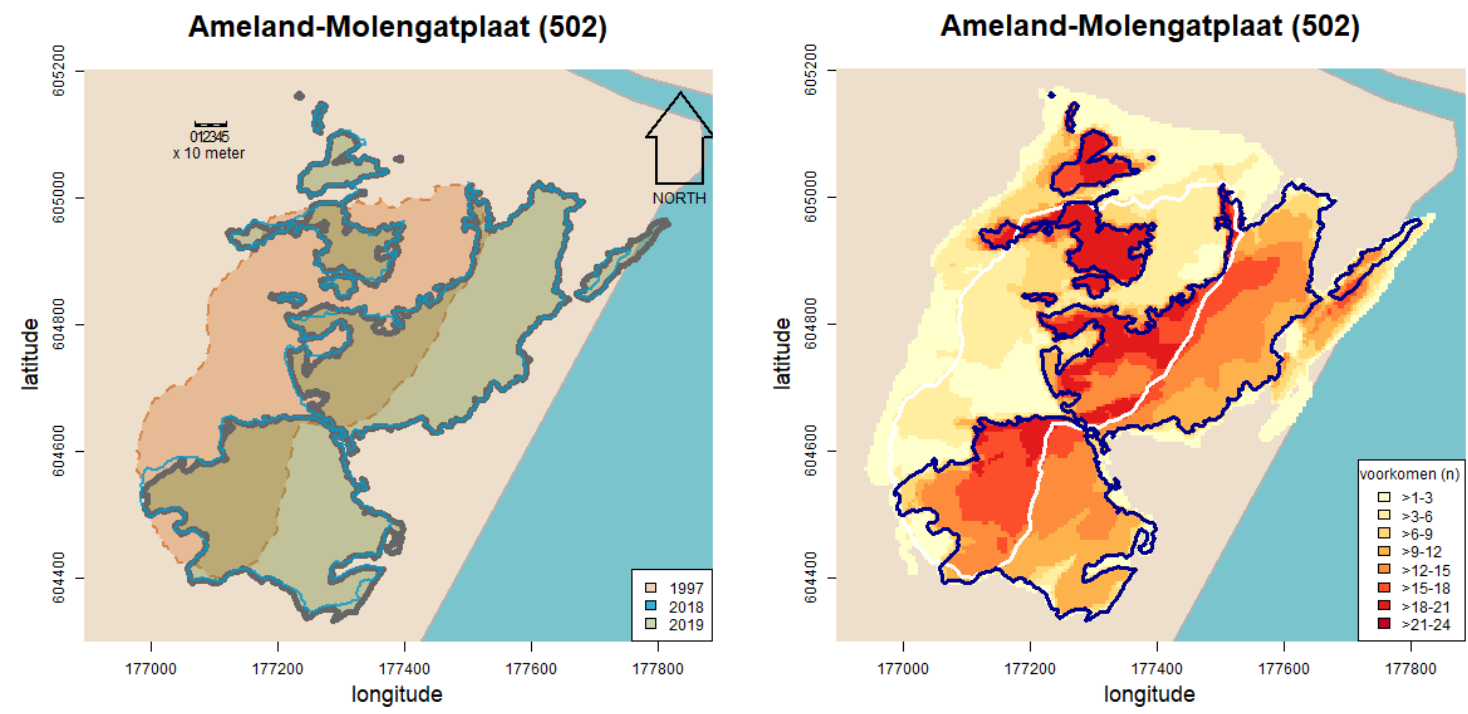

Figuur 3.1 Contouren van de mosselbank 502 (onder Ameland) voor verschillende jaren. In de linkerfiguur worden de contouren weergegeven zoals bepaald in de eerste meting (in 1997 en lichtbruin ingekleurd), zoals bepaald in 2019 (lichtgroen ingekleurd) en zoals bepaald in 2018 (lichtblauw omlijnd). In de rechterfiguur wordt op een raster van 5 bij 5 meter weergegeven hoe vaak de rastercellen zich binnen de mosselbank bevonden (hoe roder, hoe frequenter) voor de jaren dat de bank bezocht werd en er een contour beschikbaar was. In deze figuur wordt met een witte lijn de contour van de eerste meting weergegeven en met een donkerblauw doortrokken lijn de contour van de bank in 2019. De ligging van de geul (lichtblauw) komt uit een opname uit 2003 en is daarom indicatief voor de huidige situatie (de geul kan zich inmiddels verplaatst hebben). 

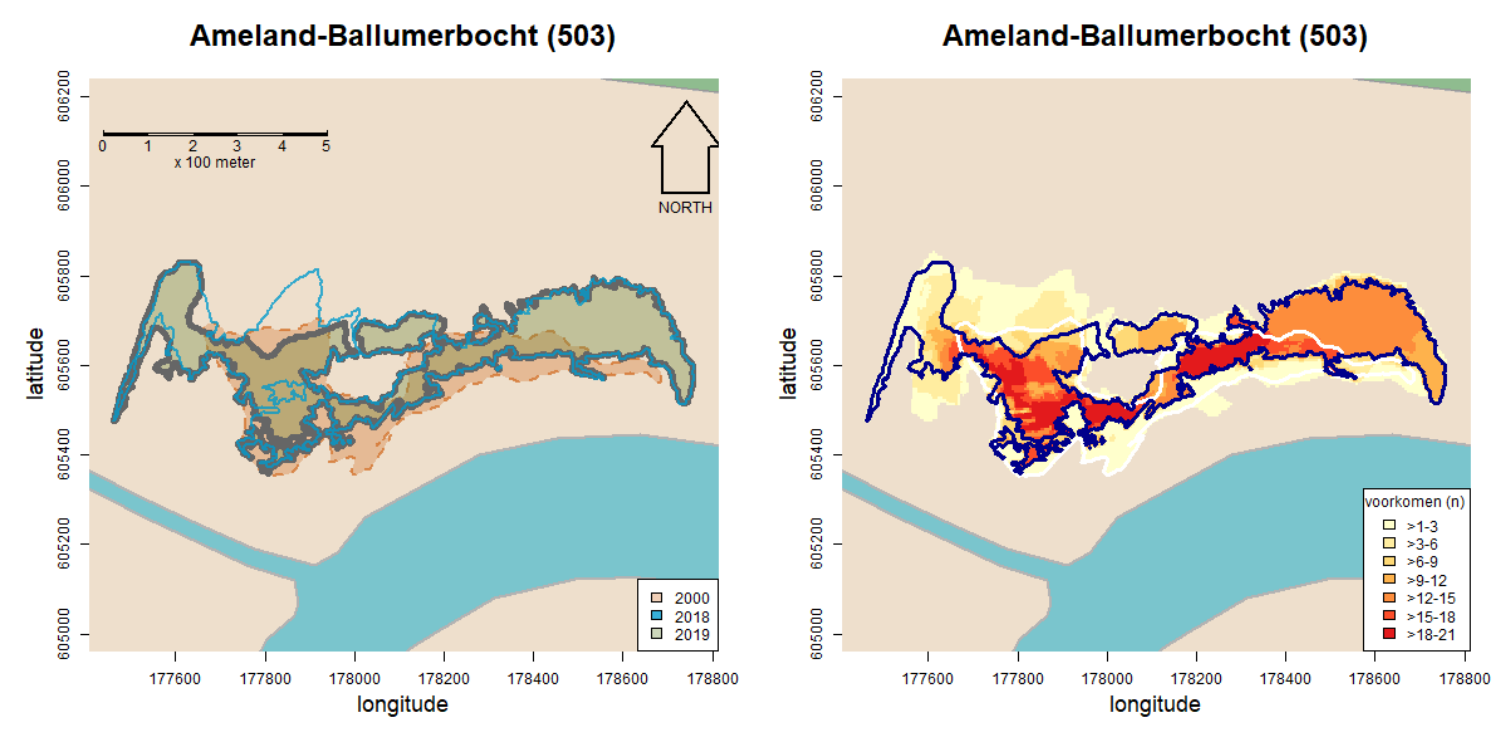

Figuur 3.2 Contouren van de mosselbank 503 (onder Ameland) voor verschillende jaren. In de linkerfiguur worden de contouren weergegeven zoals bepaald in de eerste meting (in 2000 en lichtbruin ingekleurd), zoals bepaald in 2019 (lichtgroen ingekleurd) en zoals bepaald in 2018 (lichtblauw omlijnd). In de rechterfiguur wordt op een raster van 5 bij 5 meter weergegeven hoe vaak de rastercellen zich binnen de mosselbank bevonden (hoe roder, hoe frequenter) voor de jaren dat de bank bezocht werd en er een contour beschikbaar was. In deze figuur wordt met een witte lijn de contour van de eerste meting weergegeven en met een donkerblauw doortrokken lijn de contour van de bank in 2019. De ligging van de geul (lichtblauw) komt uit een opname uit 2003 en is daarom indicatief voor de huidige situatie (de geul kan zich inmiddels verplaatst hebben).
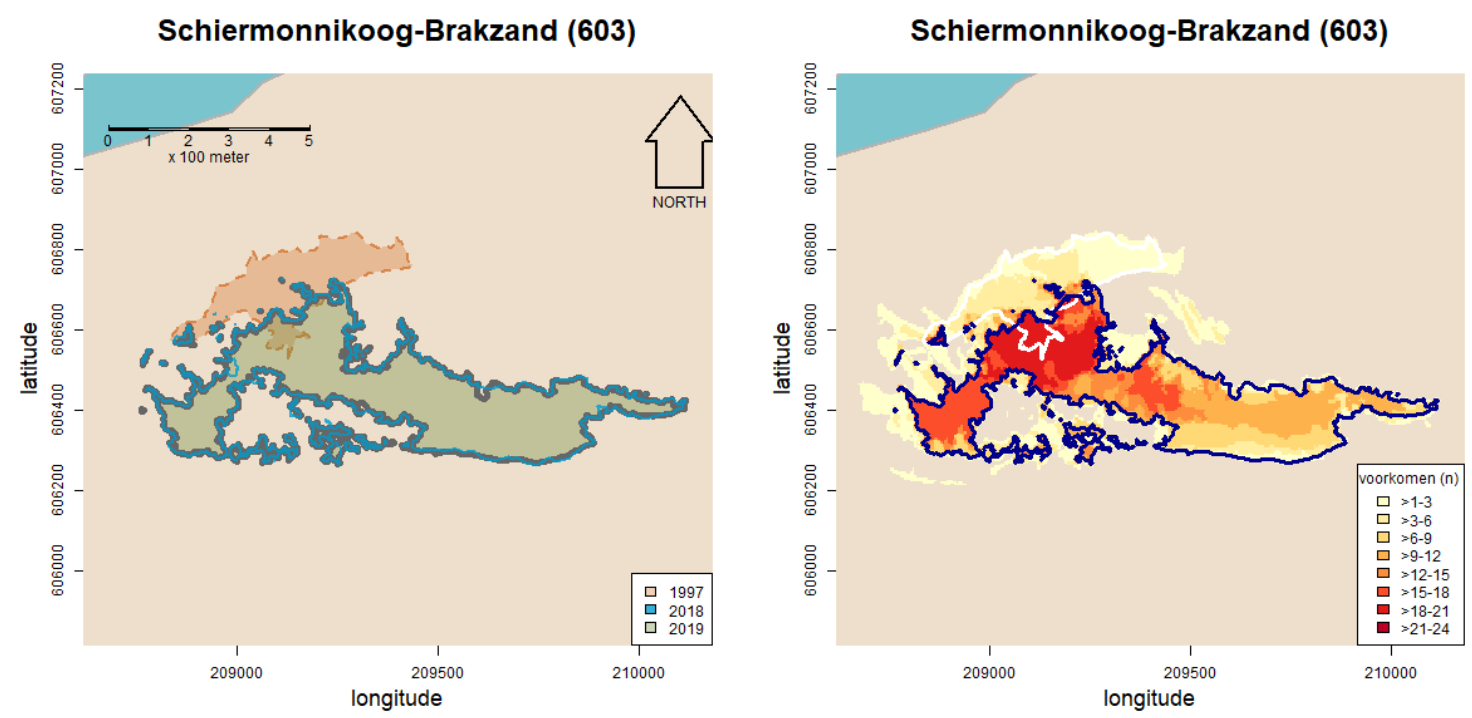

Figuur 3.3 Contouren van de mosselbank 603 (onder Schiermonnikoog) voor verschillende jaren. In de linkerfiguur worden de contouren weergegeven zoals bepaald in de eerste meting (in 1997 en lichtbruin ingekleurd), zoals bepaald in 2019 (lichtgroen ingekleurd) en zoals bepaald in 2018 (lichtblauw omlijnd). In de rechterfiguur wordt op een raster van 5 bij 5 meter weergegeven hoe vaak de rastercellen zich binnen de mosselbank bevonden (hoe roder, hoe frequenter) voor de jaren dat de bank bezocht werd en er een contour beschikbaar was. In deze figuur wordt met een witte lijn de contour van de eerste meting weergegeven en met een donkerblauw doortrokken lijn de contour van de bank in 2019. De ligging van de geul (lichtblauw) komt uit een opname uit 2003 en is daarom indicatief voor de huidige situatie (de geul kan zich inmiddels verplaatst hebben). 

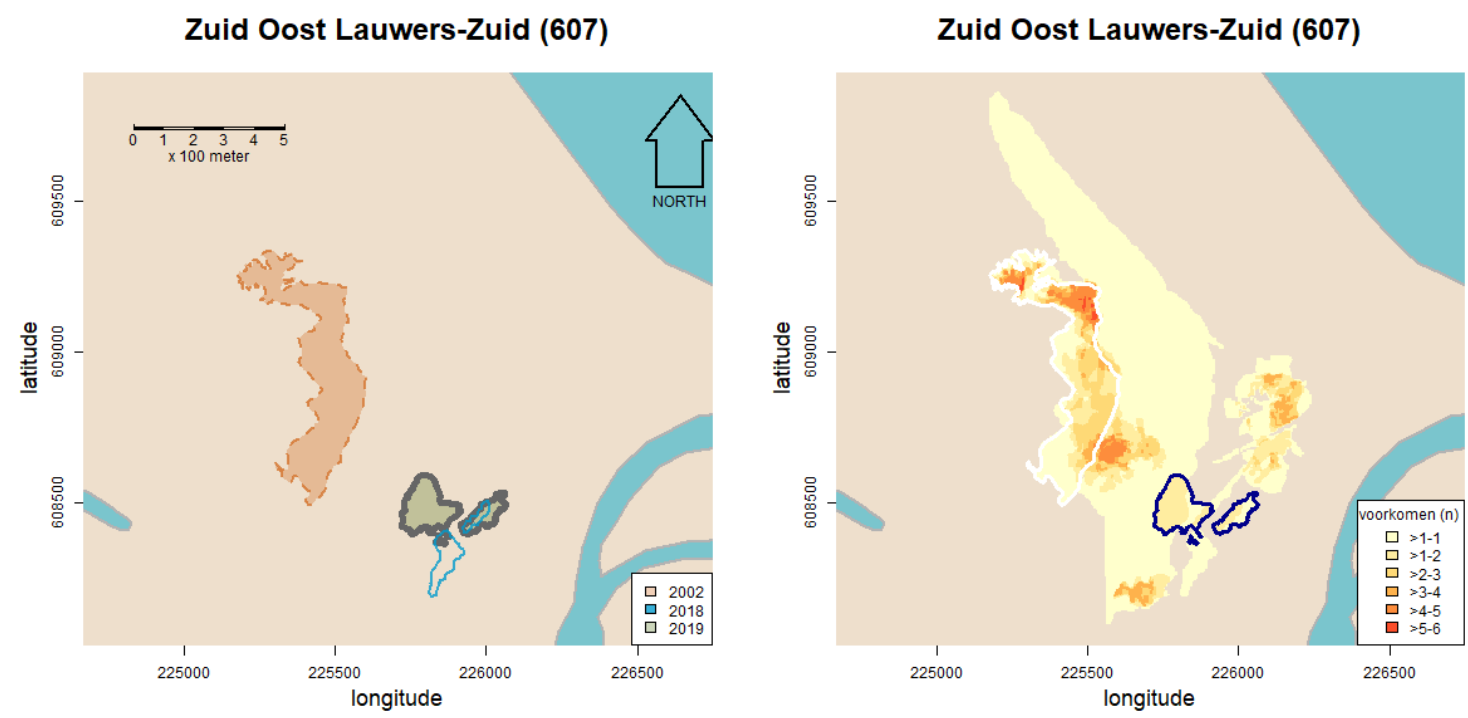

Figuur 3.4 Contouren van de mosselbank 607 (onder Rottumerplaat) voor verschillende jaren. In de linkerfiguur worden de contouren weergegeven zoals bepaald in de eerste meting (in 2002 en lichtbruin ingekleurd), zoals bepaald in 2019 (lichtgroen ingekleurd) en zoals bepaald in 2018 (lichtblauw omlijnd). In de rechterfiguur wordt op een raster van 5 bij 5 meter weergegeven hoe vaak de rastercellen zich binnen de mosselbank bevonden (hoe roder, hoe frequenter) voor de jaren dat de bank bezocht werd en er een contour beschikbaar was. In deze figuur wordt met een witte lijn de contour van de eerste meting weergegeven en met een donkerblauw doortrokken lijn de contour van de bank in 2019. De ligging van de geul (lichtblauw) komt uit een opname uit 2003 en is daarom indicatief voor de huidige situatie (de geul kan zich inmiddels verplaatst hebben).

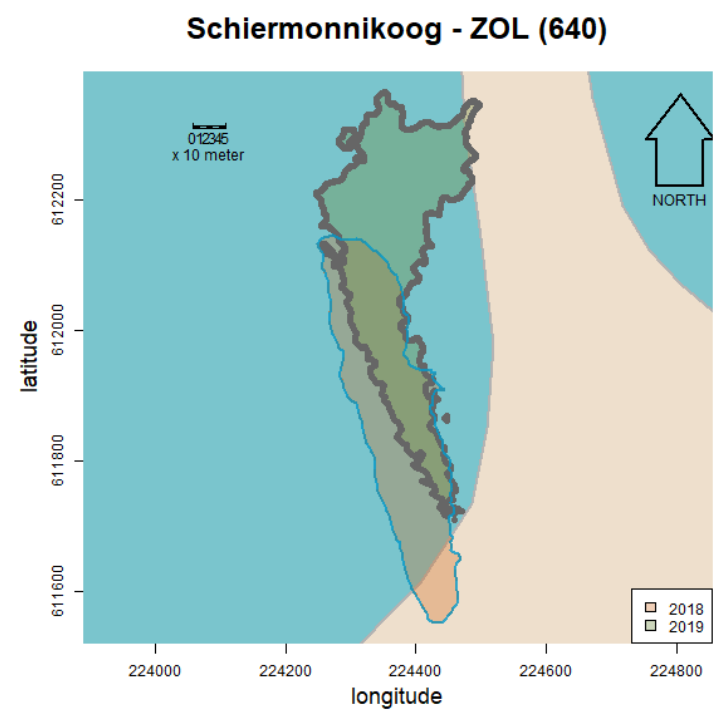

Figuur 3.5 Contour van de in 2018 nieuwgevormde mosselbank 640 (onder Rottumerplaat) voor 2018 en 2019. In de figuur worden de contouren weergegeven zoals bepaald in de eerste meting (in 2018 en lichtbruin ingekleurd) en zoals bepaald in 2019 (lichtgroen ingekleurd). De ligging van de geul (lichtblauw) komt uit een opname uit 2003 en is daarom indicatief voor de huidige situatie (de geul kan zich inmiddels verplaatst hebben). 

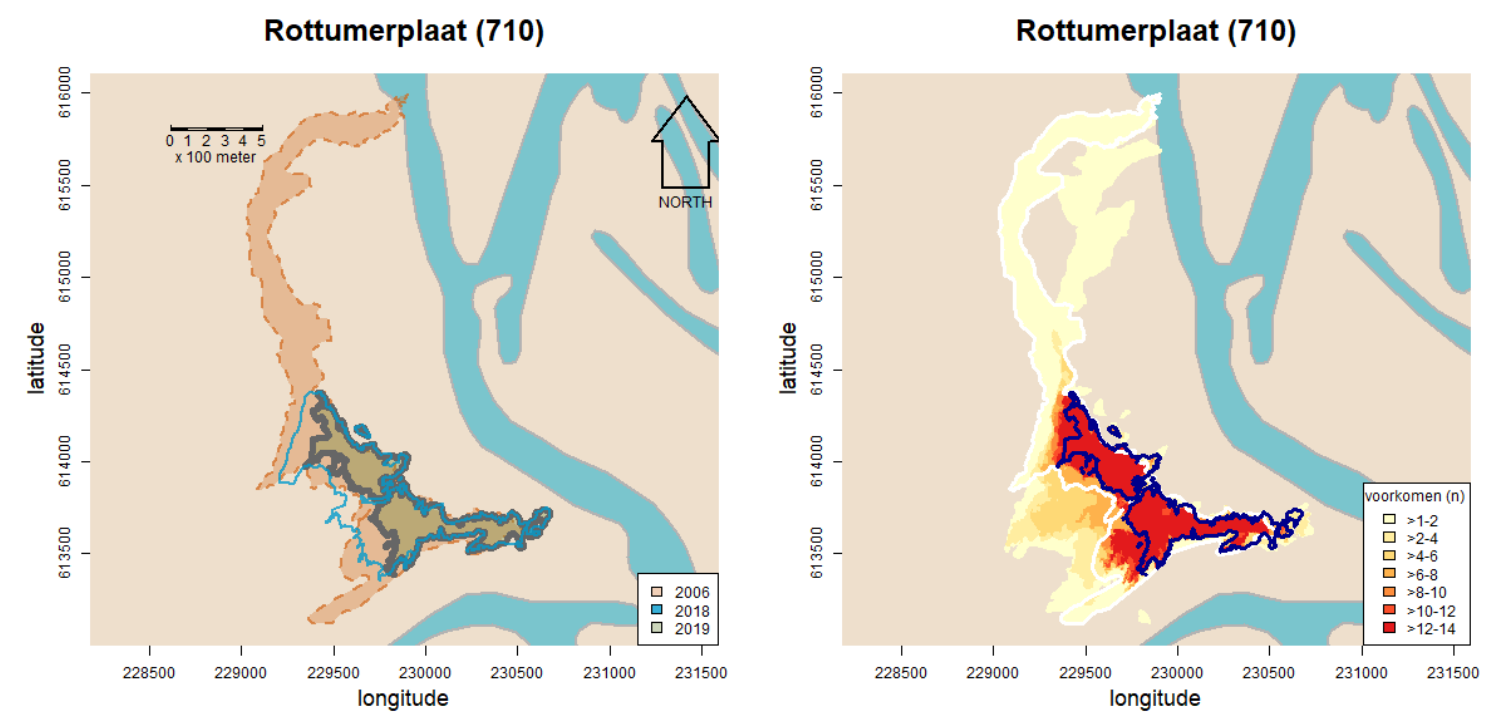

Figuur 3.6 Contouren van de mosselbank 710 (onder Rottumerplaat) voor verschillende jaren. In de linkerfiguur worden de contouren weergegeven zoals bepaald in de eerste meting (in het jaar 2005 en lichtbruin ingekleurd), zoals bepaald in 2019 (lichtgroen ingekleurd) en zoals bepaald in 2018 (lichtblauw omlijnd). In de rechterfiguur wordt op een raster van 5 bij 5 meter weergegeven hoe vaak de rastercellen zich binnen de mosselbank bevonden (hoe roder, hoe frequenter) voor de jaren dat de bank bezocht werd en er een contour beschikbaar was. In deze figuur wordt met een witte lijn de contour van de eerste meting weergegeven en met een donkerblauw doortrokken lijn de contour van de bank in 2019. De ligging van de geul (lichtblauw) komt uit een opname uit 2003 en is daarom indicatief voor de huidige situatie (de geul kan zich inmiddels verplaatst hebben).

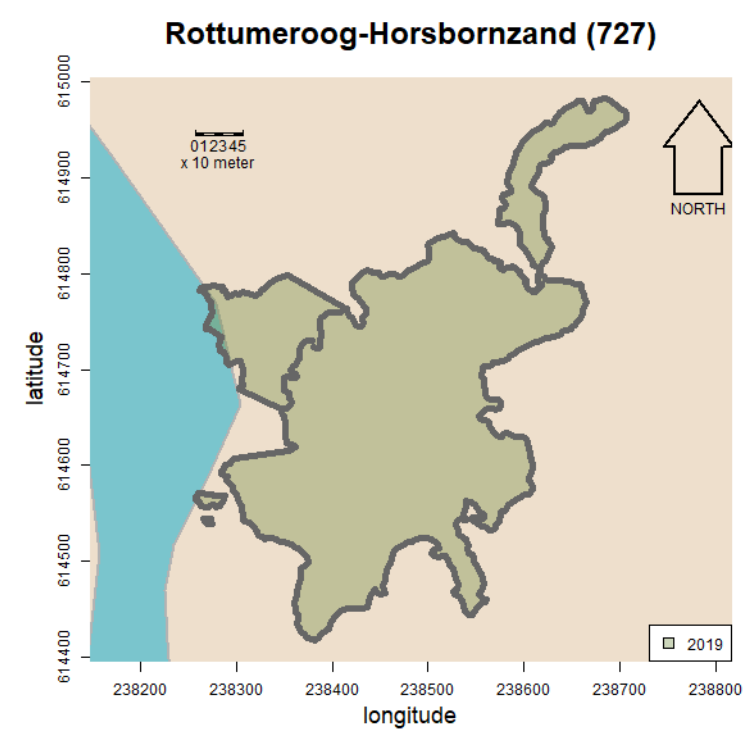

Figuur 3.7 Contour van de mosselbank 727 (Rottumeroog-Horsbornzand) voor 2019, de eerste meting van deze bank. De ligging van de geul (lichtblauw) komt uit een opname uit 2003 en is daarom indicatief voor de huidige situatie (de geul kan zich inmiddels verplaatst hebben). 

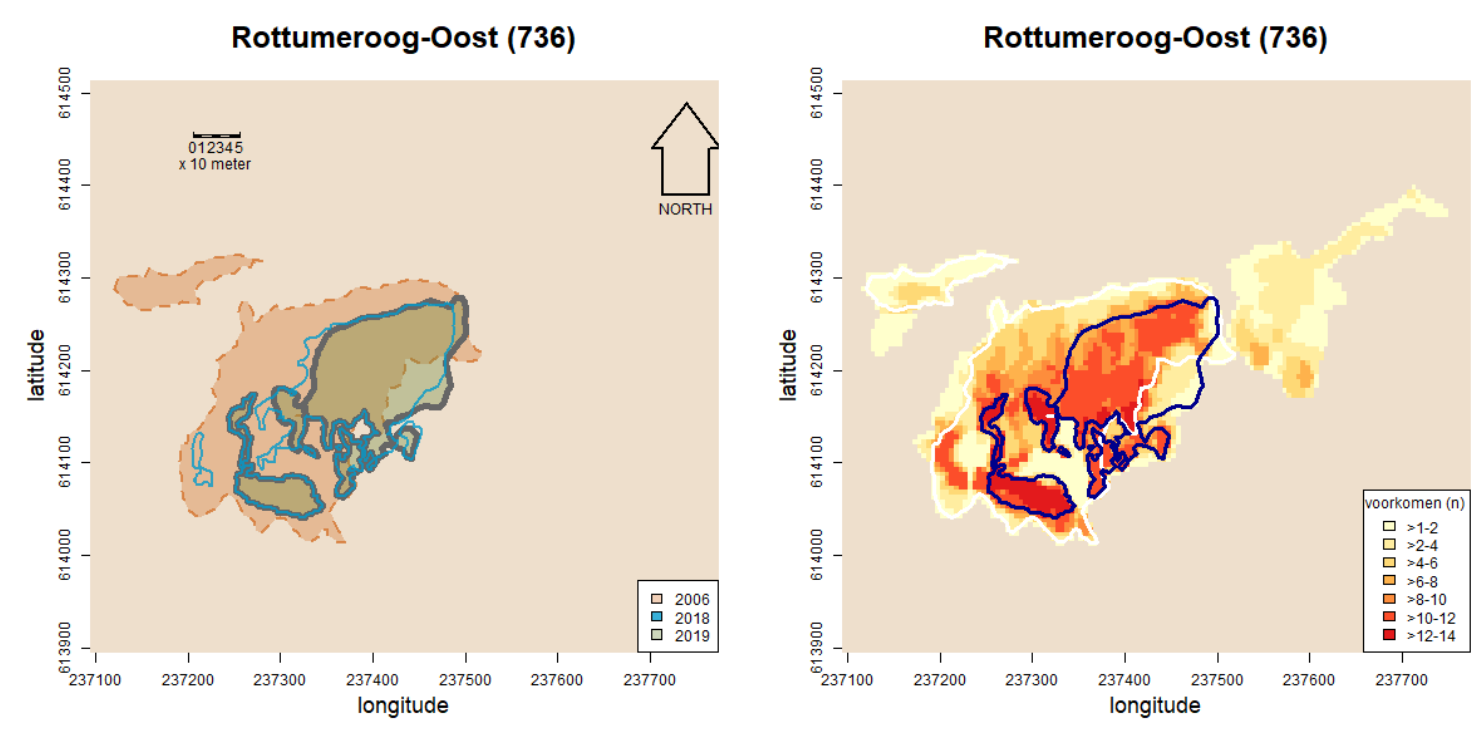

Figuur 3.8 Contouren van de mosselbank 736 (onder Rottumeroog) voor verschillende jaren. In de linkerfiguur worden de contouren weergegeven zoals bepaald in de eerste meting (in 2005 en lichtbruin ingekleurd), zoals bepaald in 2019 (lichtgroen ingekleurd) en zoals bepaald in 2018 (lichtblauw omlijnd). In de rechterfiguur wordt op een raster van 5 bij 5 meter weergegeven hoe vaak de rastercellen zich binnen de mosselbank bevonden (hoe roder, hoe frequenter) voor de jaren dat de bank bezocht werd en er een contour beschikbaar was. In deze figuur wordt met een witte lijn de contour van de eerste meting weergegeven en met een donkerblauw doortrokken lijn de contour van de bank in 2018. Aan de zuidoostkant van de bank bevindt zich een geul.

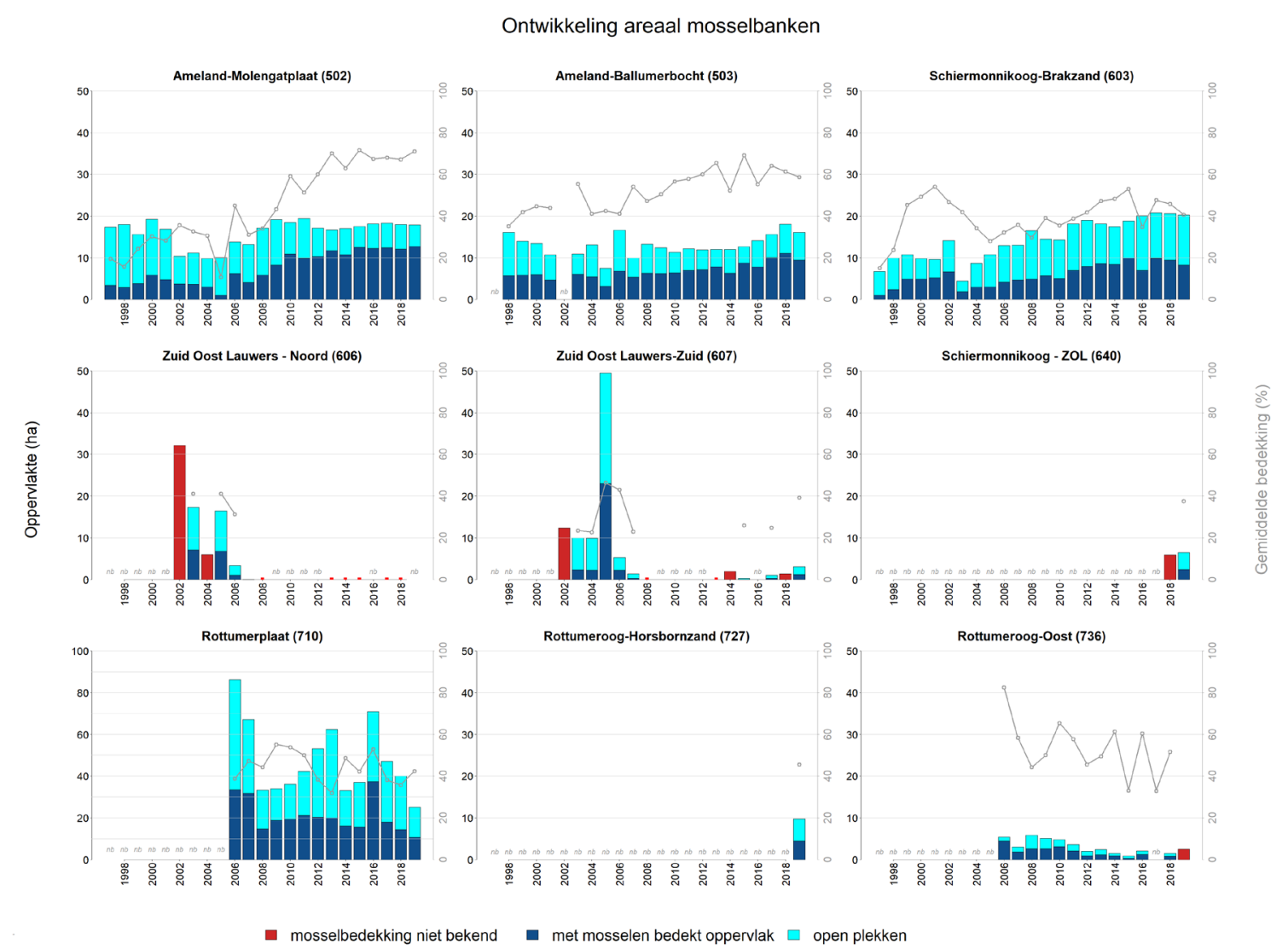

Figuur 3.9 Ontwikkeling van de bankoppervlakte (in hectaren en weergegeven met staven, uitgezet ten opzichte van de linker $y$-as) en de gemiddelde mosselbedekking (in procenten en weergegeven met een grijze, gekleurde lijn, uitgezet ten opzichte van de rechter $y$-as) voor de banken 502, 503, 603, 606, 607, 640, 710, 727 en 736 in de periode 1997 t/m 2019. De hoogte van de balk (donkeren lichtblauwe deel) geeft de totale bankoppervlakte weer, het donkerblauwe deel het met mosselen bedekte oppervlak en het lichtblauwe deel het areaal open plekken. Met rode balken wordt het bankoppervlak weergegeven voor situaties waarin de bedekking niet bekend was. Wanneer een bank wel bezocht werd maar niet aanwezig was, is dit met een rode stip aangegeven; wanneer een bank niet bezocht werd, is dit met ' $n b^{\prime}$ ' aangegeven. 
De ligging, de contour, het bankoppervlak en het met mosselen bedekte oppervlak van de banken 502 (Ameland-Molengatplaat), 503 (Ameland-Ballumerbocht), 603 (Schiermonnikoog-Brakzand) en 736 (Rottumeroog-oost) zijn in het jaar 2019 nagenoeg onveranderd gebleven ten opzichte van de jaren ervoor, zie de Figuren 3.1, 3.2, 3.3, 3.8, 3.9 en Figuren in Bijlage 1. De subtiele veranderingen die opgetreden zijn, bestaan er wat betreft bank 502 uit dat het zuidoostelijke deel van de bank, gelegen op een schelpenbank, wat uitgewaaid is en daarmee een groter oppervlak beslaat dan in 2018. De veranderingen voor bank 503 (Ameland-Ballumerbocht) bestaan eruit dat een gebied gelegen aan de noordelijke zijde van de bank en met lage mosselbedekking verdwenen is, waardoor het bankoppervlak afgenomen is in 2019. In bank 603 hebben zich geen noemenswaardige veranderingen voorgedaan. Een groot deel van het oppervlak van deze banken (502, 503 en 603) bevindt zich momenteel in het gebied waar, gedurende dit onderzoek, frequent mosselbanken gevonden zijn, zie hiervoor de oranje- en roodgekleurde vlakken in Figuur 3.1, 3.2 en 3.3. De ligging en het bankoppervlak van mosselbank 736 zijn in 2019 ook niet veel veranderd. Het noordoostelijke deel van de bank, dat in 2018 opnieuw ontstaan is en volledig uit mosselzaad bestond, is goed blijven liggen en weinig veranderd in 2018. Dit deel is iets verwaaid naar het noordoosten, waardoor het bankoppervlak ook iets toegenomen is (zie Figuur 3.8 en 3.9).

De veranderingen voor de mosselbanken 607 (Zuid Oost Lauwers-Zuid), 640 (Schiermonnikoog ZOL) en 710 (Rottumerplaat) zijn in 2019 ten opzichte van het jaar 2018 wat groter dan voor de banken 502, 503, 603 en 736. In 2018 bestond mosselbank 607 geheel uit mosselzaad. Deze mosselzaadbank heeft de winterperiode overleeft en is in 2019 weer aangetroffen. Mosselzaadbulten zijn nog niet stevig verankerd in de ondergrond en kunnen wat gemakkelijker verplaatst worden door eb- en vloedstromingen in vergelijking met oudere mosselbanken. Dit verklaart daarom mogelijk dat delen van de mosselzaadbank uit 2018 in 2019 verplaatst zijn, zie Figuur 3.4. Het meest zuidelijk gelegen deel in 2018 is opgeschoven naar het noorden en ligt in 2019 aan de noordelijke zijde van een kleine geul, zie Figuur 3.10. Het oostelijk gelegen deel is in 2019 nog wat verder opgeschoven naar het oosten en bevindt zich in 2019 deels tussen twee geultjes, zie Figuur 3.4 en 3.10. Rondom de twee kleine bankdelen gelegen in het zuiden en aan de oostelijke zijde van de oostelijk gelegen mosselbank zijn in 2019 strooimosselen (bedekking < 5\%) aangetroffen. Omdat dergelijk lage bedekkingspercentages niet tot een mosselbank gerekend worden, zijn deze delen niet weergegeven in Figuur 3.4 en 3.10. Het totale bankoppervlak is in 2019 ongeveer verdubbeld: van 1.4 hectare in 2018 naar 3 hectare in 2019 (zie Figuur 3.9).

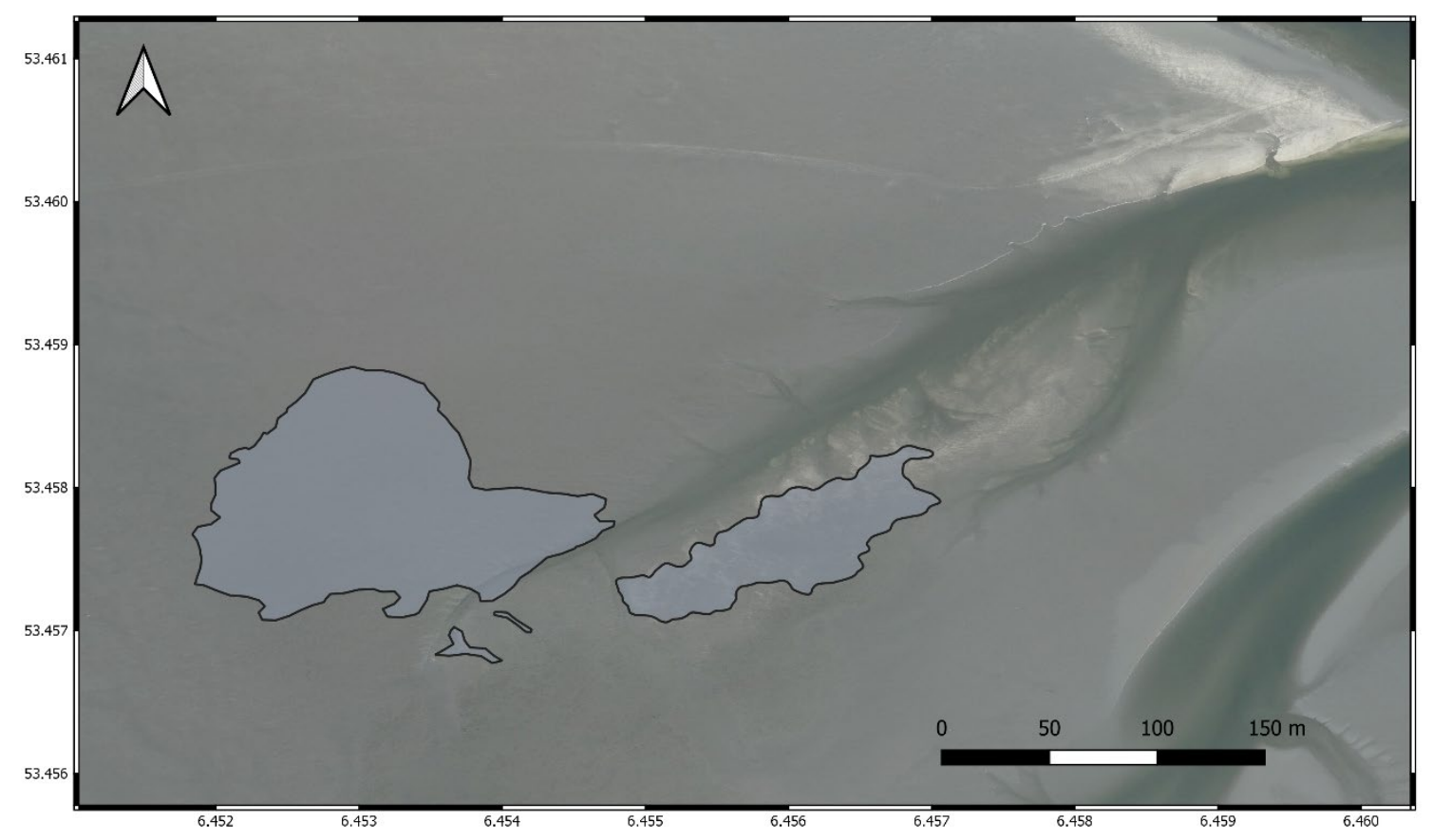

Figuur 3.10 Contour van de mosselbank 607 (Zuid Oost Lauwers-Zuid) in 2019 geprojecteerd op een satellietkaart van het jaar 2018. 
De in 2018 nieuwgevormde bank 640 (Zuid Oost Lauwers-Zuid) is in 2019 in noordelijke richting opgeschoven, zie Figuur 3.5. Zowel de noordelijke als zuidelijke zijde van de bank heeft zich hierbij in 2019 ongeveer 200 meter verplaatst. In het noorden is de bank wat breder geworden en een groot deel van de bank, ongeveer de helft, bevindt zich in 2019 buiten het gebied dat in 2018 tot de bank behoorde toen deze ontstond. De bank is door deze verschuivingen iets in oppervlak toegenomen.

Veranderingen in bank 710 hebben zich voornamelijk voltrokken aan de westelijke kant van deze bank. Dit deel van de bank, die eerst in de jaren 2011 en 2012 gevormd is en later nogmaals in 2016, verdwijnt sinds 2016 elk jaar. Net als in 2018 is ook in 2019 wederom een stuk van de mosselbank verdwenen op deze plek. Ook in het noorden is de bank een stuk kleiner geworden. Als gevolg hiervan nam ook het bankoppervlak af: van 70 hectare in 2016 tot 40 hectare in 2018 en 25 hectare in 2019, zoals te zien is in Figuur 3.6 en Bijlage 1. Momenteel bevindt de zuidwestelijke rand van de mosselbank zich aan de oostelijke zijde van rand van de bank uit de eerste meting uit 2006, zie Figuur 3.6. Aan de overige randen van de bank is weinig veranderd. De bank bevindt zich in 2018 grotendeels in een gebied dat al sinds jaren ( $>10$ jaar) uit mosselbank bestaat en bewijst daarmee stabiel te zijn.

Mosselbank 606 (Zuidoost Lauwers - Noord) is, net als in 2018, niet teruggevonden in 2019.

De in 2018 nieuwgevormde mosselbank 727 (Rottumeroog - Hornsbornzand) is in 2018 eerst opgemerkt tijdens de terugtocht van de werkzaamheden aan bank 734 in 2018. In 2019 is de bank voor het eerst bemonsterd in het kader van dit programma. De bank beslaat een oppervlak van net geen 10 hectaren en bevindt zich op de wadplaat oostelijke van de geul Sparregat, zie Figuur 3.7 en 3.9. De mosselbedekking is in het noordoostelijk gelegen deel wat hoger dan in het zuidelijk en westelijk gelegen delen van de bank (zie Bijlage 1).

\subsection{Ontwikkeling mosselen en oesters}

In Figuur 3.11 worden de lengte-frequentiediagrammen weergegeven voor de mosselbanken 502, $503,603,607,640,710,727$ en 736 en voor de jaren dat deze bemonsterd werden. De biomassa van mosselen en oesters en het aandeel oesters die in de monsters werden gevonden op de onderzochte banken zijn weergegeven in Figuur 3.12. De oesterbedekking op de subraaien is weergegeven in Bijlage 3. Het gemiddelde aantal en de biomassa van mosselen en oesters in de vierkantmonsters zijn weergegeven in respectievelijk Bijlage 4 en 5. 

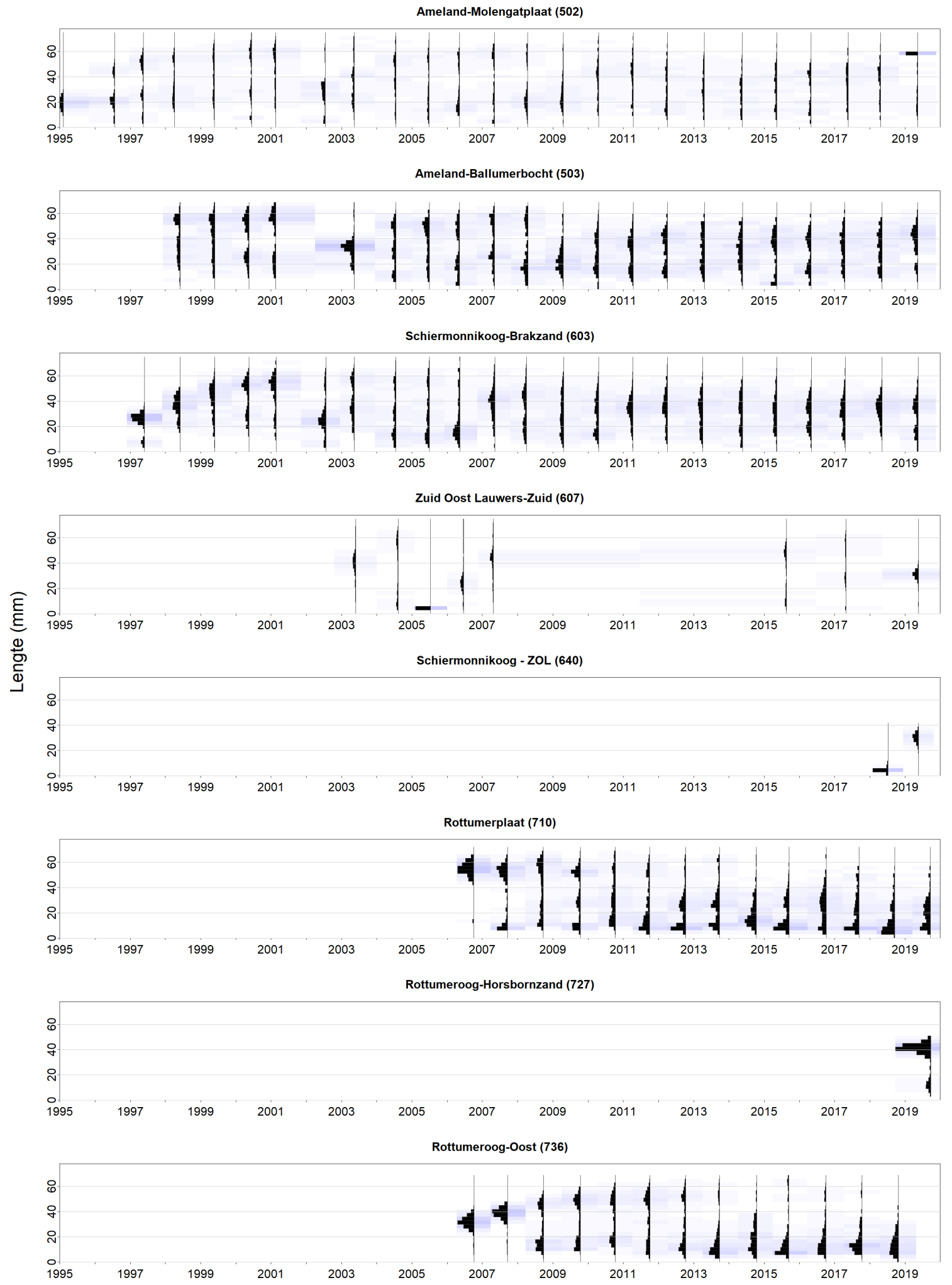

Figuur 3.11 Ontwikkeling van de lengtefrequentie (aantallen gestandaardiseerd naar 1000 mosselen en stapgrootte van $3 \mathrm{~mm}$ ) van de mosselpopulatie op de mosselbanken 502, 503, 603, 640, 710, 727, en 736 vanaf $1995 \mathrm{t} / \mathrm{m} 2019$.

In Figuur 3.11 is goed te zien hoe mosselen van het eerste cohort van de banken 603 en 736 zich in de opvolgende jaren ontwikkelen (groeien). Na ongeveer zes jaar lijkt het eerste cohort uitgegroeid te zijn, waarbij een lengte van ongeveer $60 \mathrm{~mm}$ bereikt is. Ook is goed te zien dat de banken 502 en 503 (onder Ameland), bank 607 (Zuid Oost Lauwers) en bank 710 (onder Rottumerplaat) ontstaan zijn 
enkele jaren voordat de eerste metingen uitgevoerd werden. Het prille begin van deze banken is niet gevolgd binnen dit programma; de eerste histogrammen voor deze banken pieken bij een lengteklasse van $>20 \mathrm{~mm}$ voor de eerste jaren.

Uit het lengte-frequentiediagram van bank 640 uit 2019 is te zien hoe het mosselzaad uit 2018 gegroeid is tot een lengte van ongeveer $35 \mathrm{~mm}$. Uit de lengtefrequentieverdelingen van 2019 voor deze bank kan geen tweede cohort ontdekt worden. Er zijn in 2018 geen metingen verricht aan mosselbank 727, maar de aanwezigheid van mosselzaad in het gebied is in 2018 wel visueel waargenomen (zie paragraaf 3.1). Het lengte-frequentiediagram van bank 727 in 2019 duidt op de aanwezigheid van twee jaarklassen/cohorten. Het eerste cohort bestaat dan vermoedelijk uit mosselzaad van 2018 dat gegroeid is tot ongeveer $40 \mathrm{~mm}$ lang in 2019 . Het tweede cohort bestaat uit mosselen met een lengte van ongeveer $10 \mathrm{~mm}$, en bestaat vermoedelijk uit mosselzaad dat in 2019 is neergedaald in de bank. De mosselen in bank 607 zijn in 2019 ongeveer 35 mm lang en laten daarmee eenzelfde groei zien als de mosselen op mosselbank 640. In deze bank is geen tweede cohort te onderscheiden in het lengte-frequentiediagram van 2019.

Mosselbroedval op de mosselbanken 502, 503, 603, 607 en 640 is, als gevolg van het bemonsteringsmoment rond mei, pas zichtbaar in het jaar erop. Hierdoor zijn deze mosselen al wat groter en kan de broedval door optreden van wintersterfte wat minder duidelijk gezien worden in de lengte-frequentiegrafieken dan op de banken 710, 727 en 736 die later in het jaar bemonsterd worden. Zoals hierboven aangegeven, is in de lengte-frequentiediagrammen van 607 en 640 geen tweede cohort te onderscheiden dat duidt op aanwas van mosselzaad uit 2019; mogelijk wordt dit veroorzaakt door het bemonsteringsmoment. Kijken we naar de lengteverdeling van de mosselen voor meerdere banken en jaren, dan blijkt dat zeer regelmatig, nagenoeg jaarlijks, wel enige mosselbroed valt in de banken. Hierdoor ontstaat de mosselpopulatie uit verschillende jaarklassen al na enkele jaren na het ontstaan van de bank. In de loop van de jaren zijn meestal twee, drie en soms vier jaarklassen te onderscheiden in de lengte-frequentiegrafieken. In sommige jaren zijn de individuele jaarklassen in elkaar vergroeid en zijn ze niet meer goed te onderscheiden. 


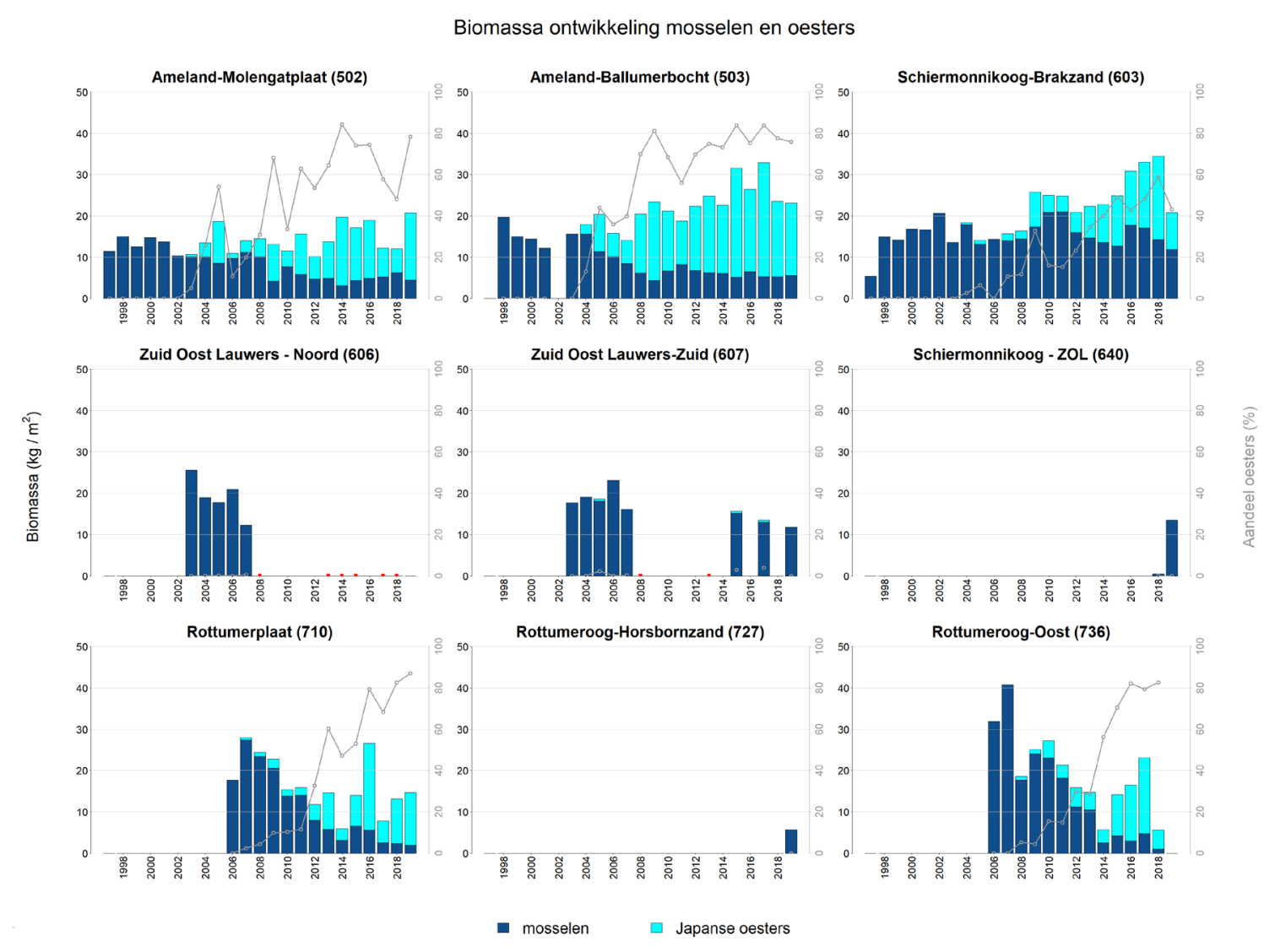

Figuur 3.12 Ontwikkeling van de jaargemiddelde biomassa mosselen en Japanse oesters (uitgedrukt in $\mathrm{kg}$ natgewicht $/ \mathrm{m}^{2}$ en weergegeven in staven ten opzichte van de linker $y$-as) en het aandeel oesters (uitgedrukt in procenten en weergegeven in lijndiagram ten opzichte van de rechter $y$-as) in de mossel-/oesterbiomassa zoals aangetroffen in de vierkantmonsters $\left(0,05 \mathrm{~m}^{2}\right)$ voor de banken 502 , 503, 603, 606, 607, 640, 703, 710, 727 en 736 in de periode $1997 \mathrm{t} / \mathrm{m} 2019$ (of tot wanneer ze bezocht zijn/aanwezig waren). Wanneer een bank wel bezocht werd maar niet aanwezig was, is dit met een rode stip aangegeven.

In de in 2018 nieuwe gevormde mosselbank 640 (Schiermonnikoog - Zuid Oost Lauwers) zijn de veranderingen in de mosselpopulatie in 2019 het grootst van de hier onderzochte banken. Het aantal mosselen in de monsters is sterk afgenomen, de biomassa en de individuele lengte van de mosselen zijn juist sterk toegenomen (zie Figuur 3.11, 3.12 en Bijlage 4). Dit is een normaal verschijnsel voor een nieuwgevormde mossel(zaad)bank met zeer veel kleine (en lichte) individuen die het jaar erop groeien.

Zoals ook in andere jaren werd gezien en als dusdanig in de eerdere rapportages werd beschreven, vindt er inmiddels een ontwikkeling van Japanse oesters plaats in nagenoeg alle in dit onderzoek bemonsterde mosselbanken van enige jaren ( $>5$ jaar) oud. Uitzondering zijn de in 2018 nieuwgevormde mosselbanken nabij Zuid Oost Lauwers (bank 640), Sparregat (bank 727) en Zuid Oost Lauwers - Zuid (607) waar (nog)geen oesters waargenomen zijn (zie Figuur 3.12).

Op de overige hier onderzochte banken $(502,503,603,710$ en 736) hebben zich op enig moment oesters gevestigd. In de eerste 3 tot 6 opvolgende jaren na de vestiging van oesters blijft de oesterbiomassa in de monsters nog beperkt. In de jaren daarna nam de oesterbiomassa wel sterk toe. Voor de meeste banken ging dit gepaard met een afname van de mosselbiomassa die voor de komst van de oesters tussen de 10 en $27 \mathrm{~kg} / \mathrm{m}^{2}$ lag en nu tussen de 1 en $6 \mathrm{~kg} / \mathrm{m}^{2}$ ligt (zie Figuur 3.12). Mosselbank 603 vormt hierop een uitzondering en heeft nog een wat hogere biomassa mosselen. In de periode 1998 tot en met 2019 schommelt de mosselbiomassa rond de $16 \mathrm{~kg} / \mathrm{m}^{2}\left( \pm 2.6 \mathrm{~kg} / \mathrm{m}^{2}\right.$ standaarddeviatie). In 2019 valt de afname van de oesterbiomassa in deze bank op (van $3.4 \mathrm{~kg} / \mathrm{m}^{2}$ in 
2018 naar $2.0 \mathrm{~kg} / \mathrm{m}^{2}$ in 2019), waardoor ook het aandeel oesters in de gecombineerde mosseloesterbiomassa afnam en in $2019<50 \%$ bedraagt.

Van de overige oudere mosselbanken met oesters die opgenomen zijn in dit programma is de mosselbiomassa van bank 710 in 2019 het kleinst, namelijk $1.9 \mathrm{~kg} / \mathrm{m}^{2}$ (zie Figuur 3.12). Bank 710 kent al sinds 2017 een relatief lage mosselbiomassa wanneer deze vergeleken wordt met de andere oudere mosselbanken waarin zich oesters gesetteld hebben (banken 502, 503 en 603). De mosselbiomassa van de banken 502 en 503 nemen een middenpositie in en ligt al jaren rond de $5 \mathrm{~kg} / \mathrm{m}^{2}$, zo ook in 2019. 


\subsection{Ontwikkeling dood materiaal en overige fauna}

\section{Samenstelling bodemdiermonsters}

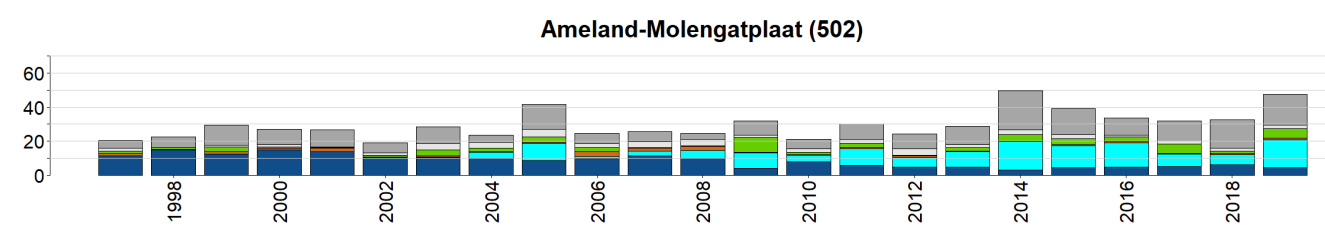

Ameland-Ballumerbocht (503)

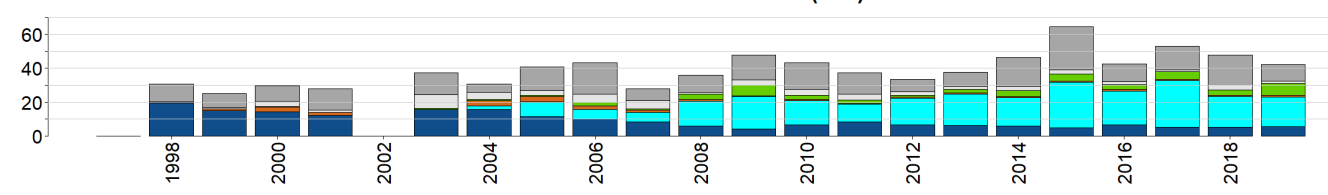

Schiermonnikoog-Brakzand (603)

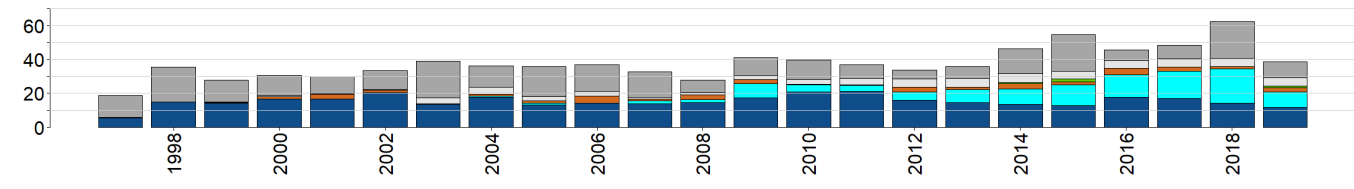

틀

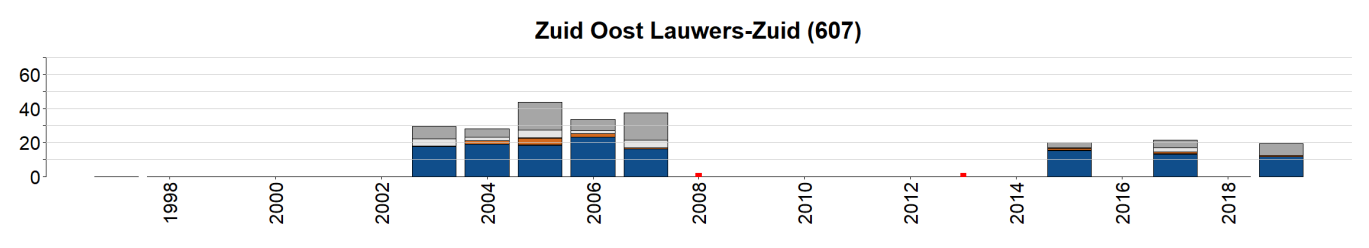

Schiermonnikoog - ZOL (640)
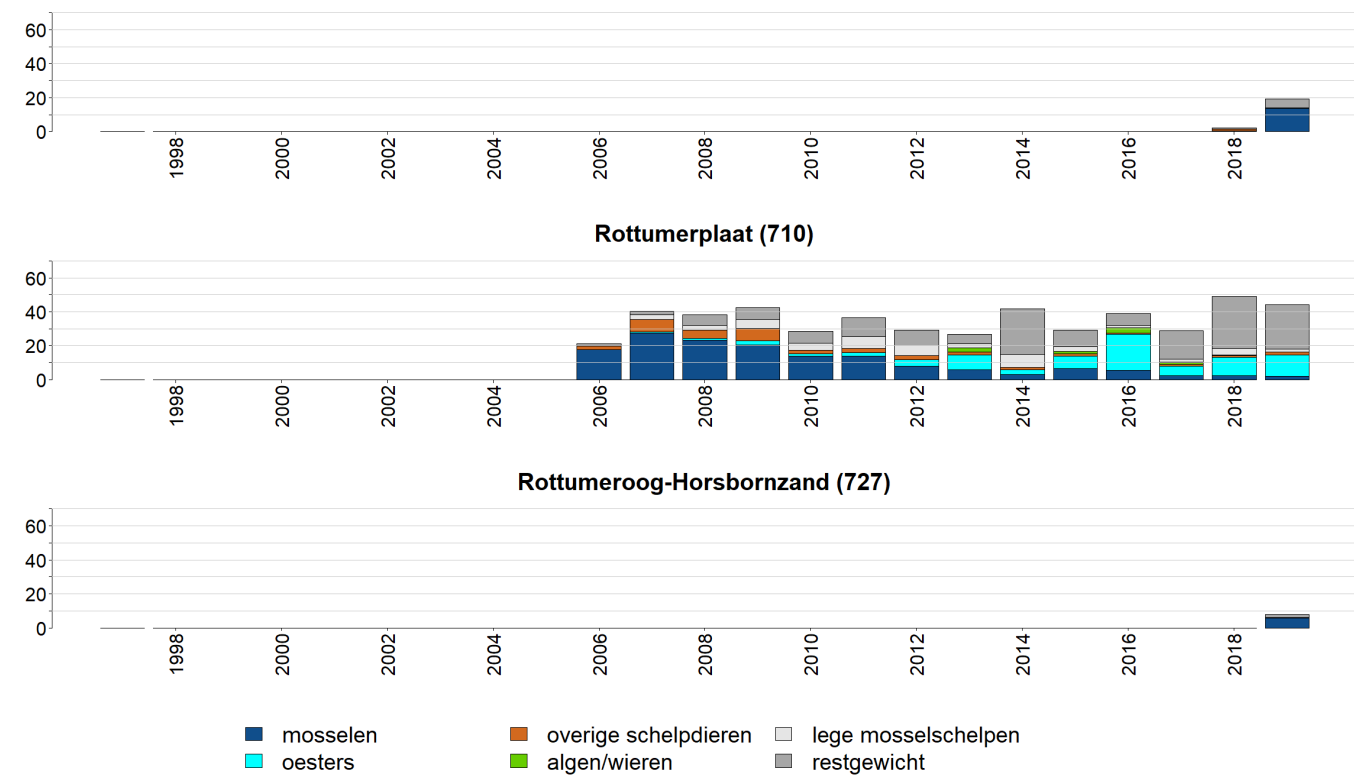

Figuur 3.13 Ontwikkeling van het gewicht aan mosselen, oesters, overige schelpdieren, algen/wieren, lege mosselschelpen en restgewicht zoals aangetroffen in de vierkantmonsters voor de banken 502, 503, 603, 640, 710 en 727 in de periode 1997 t/m 2019.

Het gewicht aan algen/wieren wordt gedomineerd door blaaswier (Fucus vesiculosus forma mytili) dat vooral in de monsters genomen op de banken 502 en 503 wordt aangetroffen (zie Figuur 3.13). Het dood materiaal in de monsters bestaat voornamelijk uit lege mossel- en oesterschelpen. De jaarlijkse fluctuaties in het gewicht en aandeel dood materiaal in de monsters zijn groot en zijn het meest uitgesproken op de banken onder de Rottums (zie Figuur 3.13). Gedurende de eerste 10 jaar na het ontstaan van de bank neemt het gewicht aan dood schelpenmateriaal nog toe, waarna deze stabiliseert (zie Figuur 3.14). 


\section{doodmateriaal in de monsters}

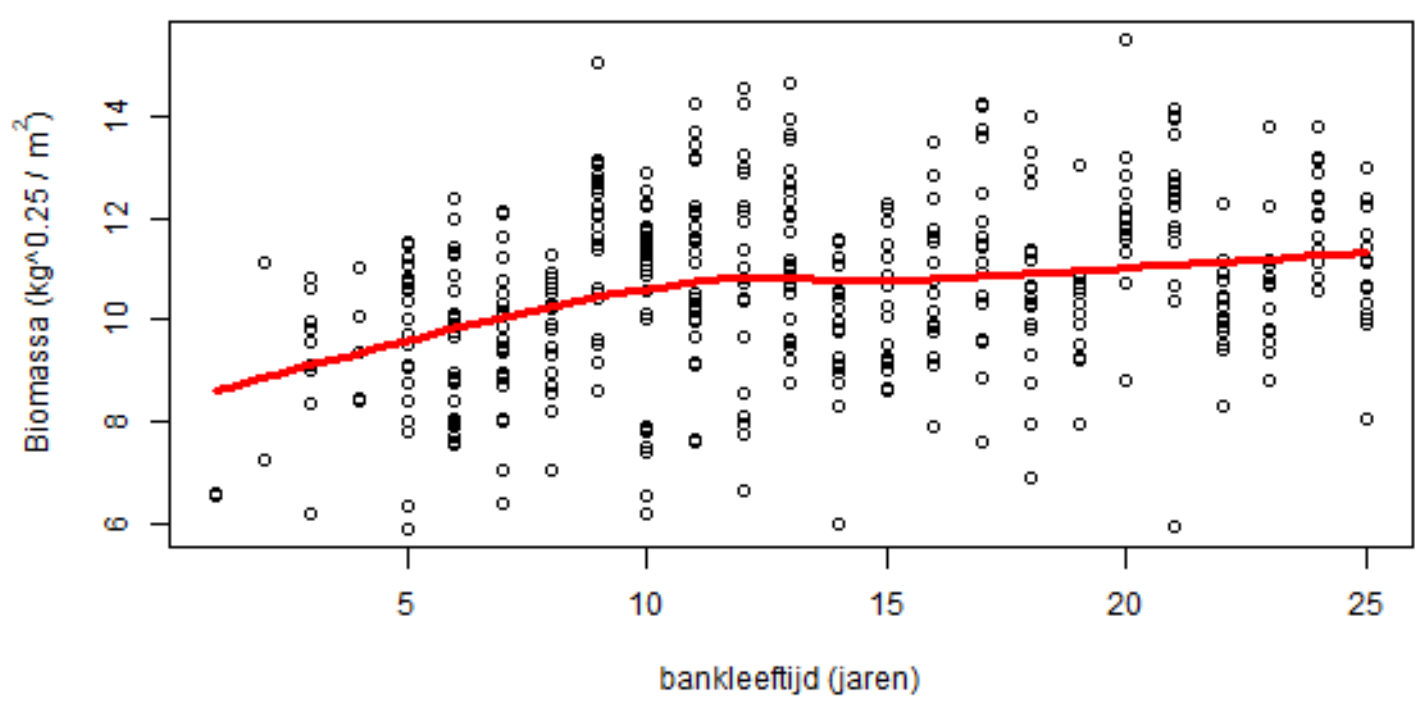

Figuur 3.14 Ontwikkeling van het gewicht aan dood materiaal in de monsters, uitgezet tegenover de mosselbankleeftijd (aantal jaar na het jaar van ontstaan van de bank). De rode lijn geeft het afgevlakte, voortschrijdend gemiddelde aan dood materiaal weer. 


\section{Samenstelling schelpdieren en krabben}
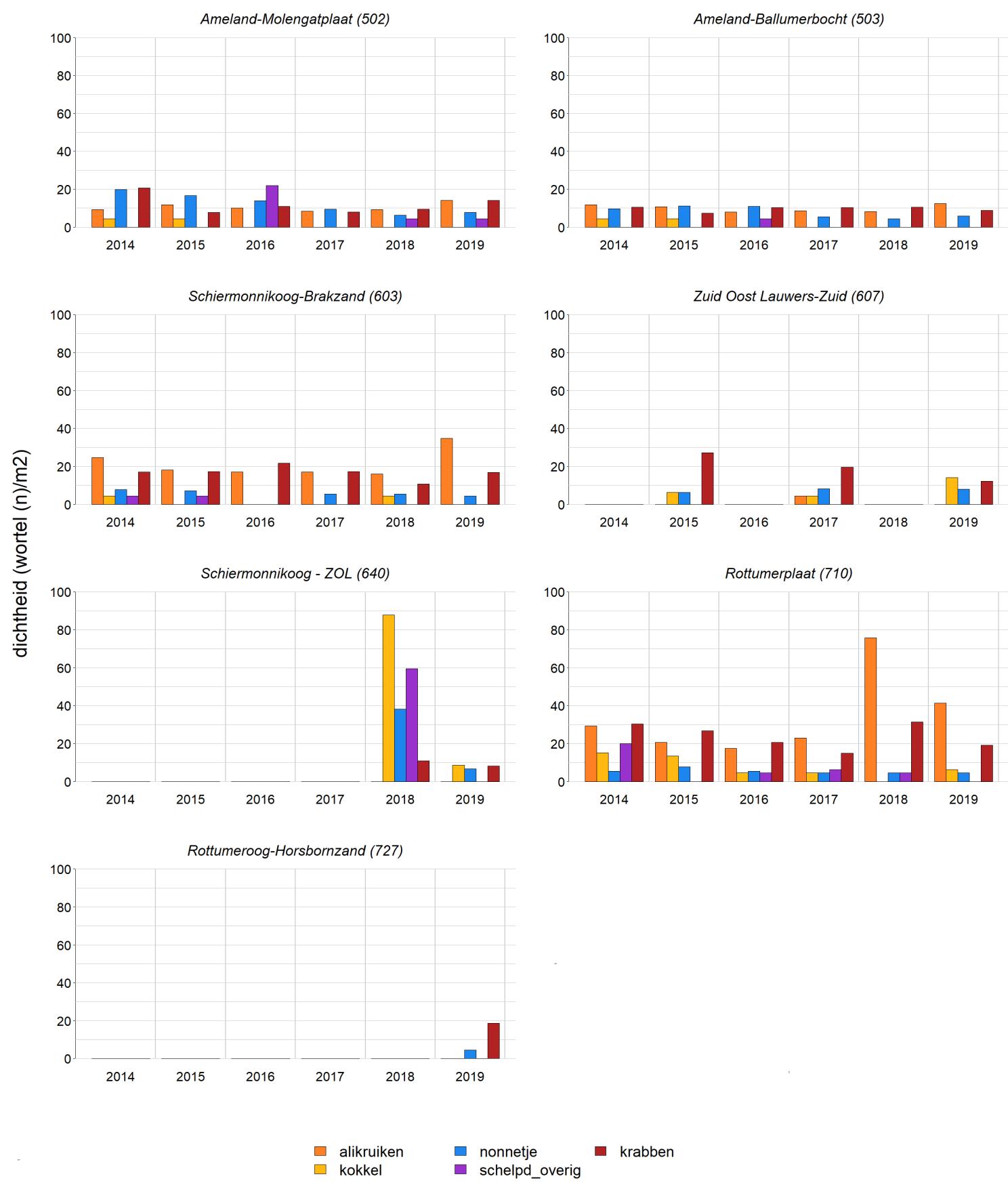

Figuur 3.15 Ontwikkeling van schelpdieren - anders dan mosselen en oesters - met de hoogste jaargemiddelde dichtheden (alikruiken, kokkel, nonnetje), de overige schelpdieren die maar enkele keren voorkomen als groep, en de krabben zoals aangetroffen in de vierkantmonsters voor de banken 502, 503, 603, 640, 710 en 727 in de periode 2014 t/m 2019.

In de monsters die genomen zijn in de oudere banken (mosselbanken 502, 503, 603 en 710) bestaat de krab- en schelpdiersamenstelling (exclusief mosselen en oesters) in de periode 2014 tot en met 2019 voor een groot deel uit alikruiken en krabben (zie Figuur 3.15). Hoewel minder numeriek dominant, worden er in deze banken ook nonnetjes aangetroffen en in mosselbank 710 ook kokkels. Het bemonsteringsjaar 2019 vormt geen uitzondering in de schelpdieren- en krabbensamenstelling. Deze banken waren in 2014 minimaal 13 jaar onafgebroken aanwezig. 
De jonge mosselbanken die in 2019 bemonsterd zijn, de banken 607, 640 en 727, laten een afwijkende schelpdieren- en krabbensamenstelling zien wanneer deze vergeleken worden met de oudere banken die hierboven beschreven zijn (zie Figuur 3.15). Alikruiken zijn niet of in veel mindere mate aangetroffen in deze jonge banken. De hoge aantallen (jonge) kokkels in de monsters genomen op mosselbank 640 laten zien dat de mosselbank zich gevormd heeft boven op een jonge kokkelbank. Aanwezigheid van jonge kokkels is ook in het veld waargenomen in zowel 2018 als 2019. Tevens werden veel nonnetjes en overige schelpdieren gevonden in de monsters. In 2019 is het aantal kokkels en nonnetjes in de monsters afgenomen, vergeleken met het jaar ervoor. Ook in mosselbank 607 werden in 2019 naast krabben en nonnetjes relatief veel kokkels aangetroffen in de monsters. In de monsters genomen op bank 727 in 2019 werden geen kokkels aangetroffen. Wel werden er krabben en nonnetjes aangetroffen (zie Figuur 3.15). Deze bank was twee jaar oud voordat deze in 2019 voor het eerst bemonsterd werd. 



\section{Discussie en conclusie}

Wageningen Marine Research bestudeert in detail de ontwikkelingen van een aantal droogvallende mosselbanken op de lange termijn. In het voorjaar van 2019 werden de mosselbanken 502 (Ameland Molengatplaat), 503 (Ameland - Ballumerbocht), 603 (Schiermonnikoog - Brakzand), 607 (Zuid Oost Lauwers - Zuid) en 640 (Schiermonnikoog - ZOL) bemonsterd. In het najaar werden de banken 710 (Rottumerplaat) en 736 (Rottumeroog-Oost) en 727 (Rottumeroog - Horsbornzand) bezocht. Mosselbank 727 werd in 2018 voor het eerst waargenomen en in 2019 voor het eerst bemonsterd. In 2019 is alleen de buitenste omtrek (contour) van mosselbank 736 opgemeten en zijn er geen monsters genomen voor het bepalen van de fauna.

De resultaten van de jaarlijkse kartering van deze banken en de populatiemetingen geven een beeld van de ontwikkeling van mosselbanken over een groot aantal jaren. De algemene conclusie, die ook al in voorgaande tussenrapportages wordt beschreven (o.a. Glorius et al., 2018), verandert daarmee niet. De mosselbanken gaan in het algemeen na het jaar van ontstaan langzaam achteruit in oppervlakte, bedekkingspercentage en populatiedichtheid. Op de mosselbanken neemt dan het percentage lege schelpen, macroalgen en zeepokken toe in verhouding tot de levende mosselen. Van de hier onderzochte banken worden, naast mosselen, oesters en macroalgen, alikruiken en krabben veelvuldig aangetroffen op de oudere banken. Kokkels worden vooral in de jongere banken aangetroffen. De afname in oppervlakte en bedekking van een bestaande mosselbank wordt af en toe tenietgedaan door een goede broedval, waarna het proces opnieuw begint. Over de jaren ontstaat dus geleidelijk een mosselbank met meerdere jaarklassen en met een gevarieerde gemeenschap. Vestiging van Japanse oesters in bestaande mosselbanken blijkt een algemeen verschijnsel in de Waddenzee, wat resulteert in een hoger bedekkingspercentage aan schelpdieren en een afnemende biomassa mosselen.

De gemengde mossel- en oesterbanken kunnen een stabiel en langdurig (decennia) verschijnsel zijn op een bepaalde locatie, al kunnen individuele mosselen, bankdelen en complete banken ook verdwijnen en veel korter aanwezig zijn. Ondanks de overeenkomsten in algemene ontwikkeling zoals hierboven beschreven, zijn er jaarlijks grote verschillen te zien in de ontwikkeling van individuele mosselbanken die in deze studie gevolgd zijn. Sommige banken nemen in oppervlak en bedekking af, andere nemen juist toe of veranderen nagenoeg niet. Op sommige mosselbanken vindt er bijvoorbeeld een mossel- of oesterbroedval plaats, op andere niet. Folmer (e.a.) heeft de dynamiek in bankgrootte van litorale mosselbanken aanwezig in de Nederlandse en Duitse Waddenzee bestudeerd voor de periode 1999-2010 en kwamen tot de conclusie dat groei van banken uit verschillende stroomgebieden niet synchroon verloopt (Folmer et al., 2014). De auteurs stellen dat lokale verschillen in de verspreiding van mossellarven en de barrière die de uitstroom van rivieren hierin vormt, mogelijk belangrijk zijn. Beukema (e.a.) vond wel gelijktijdige groei van mosselbanken over grote gebieden (>100 km) na koude winters (Beukema et al., 2015). De auteurs stellen dat de bestudeerde periode in de studie van Folmer (e.a.) te kort was en geen strenge winters bevatte om deze relatie op te merken.

Onderzoek wijst uit dat veel verschillende factoren bepalend zijn voor de overleving en ontwikkeling van litorale mosselbanken en dat deze ook samenhangen met eigenschappen van de mosselbank zelf en met de levensfase van de mosselbank (Dankers \& Fey, 2015). Zo wordt mosselbroedval op een bank bepaald door aanvoer van mossellarven met waterstromen die bovendien voldoende groot (en zwaar) moeten zijn om te kunnen bezinken op momenten met weinig stroming (Dankers \& Fey, 2015). Het moment waarop de larven groot genoeg gegroeid zijn om zich op de bodem te vestigen, wordt mede bepaald door het daaraan voorafgaande moment waarop de mosselen hun zaad- en eiercellen uitscheiden (afhankelijk van de watertemperatuur) en door de groeisnelheid van de larven, wat weer afhankelijk is van onder andere voedselcondities (Gosling, 1992). Succesvolle vestiging van mossellarven wordt mede bepaald door het substraat waarbij in ieder geval mosselen zelf (Kangeri et al., 2014), kokkels, oesters, dode schelpen en de kokers van kokerwormen (Callaway, 2003; 
Dankers \& Fey, 2015; Pulfrich, 1996) geschikt blijken te zijn. Direct na vestiging is predatie door krabben en garnalen belangrijk (Waser, 2018; Van der Veer et al., 1998; Dankers \& Fey, 2015). In alle levensfasen van mosselbanken kan erosie van bankdelen door golven, stromingen en ijsvorming belangrijk zijn (Donker, 2015) en kunnen er grote verliezen optreden door predatiedruk uitgeoefend door vogels (Waser, 2018). Ook bankeigenschappen zelf zijn van belang. De ruimtelijke structuur van de mosselen (Liua et al., 2013), ligging ten opzichte van overheersende stroomrichting, het reliëf en de aan- dan wel afwezigheid van mosselbulten (Donker, 2015) bepalen onder andere de gevoeligheid van mosselbanken voor erosie door golven en stromingen en de beschikbaarheid van voedsel. De voedselbeschikbaarheid wordt verder bepaald door de ligging van de bank ten opzichte van geulen die voor aanvoer van algen (voedsel) zorgen en de hoogteligging, die bepaalt hoe lang de bank onder water staat en dus hoe lang mosselen de tijd hebben het water te filteren (Dankers \& Fey, 2015). Japanse oesters kunnen mosselen bescherming bieden en verliezen door predatie verminderen (Waser et al., 2015).

Van der Meer et al. (2018) laten zien dat de bankoverleving in de eerste vijf jaar na het ontstaan van een mosselbank gering is. Veel nieuwgevormde banken verdwijnen binnen de eerste vijf jaar. De overlevingskansen na de eerste vijf jaar nemen sterk toe. De overlevingskansen zijn daarnaast groter dan gemiddeld voor mosselbanken waarin ook Japanse oesters (zgn. 'gemixte' banken) aanwezig zijn. Hieruit volgt dat met name de ontwikkeling van de mosselbanken in de eerste vijf jaar na het ontstaan van de bank belangrijk zijn in langjarige overleving. Naast het volgen van de oude banken is het in het kader van dit onderzoek verstandig om informatie te verzamelen over nieuwgevormde banken en deze te blijven volgen in de opvolgende jaren. Het wordt daarom aanbevolen de in 2018 nieuwgevormde mosselbanken Schiermonnikoog (640) en Rottumeroog - Horsbornzand (727) te blijven monitoren gedurende de komende jaren. Ook zouden nieuwgevormde banken aan het programma toegevoegd kunnen worden. Het is de verwachting dat verschillen in en ontwikkeling van de bankgrootte, mossel-/oesterbedekking en (hoogte)ligging van de patches belangrijk zijn voor het al dan niet langjarig overleven van een bank. Gedetailleerdere gegevens over deze parameters kunnen verkregen worden door vlakdekkende beeldopnames te maken met een UAV ('Unmanned Aerial Vehicle' ofwel drone) en deze te analyseren. Naast een samengesteld beeld (van zichtbaar licht) dat de gehele mosselbank bestrijkt, kan ook een hoogtemodel geconstrueerd worden waarmee hoogteverschillen in een bank onderzocht kunnen worden. Inmiddels zijn de eerste ervaringen hiermee op kleine schaal opgedaan. Hieruit blijkt dat het mogelijk is de meeste mosselbanken in de periode van een getij op te nemen. Ook bleek het mogelijk mosselpatches te identificeren uit het beeldmateriaal (Glorius et al., in voorbereiding) en een hoogtemodel te construeren. Daarmee was het mogelijk veranderingen in mosselbedekking en hoogteligging te volgen over de tijd. Het wordt aanbevolen om deze techniek verder te ontwikkelen in het kader van dit onderzoek. Getoetst moet worden hoe goed de techniek werkt voor de banken die in dit programma opgenomen zijn, met onder andere een andere mosseloestersamenstelling en hoe deze zich verhoudt met de gegevens zoals ze tot nu toe verkregen worden (lopen van contour en bedekkingsraaien met hand-gps). Op termijn is het dan in potentie mogelijk het lopen van bedekkingsraaien achterwege te laten en over te stappen op het gebruik van een UAV waarmee het de verwachting is dat met eenzelfde inspanning steeds gedetailleerdere informatie verkregen kan worden die belangrijk is voor de (vroege) bankoverleving. Ook kan in potentie onderzocht worden wat het effect van de aanwezigheid van een mosselbank is op de hoogteligging en sedimentsamenstelling van zijn directe omgeving. Daarnaast is het interessant om de ontwikkeling van de banken te koppelen aan morfologische ontwikkelingen in de directe omgeving van de bank. Hiertoe zouden mosselbankcontouren geprojecteerd kunnen worden op historische bathymetrische kaarten, waarmee mogelijk onderzocht kan worden wat de invloed is van mosselbanken op sedimentatie- en erosieprocessen en op de verschuivingen in het geulenpatroon.

De hier gepresenteerde meerjarige gegevens met betrekking tot de ontwikkeling van mosselbanken kunnen bijdragen aan de verdere ontwikkeling van kennis over de invloed van bankeigenschappen en omgevingsfactoren die van belang zijn voor het overleven van mosselbanken, evenals de invloed van oesters op de mosselbank- en mosselpopulatiedynamiek. 


\section{Literatuur}

Asmus, R.M. \& H. Asmus (1991) Mussel beds: limiting or promoting phytoplankton? Journal of Experimental Marine Biology and Ecology 148:215-32.

Beukema, J.J., R. Dekker, M.R. van Stralen, J. de Vlas (2015) Large-scale synchronization of annual recruitment success and stock size in Wadden Sea populations of the mussel Mytilus edulis $\mathrm{L}$. Helgol Mar Res (69), pp 327 - 333.

Brinkman, A.G., T. Bult, N. Dankers, A. Meijboom, D. den Os, M.R. van Stralen, J. de Vlas (2003) Mosselbanken kenmerken, oppervlaktebepaling en beoordeling van stabiliteit. Alterra rapport 707. Alterra Wageningen UR, Wageningen.

Buschbaum, C.S., Dittmann, J.S Hong, I.S Hwang, M. Strasser, M. Thiel, N. Valdivia, S.P. Yoon, K. Reise (2009) Mytilid mussels: global habitat engineers in coastal sediments. Helgoland Marine Resources 63:47-58.

Callaway, R. (2003) Long-term effects of imitation polychaete tubes on benthic fauna: they anchor Mytilus edulis (L.) banks. Journal Experimental Marine Biology Ecology (283), pp 115-132.

Dame, R.F., N. Dankers, T. Prins, H. Jongsma \& A. Smaal (1991) The influence of mussel beds on nutrients in the western Wadden Sea and Eastern Scheldt estuaries. Estuaries 130-138-14.

Dame, R.F. (2011) Ecology of marine bivalves: an ecosystem approach, $2^{\text {nd }}$ edition. Boca Raton, FL, CRC Marine Sciences. 283 pp.

Dankers, N. \& K. Koelemaij (1989) Variations in the mussel population of the Dutch Waddensea in relation to monitoring. Helgwiss. Meeresunters. 43: 529-535.

Dankers, N., A. Meijboom, J.S.M. Cremer, E.M. Dijkman, Y. Hermes, L. te Marvelde (2003) Historische ontwikkeling van droogvallende mosselbanken in de Nederlandse Waddenzee. Alterra-rapport 876. Alterra Wageningen UR, Wageningen.

Dankers, N, A. Meijboom, M. de Jong, E. Dijkman, J. Cremer \& S. van der Sluis (2004) Het ontstaan en verdwijnen van droogvallende mosselbanken in de Nederlandse Waddenzee. Alterra-rapport 921. Alterra Wageningen UR, Wageningen.

Dankers, N., J. Cremer, E. Dijkman, S. Brasseur, K. Dijkema, F. Fey-Hofstede, M. de Jong, C. Smit (2006) Ecologische Atlas Waddenzee. IMARES Wageningen UR, Texel.

Dankers, N. \& F. Fey-Hofstede (2015) Een zee van Mosselen. Handboek ecologie, bescherming, beleid en beheer van mosselbanken in de Waddenzee. Lisse, pp. 108.

Donker, J.J.A. (2015) Hydrodynamic processes and the stability of intertidal mussel beds in the Dutch Wadden Sea. Thesis University Utrecht, pp 134.

Dijkema, K.S., G. Van Tienen \& J.J. Van Beek (1989) Habitats of the Netherlands, German and Danish Wadden Sea 1:100 000. Research Institute for Nature Management, Texel/Veth Foundation, Leiden: 24 maps.

Ende ,D. van den, K. Troost, M. van Asch, J. Perdon \& C. van Zweeden (2019) Mosselbanken en oesterbanken op droogvallende platen van de Nederlandse zoute getijdenwateren 2019; bestand en arealen. CVO rapport 19.022 .

Ens, B.J. \& D. Alting (1996) The effect of an experimentally created mussel bed on bird densities and food intake of the Oystercatcher Haematopus ostralegus. Ardea, 84A, 493-507.

Folmer, E.O., J. Drent, K. Troost, H. Buttger, N. Dankers, J. Jansen, M. van Stralen, G. Millat, M. Herlyn, C.J.M. Philippart, C.J.M. (2014) Large-Scale Spatial Dynamics of Intertidal Mussel (Mytillus edulis L.) bed coverage in the Gemena and Dutch Wadden Sea. Ecosystems (17), pp 550-566.

Glorius, S.T., A. Meijboom, J.T. van der Wal, J.S.M. Cremer (2018) Ontwikkeling van enkele mosselbanken in de Nederlandse Waddenzee, situatie 2016. WOT-technical report 138 / WMRrapport C018/19.

Gosling, E.G. (1992) Reproduction, settlement and recruitment. In: The Mussel Mytilus: ecology, physiology, genetics and culture. Developments in aquaculture and fisheries science. Amsterdam: Elsevier. Pp 131-168.

Gutiérrez, J.L., C.G. Jones, D.L. Strayer, O.O. Iribarne (2003) Mollusks as ecosystem engineers: the role of shell production in aquatic habitats. Oikos 101: 79-90. 
Günther, C.P. (1996) Development of small Mytilus beds and its effects on resident intertidal macrofauna. Mar. Ecol. 17(1-3):117-130.

Kangeri, A.K., J.M. Jansen, D.J. Joppe, N.M.J.A. Dankers (2014) In situ investigation of the effects of current velocity on sedimentary mussel bed stability. Journal of Experimental Marine Biology and Ecology (485), pp 65-72.

Kochmann, J., C. Buschbaum, N. Volkenborn, \& K. Reise (2008) Shift from native mussels to alien oysters: Differential effects of ecosystem engineers. Journal of Experimental Marine Biology and Ecology, 364(1):1-10.

Liua, Q.X., A. Doelman, V. Rottschafer, M. de Jager, P.M.J. Herman, N. Rietkerk, J. van de Koppel (2013) Phase separation explains a new class of selforganized spatial patterns in ecological systems. PNAS.

Markert, A. A. Wehrmann, I. Kröncke (2010) Recently established Crassostrea-reefs versus native Mytilus-beds: differences in ecosystem engineering affects the macrofaunal communities (Wadden Sea of Lower Saxony, southern German Bight). Biological Invasions, 12:15-32.

Meer van der, J., N. Dankers, B. Ens, M. van Stralen, K. Troost \& A. Waser (2018) 'The Birth, Growth and Death of Intertidal Soft-Sediment Bivalve Beds: No Need for Large-Scale Restoration Programs in the Dutch Wadden Sea", Ecosystems (22), 1024-1034.

Ministerie van LNV (2004) Ruimte voor zilte oogst. Naar een omslag in de Nederlandse schelpdiercultuur. Beleidsbesluit Schelpdiervisserij 2005-2020.in N. e. V. Ministerie van Landbouw, editor., Den Haag.

Ministerie van LNV (2008) Profieldocument H1140 december NB-wet Natura 2000. http://www.synbiosys.alterra.nl/natura2000/documenten/profielen/habitattypen/profiel_habitatty pe_1140.pdf

Ministerie van Infrastructuur en Milieu (2016) Natura 2000-beheerplan Waddenzee, periode 2016 2022. pp 331.

Nehls, G., I. Hertzler, G. Scheiffarth (1997) Stable mussel Mytilus edulis beds in the Wadden Sea: they're just for the birds. Helgolander Meeresuntersuchungen 51:361-72.

Petersen, J.K., M. Maar, F. Mohlenberg and J.E.N. Larsen (2012) Benthic grazing impact: Coupling and uncoupling in relation to physical forcing. Marine Ecology Progress Series 463: 127-139.

Prins, T.C., A.C. Smaal and R.F. Dame (1998) A review of the feedbacks between bivalve grazing and ecosystem processes. Aquatic Ecology 31: 349-359.

Prins, T.C. \& V. Escaravage (2005) Can bivalve suspension feeders affect pelagic food web structure? In: The Comparative Roles of Suspension Feeders in Ecosystems. R.F. Dame and S. Olenin. Dordrecht Springer: 31-51.

Pulfrich, A. (1996) Attachment and settlement of post-larval mussels (Mytilus edulis L.) in the Schleswig-Holstein Wadden Sea. J. Sea Res. 36, pp 239-250.

Tsuchiya, M., M. Nishihira (1985) Islands of Mytilus as a habitat for small intertidal animals: effect of island size on community structure. Mar Ecol Prog Ser 25:71-81.

Tsuchiya, M., M. Nishihira (1986) Islands of Mytilus edulis as a habitat for small intertidal animals: effect of Mytilus age structure on the species composition of the associated fauna and community organization. Mar Ecol Prog Ser 31:171-187.

Tydeman, P. (1996) Ecologisch profiel van de wilde litorale mosselbank (Mytilus edulis L.). Rapport RIKZ 96.026. RIKZ, Den Haag.

Veer, H.W. van der, R.J. Feller, A. Weber, J. Witte, (1998) Importance of predation by crustaceans upon bivlave spat in het intertidal zone of the Dutch Wadden Sea as revealed by immunological assays of gut contents. Journal Experimental Marine Biology and Ecology (231), pp 139 - 157.

Waser, A.M. (2018) Predation on intertidal mussels:Influence of biotic factors on the survival of epibenthic bivalve beds. PhD Thesis, Vrije Universiteit Amsterdam, Amsterdam, The Netherlands.

Waser, A.M., W. Splinter \& J. van der Meer (2015) Indirect effects of invasive species affecting the populationstructure of an ecosystem engineer. Ecosphere 6(7):109. http://dx.doi.org/10.1890/ES14-00437.1

Zwarts, L. (1991) Mosselbanken: wadvogels op een kluitje. Vogels 66: 8-12. 


\section{Verantwoording}

WOt-technical report: 192

BAPS-projectnummer: WOT-04-009-035.01

WMR-Rapport C108/20

WMR-Projectnummer: 43.181.002.46

Dit rapport is met grote zorgvuldigheid tot stand gekomen. De wetenschappelijke kwaliteit is intern getoetst door een collega-onderzoeker en het verantwoordelijk lid van het managementteam van Wageningen Marine Research

Akkoord: $\quad$ Dr. Ruud Jongbloed
Senior onderzoeker

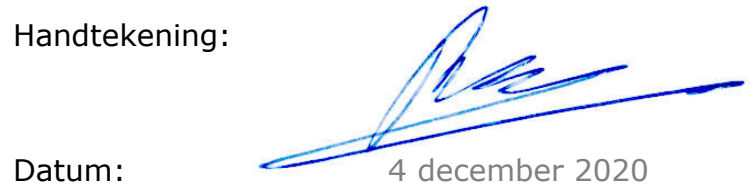

Akkoord: Drs. Jakob Asjes MT lid integratie

Handtekening:

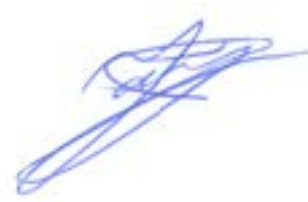

Datum:

4 december 2020

Akkoord Extern contactpersoon

functie: Beleidsmedewerker Trilaterale Samenwerking in de Waddenzee

naam: Karst Jaarsma

datum: $\quad 3$ december 2020

Akkoord Intern contactpersoon

naam: $\quad$ Anne Schmidt

datum: $\quad 3$ december 2020 



\section{Bijlage 1 Contour per jaar en bank}

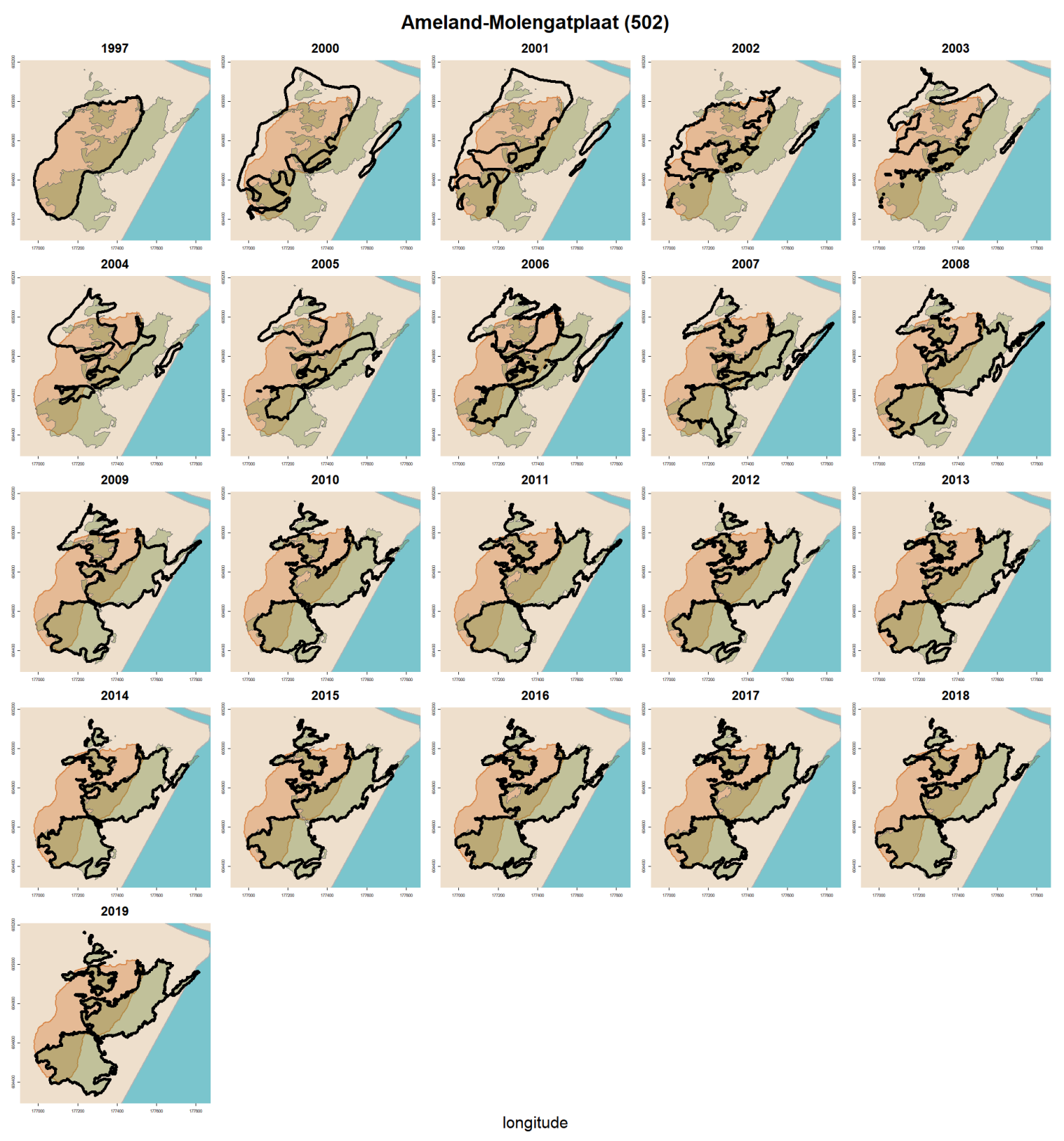

Figuur B1.1 De contouren voor mosselbank 502 (Ameland - Molengatplaat) voor de verschillende jaren. De contour zoals die bepaald is in de eerste meting van dit programma is lichtbruin ingekleurd, de contour zoals die bepaald is in 2019 is lichtgroen ingekleurd en zoals die bepaald is in elk van de afzonderlijke jaren is zwart omlijnd. 


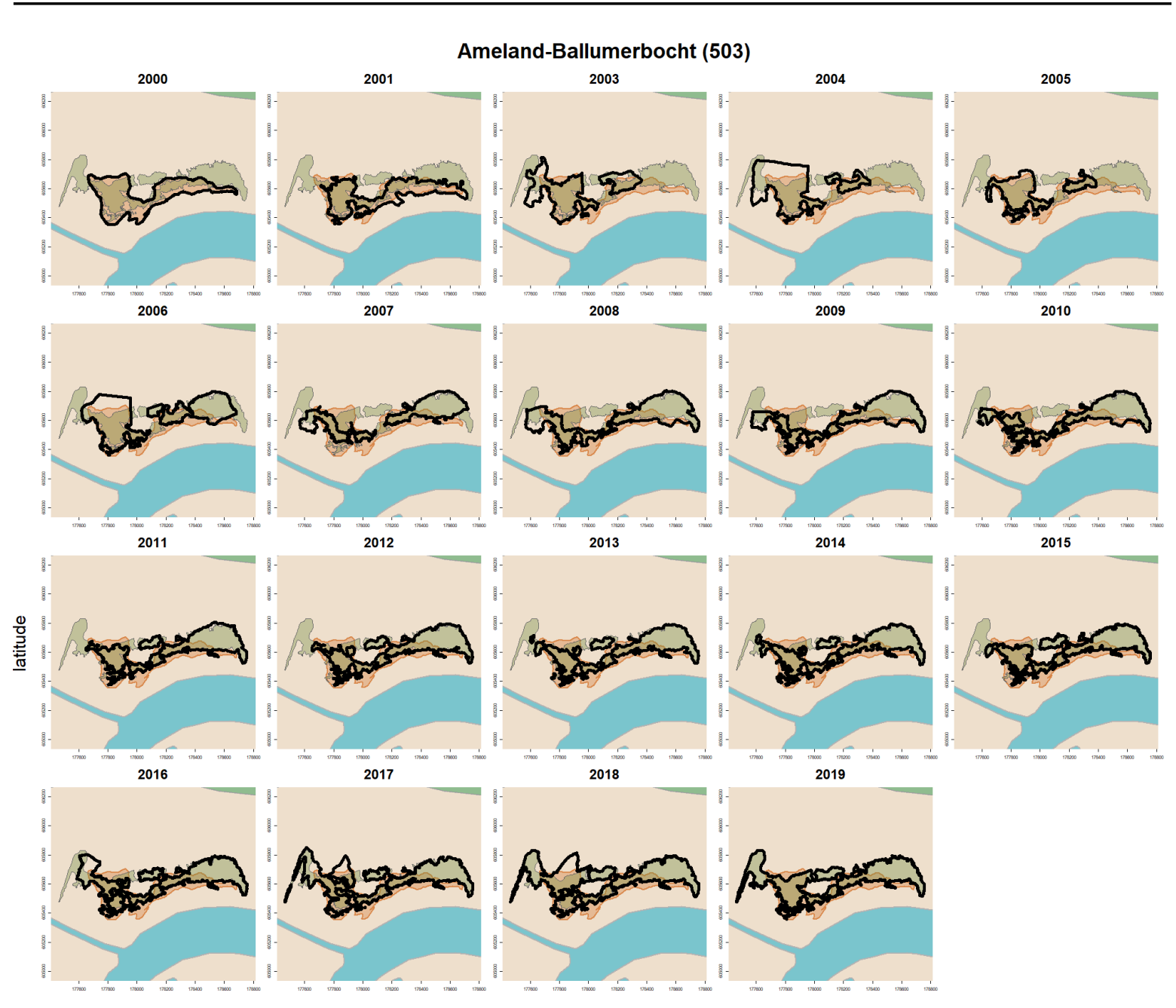

Figuur B1.2 De contouren voor mosselbank 503 (Ameland - Ballumerbocht) voor de verschillende jaren. De contour zoals die bepaald werd in de eerste meting van dit programma is lichtbruin ingekleurd, de contour zoals die bepaald werd in 2019 is lichtgroen ingekleurd en zoals die bepaald werd in elk van de afzonderlijke jaren is zwart omlijnd. 


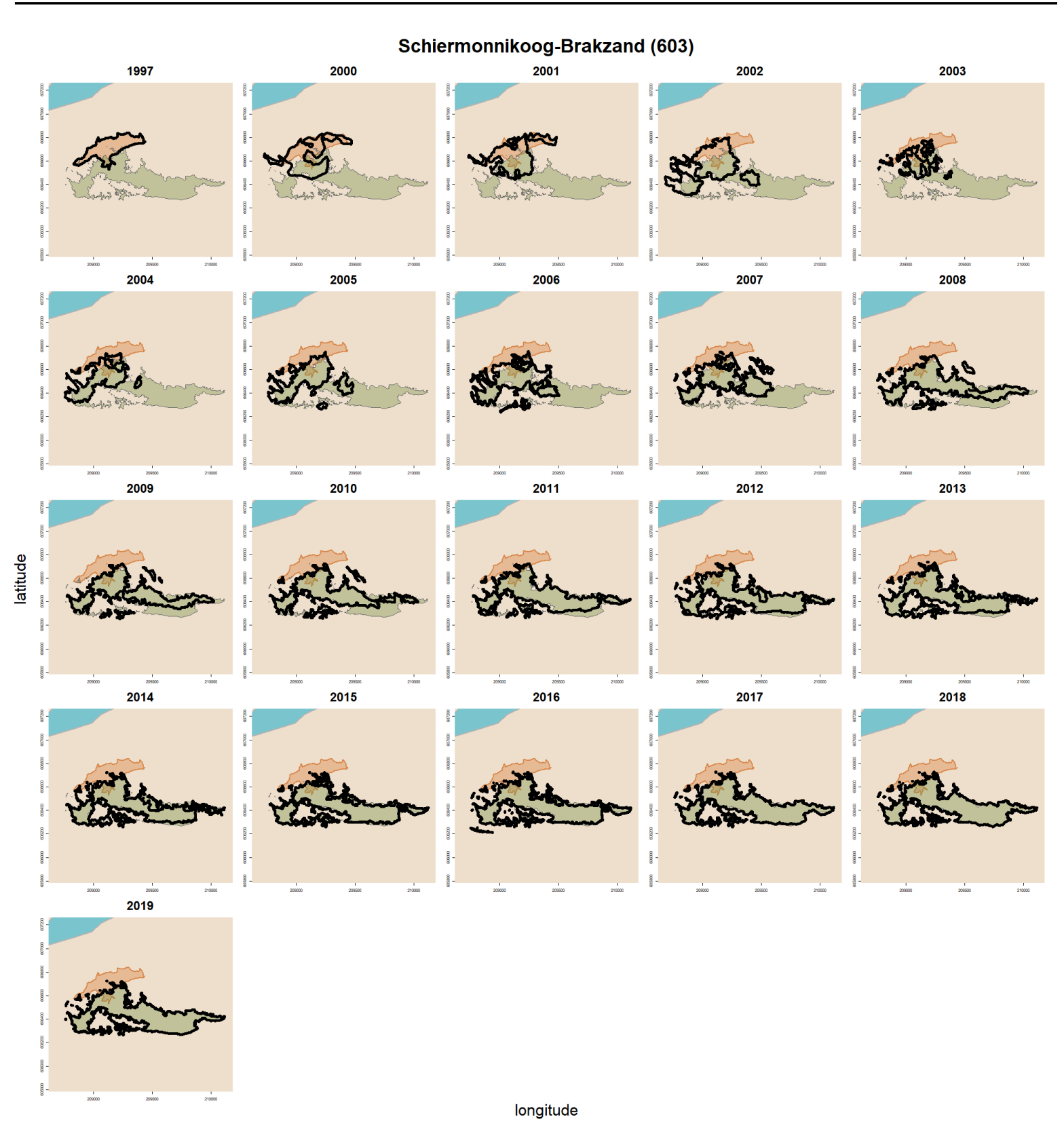

Figuur B1.3 De contouren voor mosselbank 603 (Schiermonnikoog - Brakzand) voor de verschillende jaren. De contour zoals die bepaald werd in de eerste meting van dit programma is lichtbruin ingekleurd, de contour zoals die bepaald werd in 2019 is lichtgroen ingekleurd en zoals die bepaald werd in elk van de afzonderlijke jaren is zwart omlijnd. 


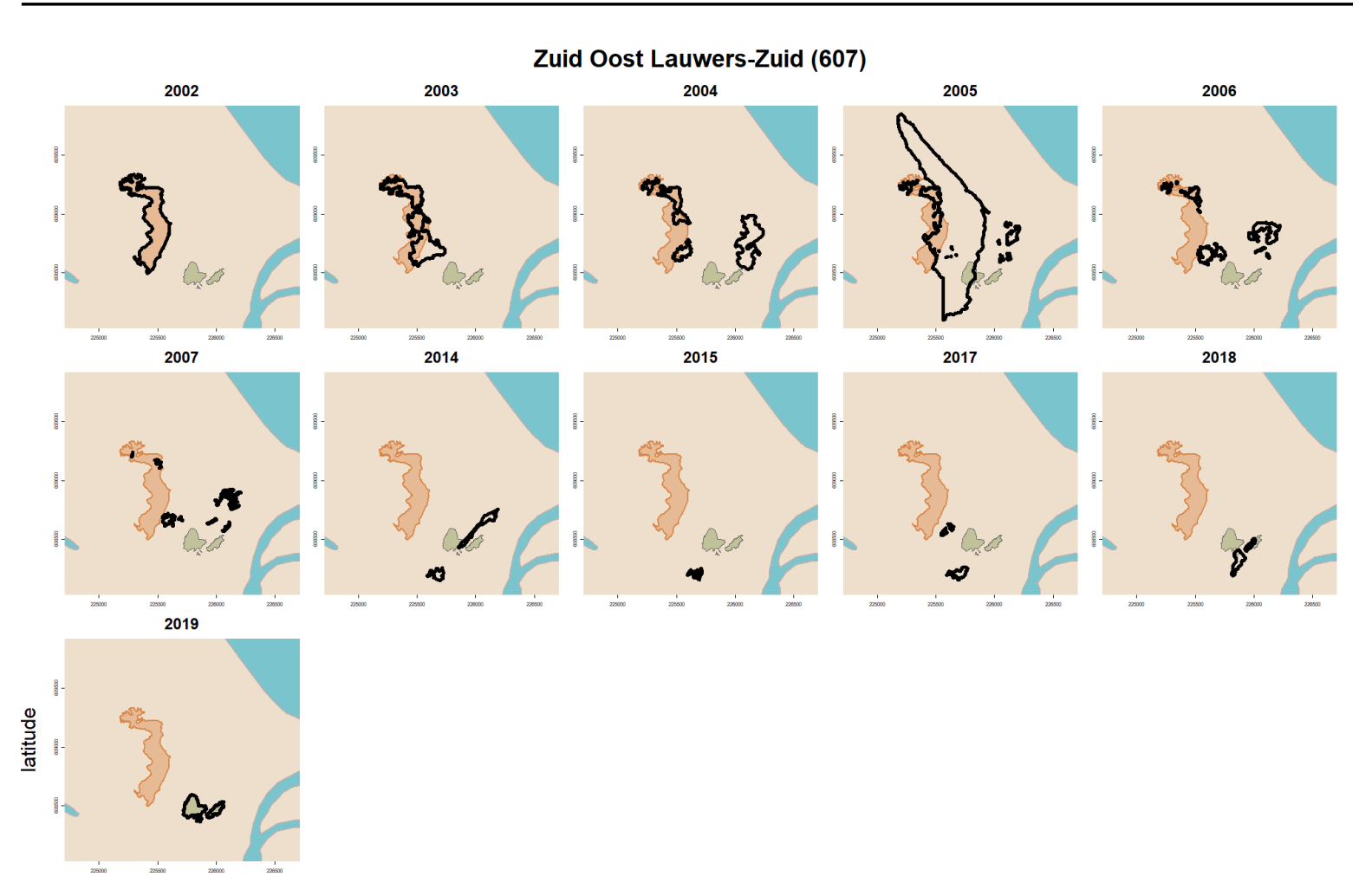

Figuur B1.4 De contouren voor mosselbank 607 (Zuid Oost Lauwers - Zuid) voor de verschillende jaren. De contour zoals die bepaald werd in de eerste meting van dit programma is lichtbruin ingekleurd, de contour zoals die bepaald werd in 2019 is lichtgroen ingekleurd en zoals die bepaald werd in elk van de afzonderlijke jaren is zwart omlijnd.

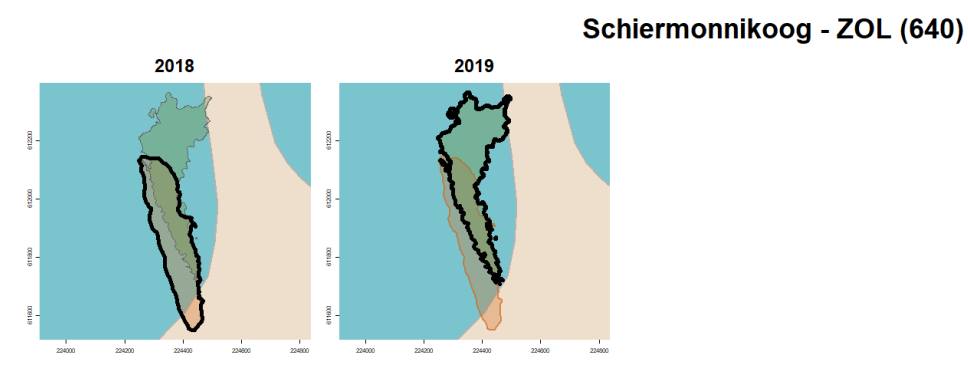

Figuur B1.5 De contouren voor mosselbank 640 (Schiermonnikoog -Zuid Oost Lauwers) voor de verschillende jaren. De contour zoals die bepaald werd in de eerste meting van dit programma is lichtbruin ingekleurd, de contour zoals die bepaald werd in 2019 is lichtgroen ingekleurd en zoals die bepaald werd in elk van de afzonderlijke jaren is zwart omlijnd. 


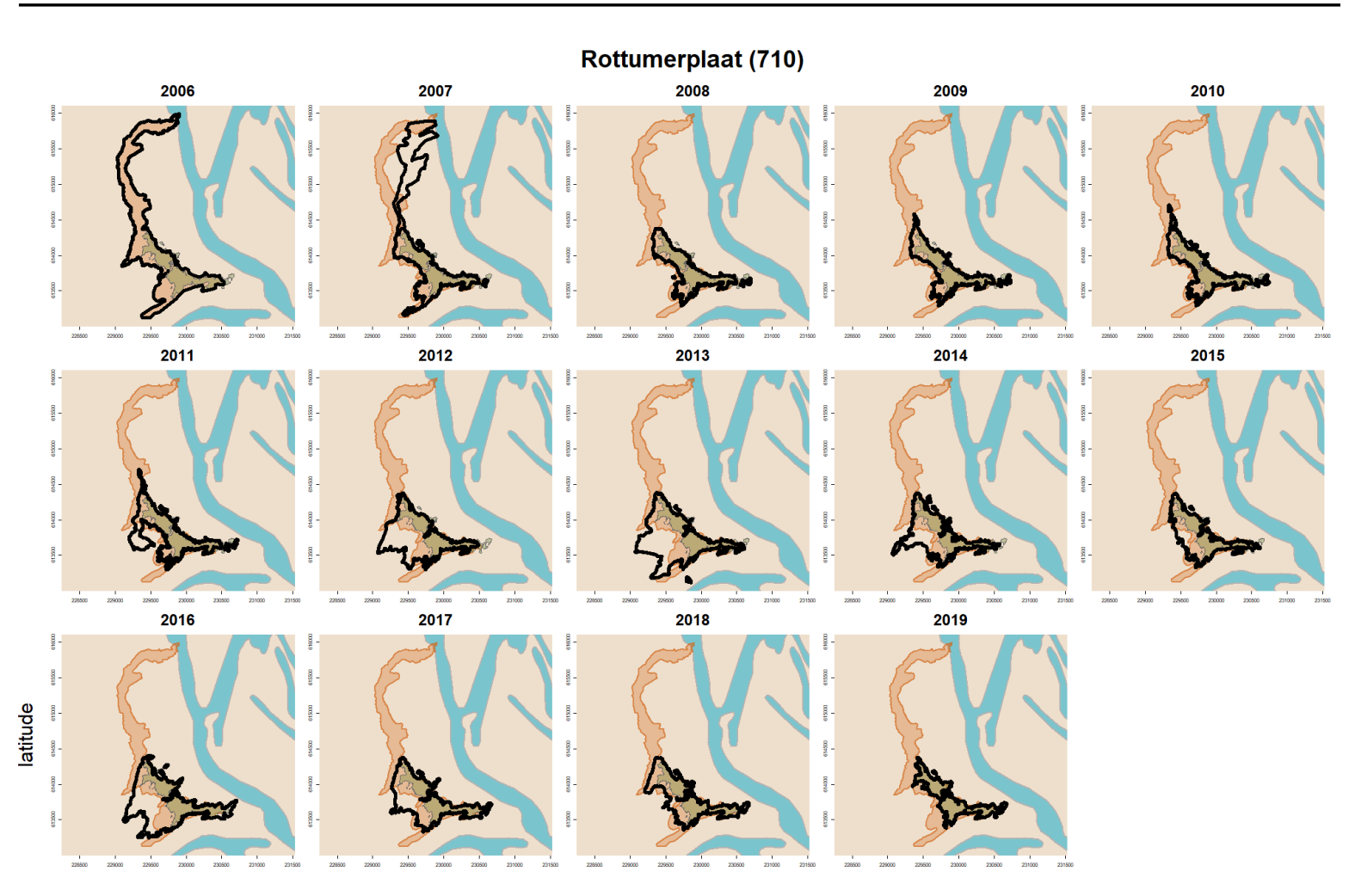

Figuur B1.6 De contouren voor mosselbank 710 (Rottumerplaat) voor de verschillende jaren. De contour zoals die bepaald werd in de eerste meting van dit programma is lichtbruin ingekleurd, de contour zoals die bepaald werd in 2019 is lichtgroen ingekleurd en zoals die bepaald werd in elk van de afzonderlijke jaren is zwart omlijnd. 



\section{Bijlage 2 Kaart-Mosselbedekking}

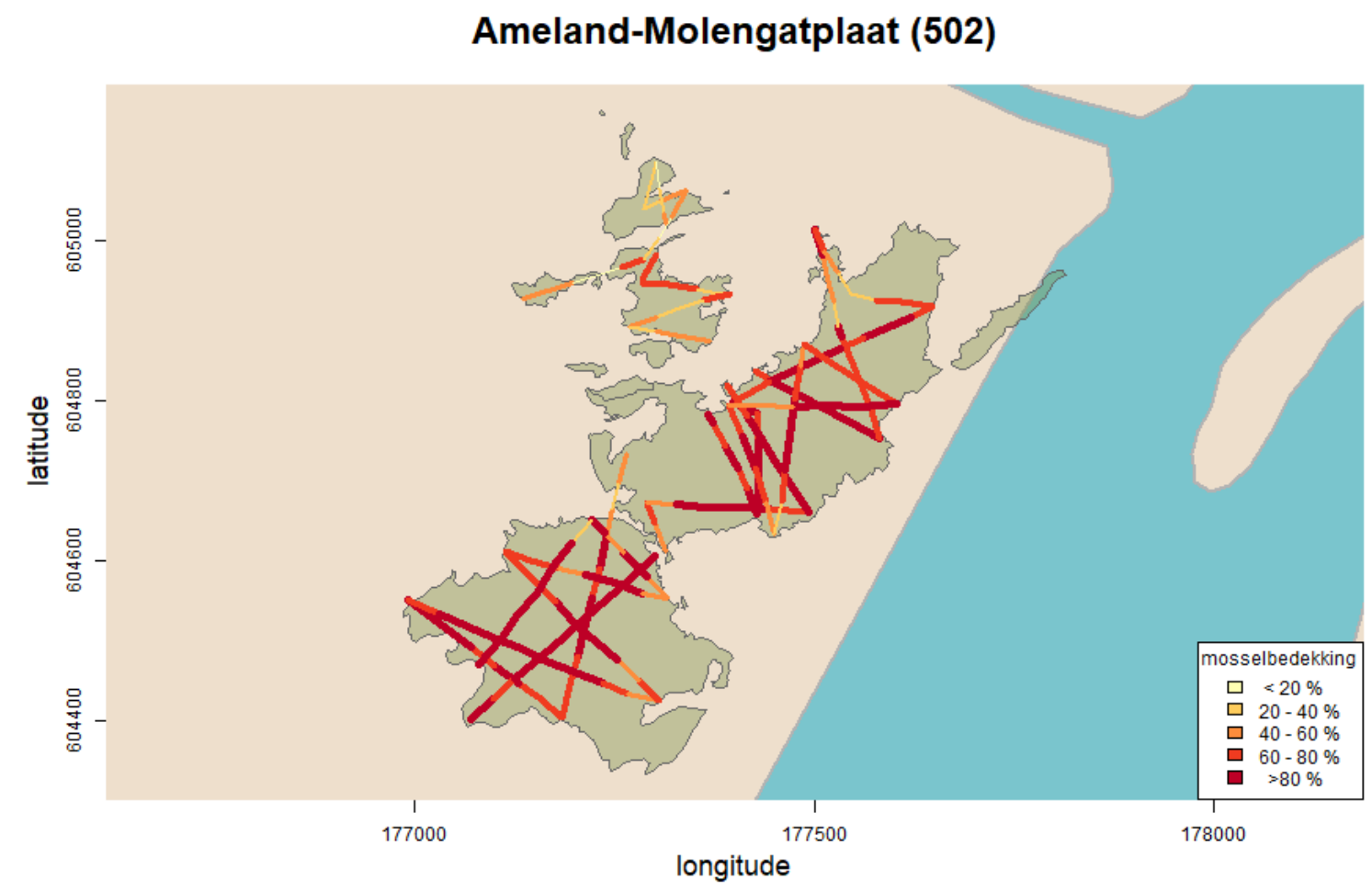

Figuur B2.1 Mosselbedekking op de subraaien op mosselbank 502 in 2019.

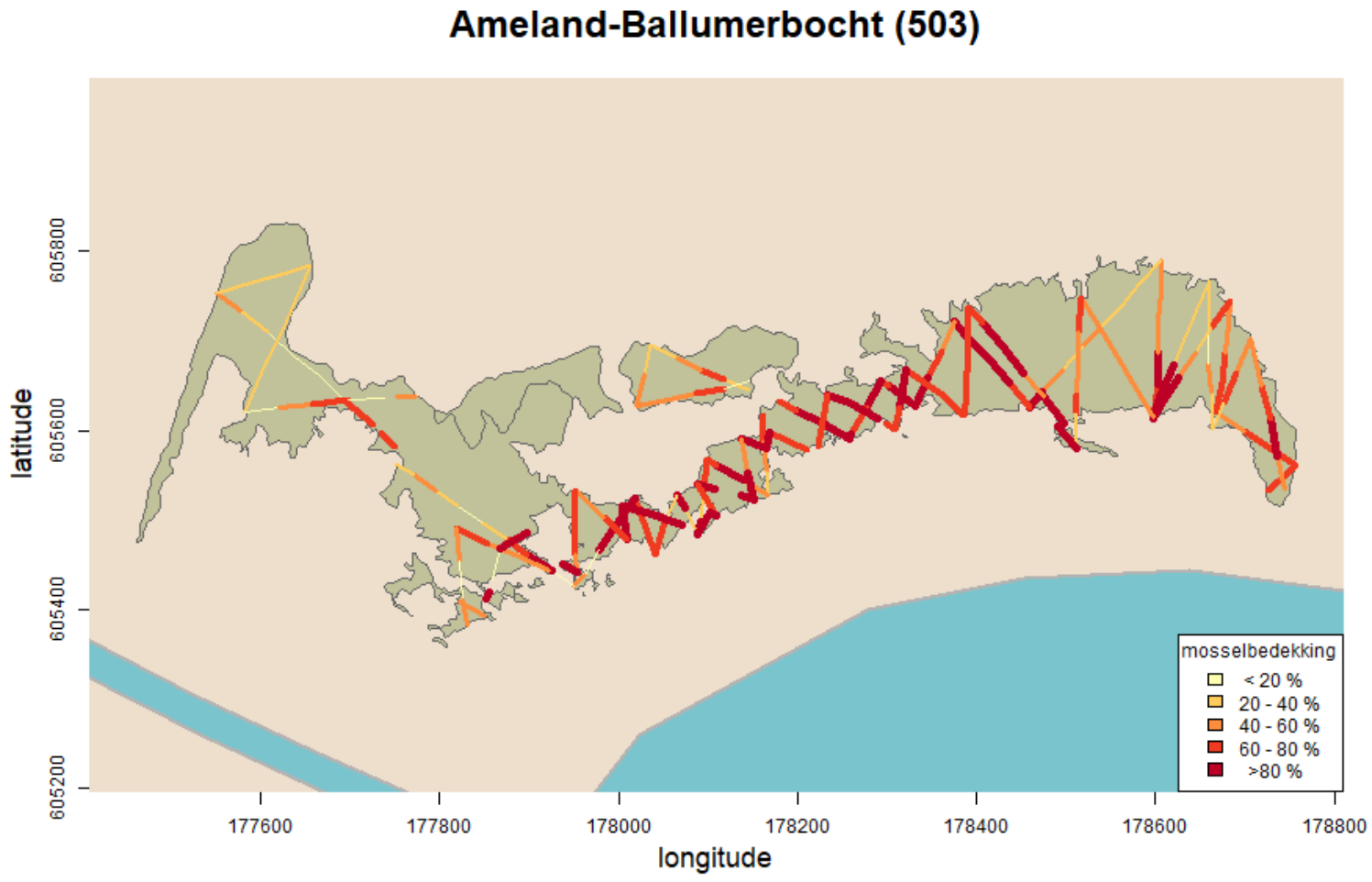

Figuur B2.2 Mosselbedekking op de subraaien op mosselbank 503 in 2019. 
(603)

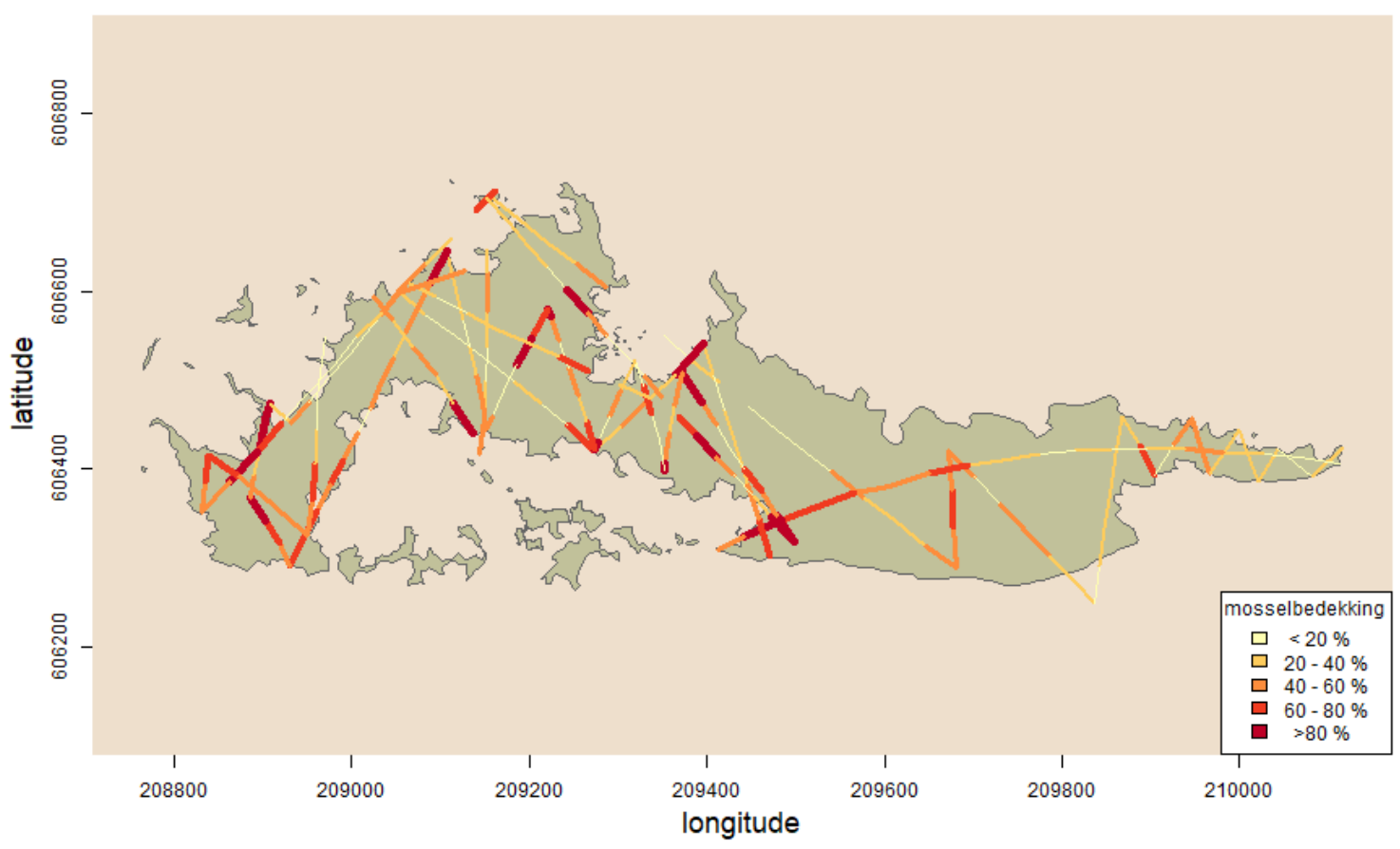

Figuur B2.3 Mosselbedekking op de subraaien op mosselbank 603 in 2019.

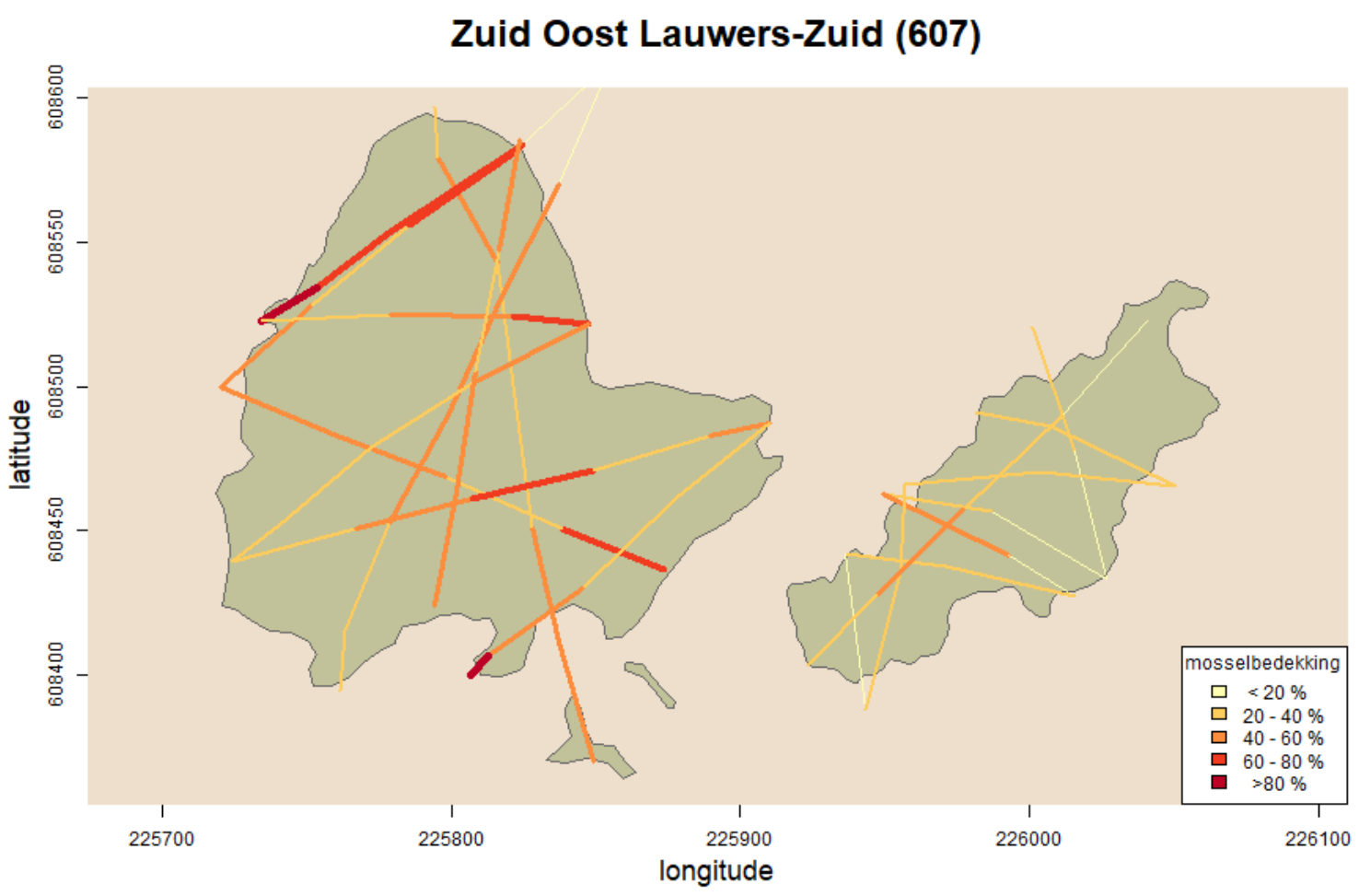

Figuur B2.4 Mosselbedekking op de subraaien op mosselbank 607 in 2019. 


\section{Schiermonnikoog - ZOL (640)}

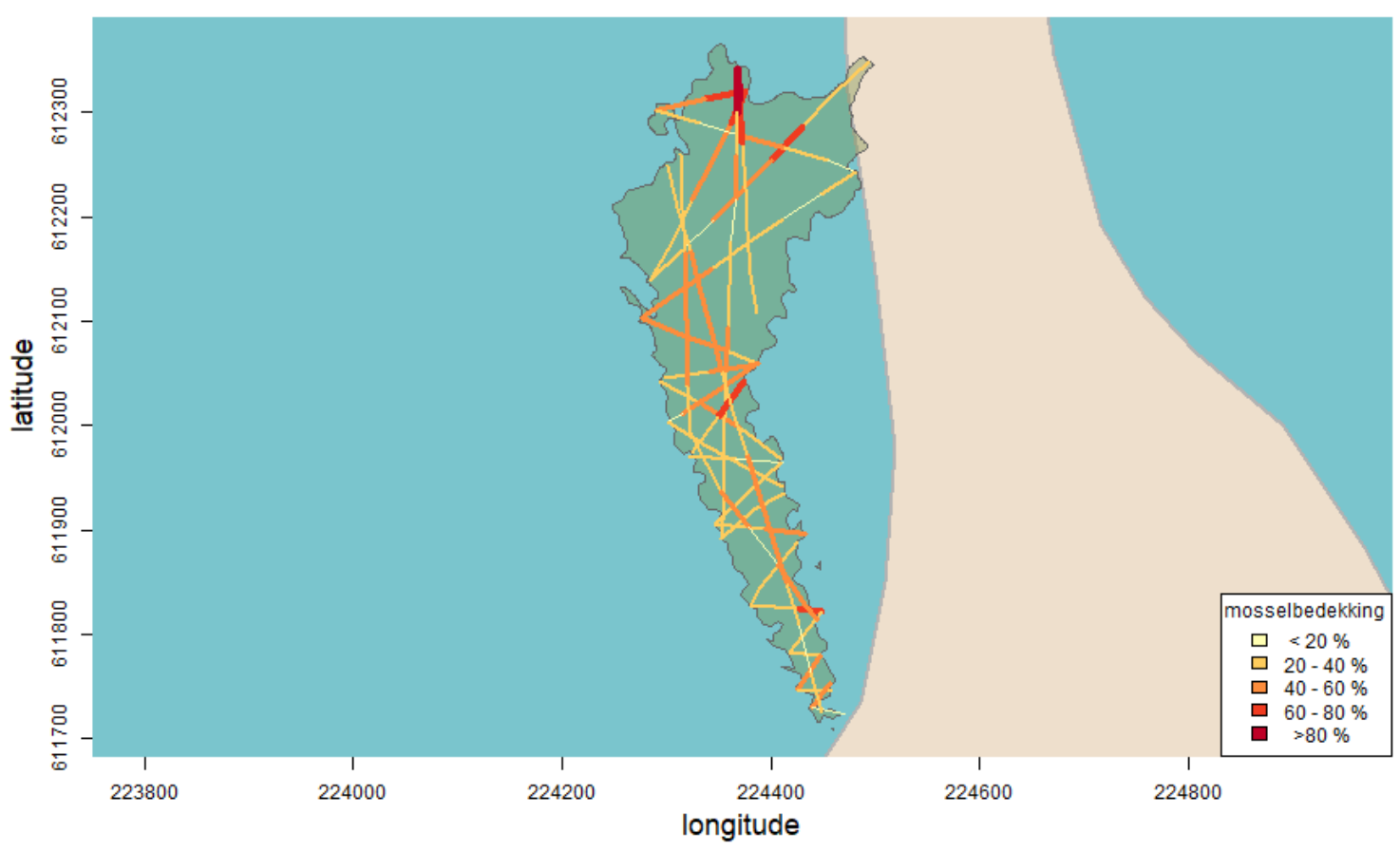

Figuur B2.5 Mosselbedekking op de subraaien op mosselbank 640 in 2019.

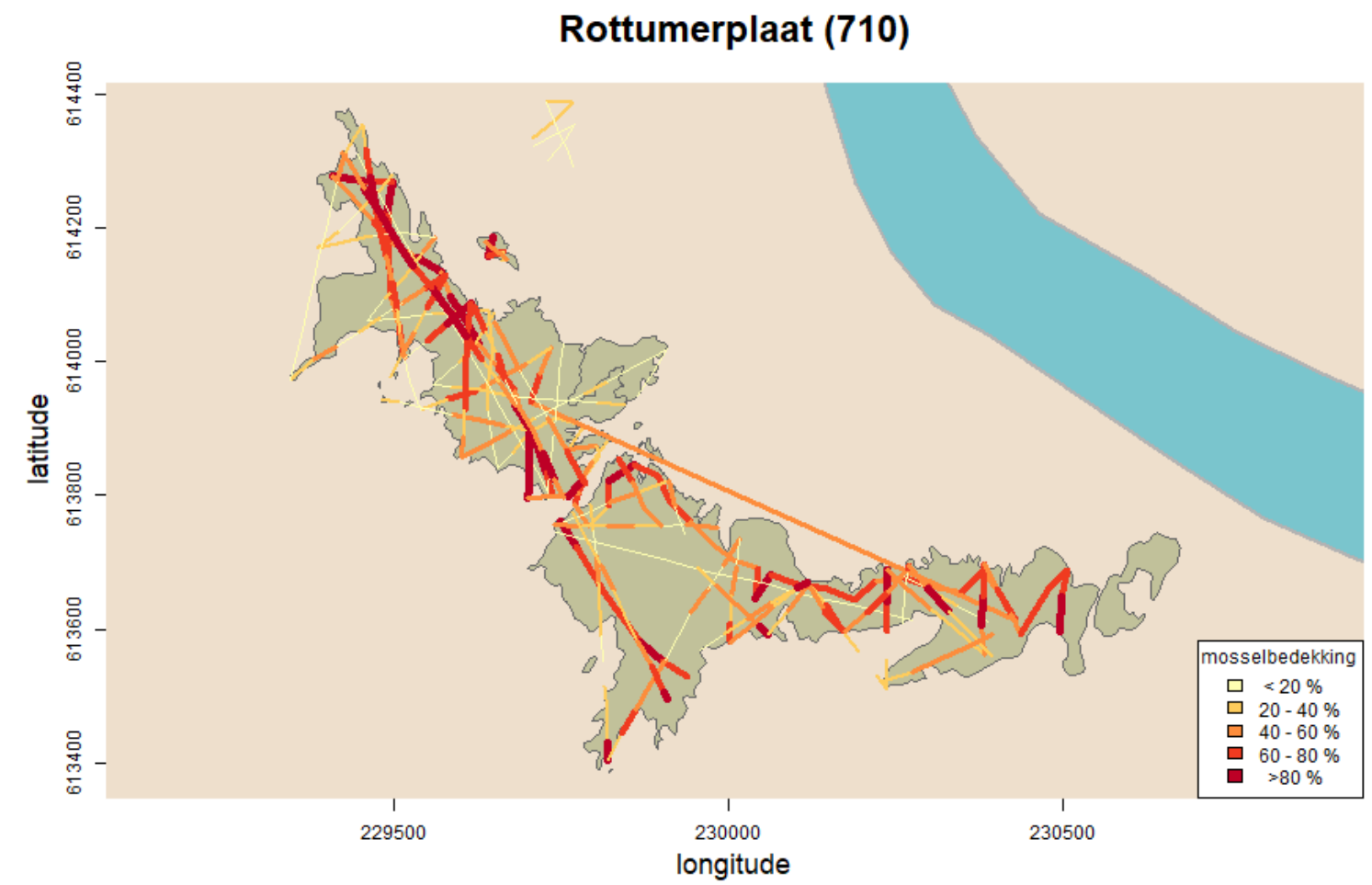

Figur B2.6 Mosselbedekking op de subraaien op mosselbank 710 in 2019. 


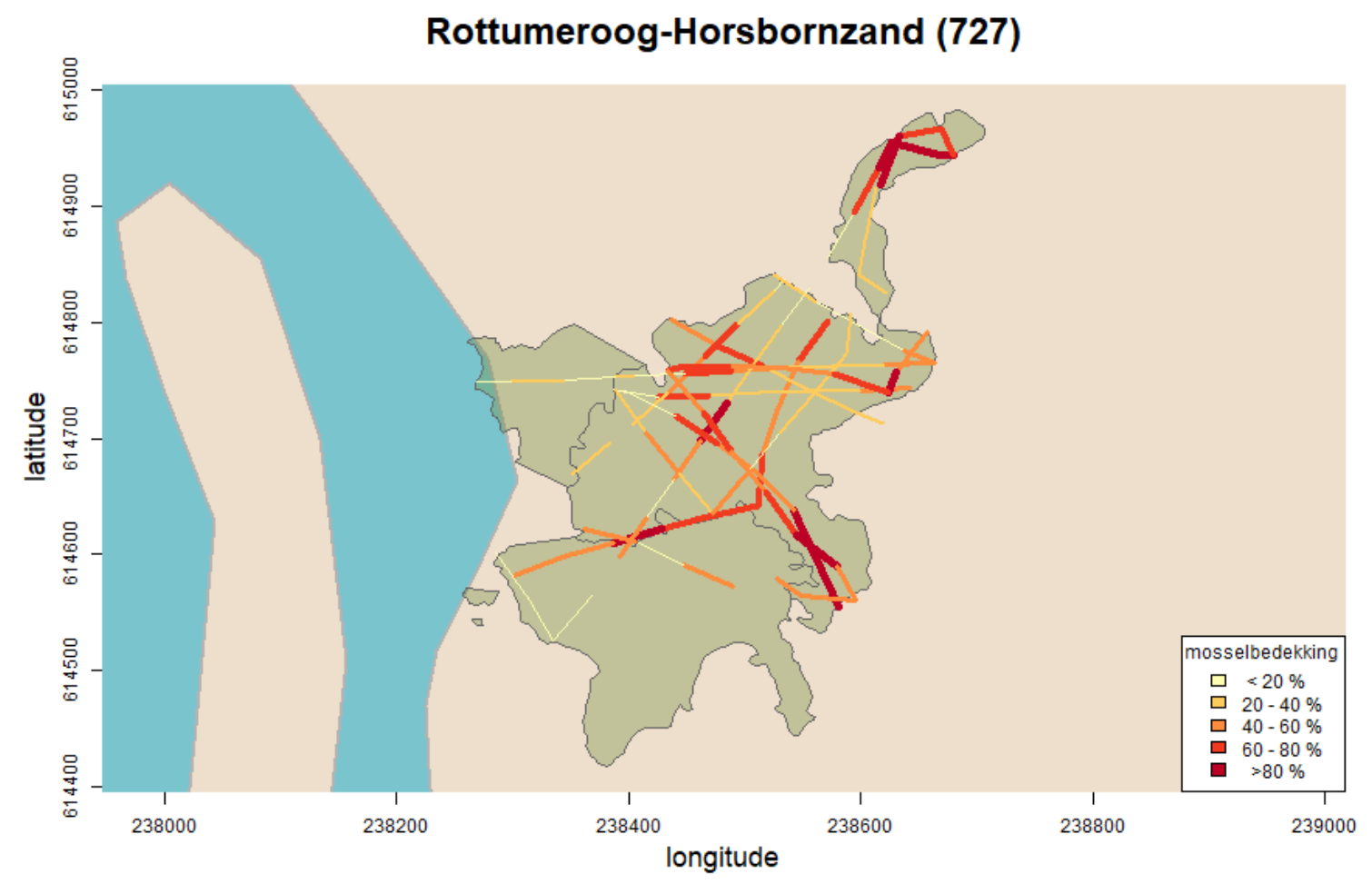

Figuur B2.7 Mosselbedekking op de subraaien op mosselbank 727 in 2019. 


\section{Bijlage 3 Kaart-Oesterbedekking}

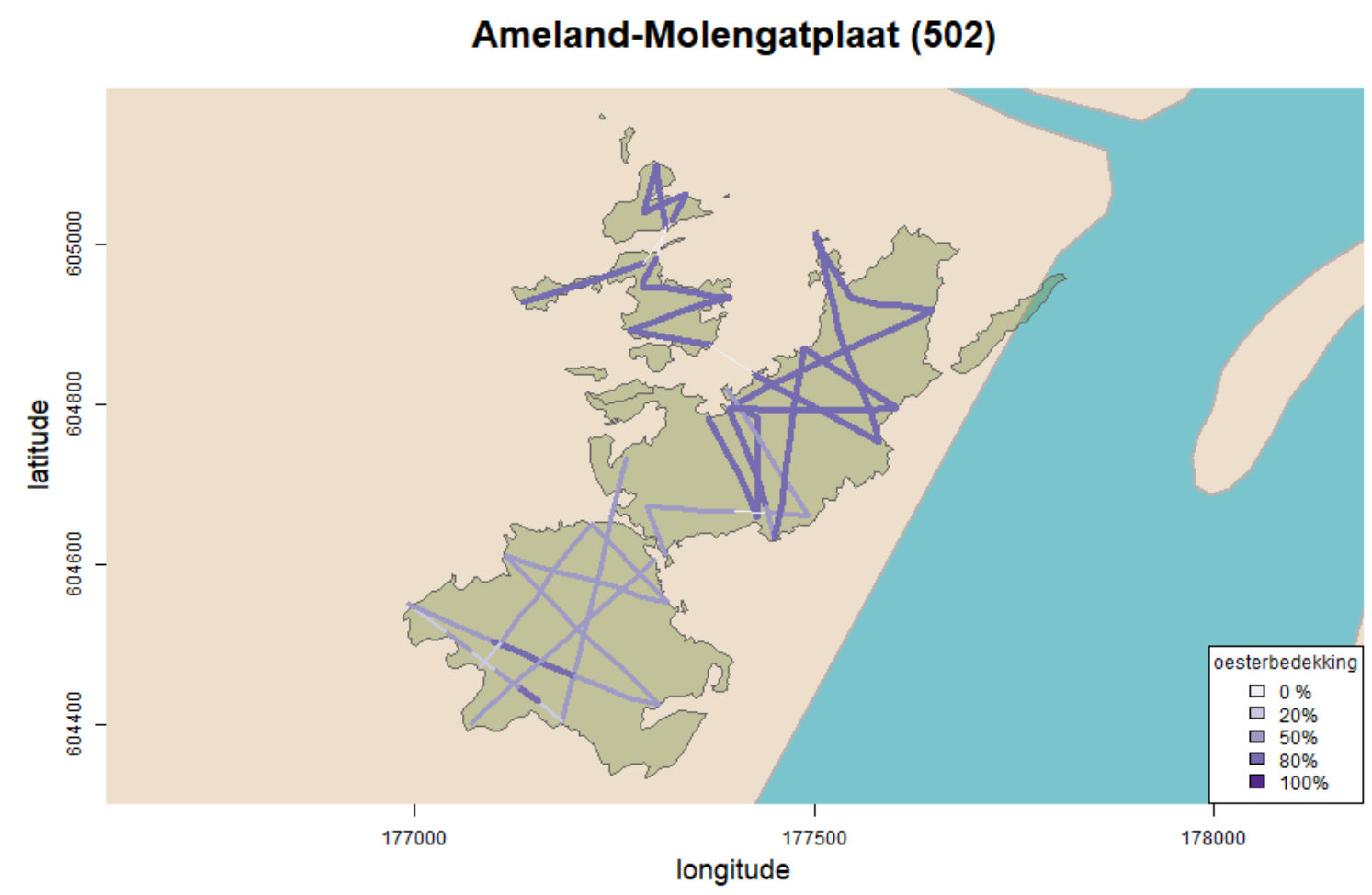

Figur B3.1 Oesterbedekking op de subraaien op mosselbank 502 in 2019.

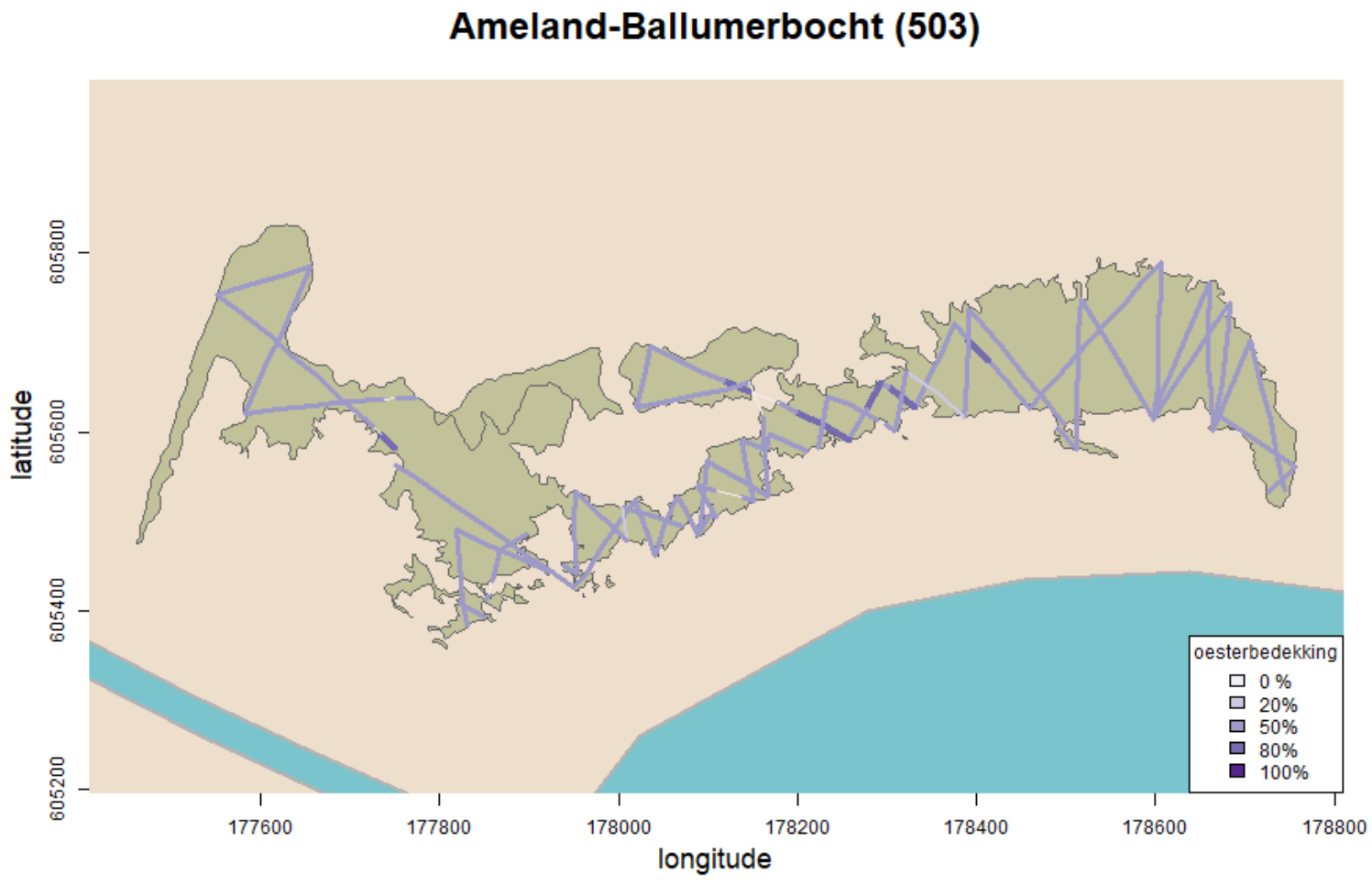

Figuur B3.2 Oesterbedekking op de subraaien op mosselbank 503 in 2019. 
(603)

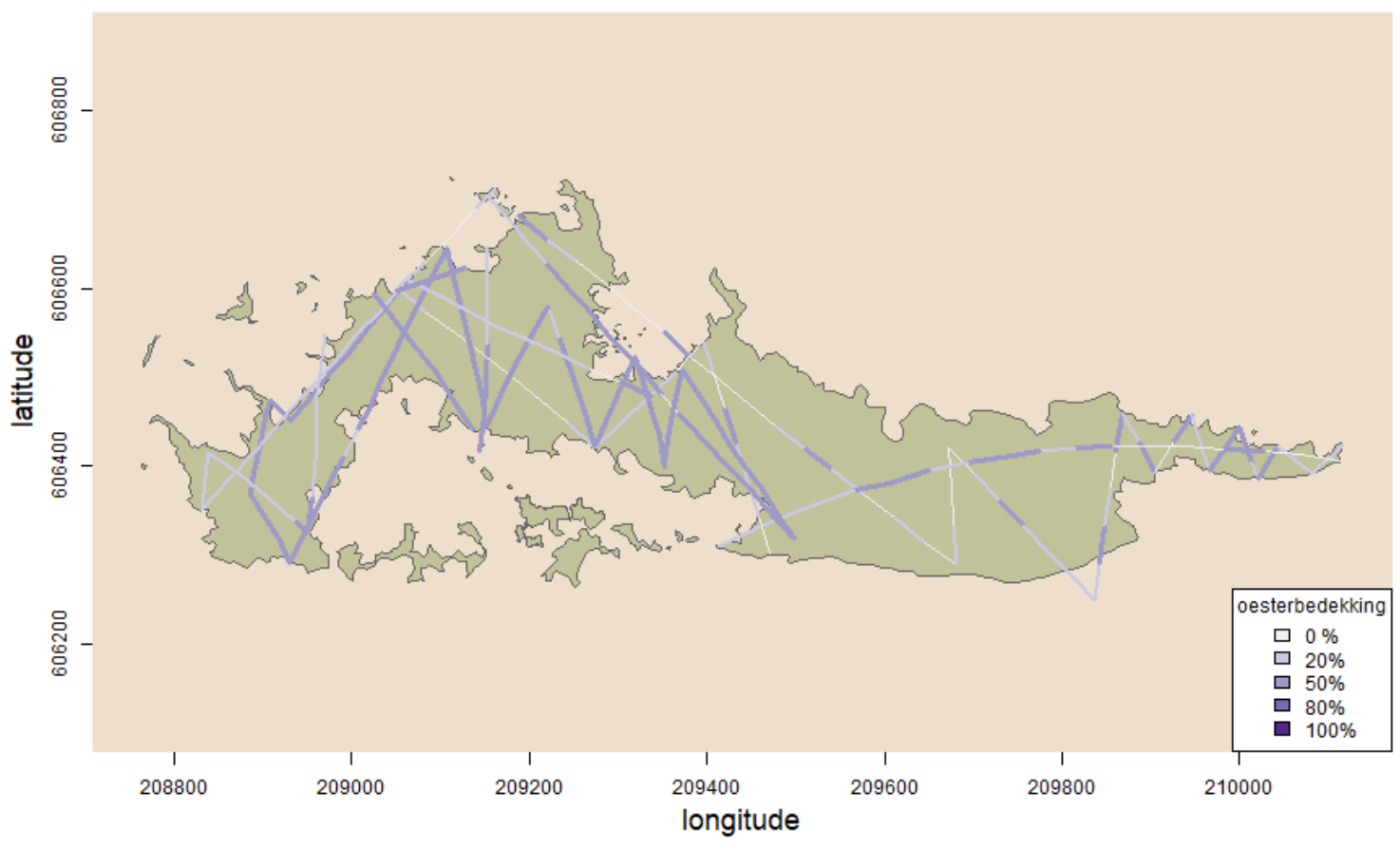

Figuur B3.3 Oesterbedekking op de subraaien op mosselbank 603 in 2019.

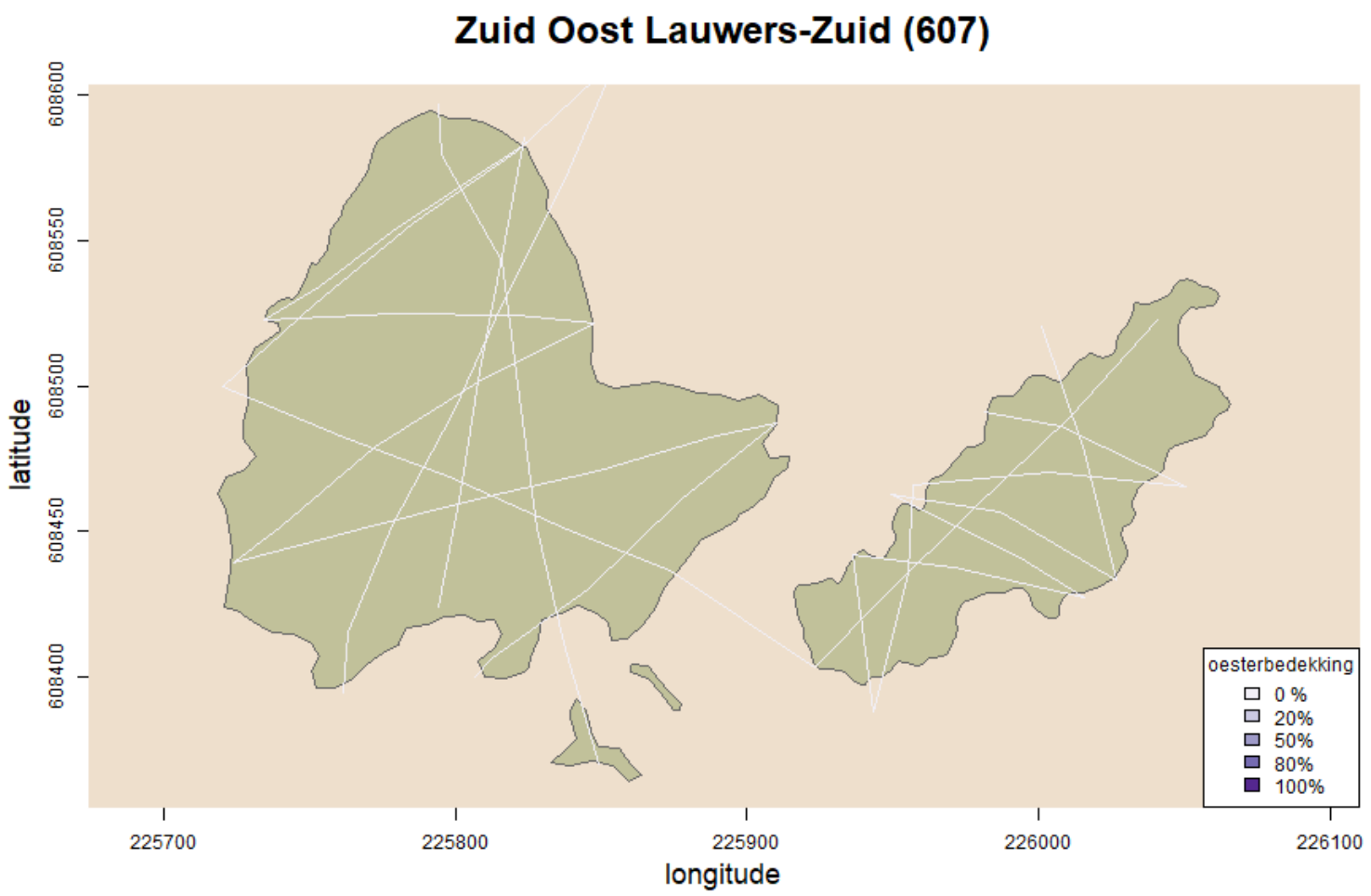

Figuur B3.4 Oesterbedekking op de subraaien op mosselbank 607 in 2019. 
Schiermonnikoog - ZOL (640)

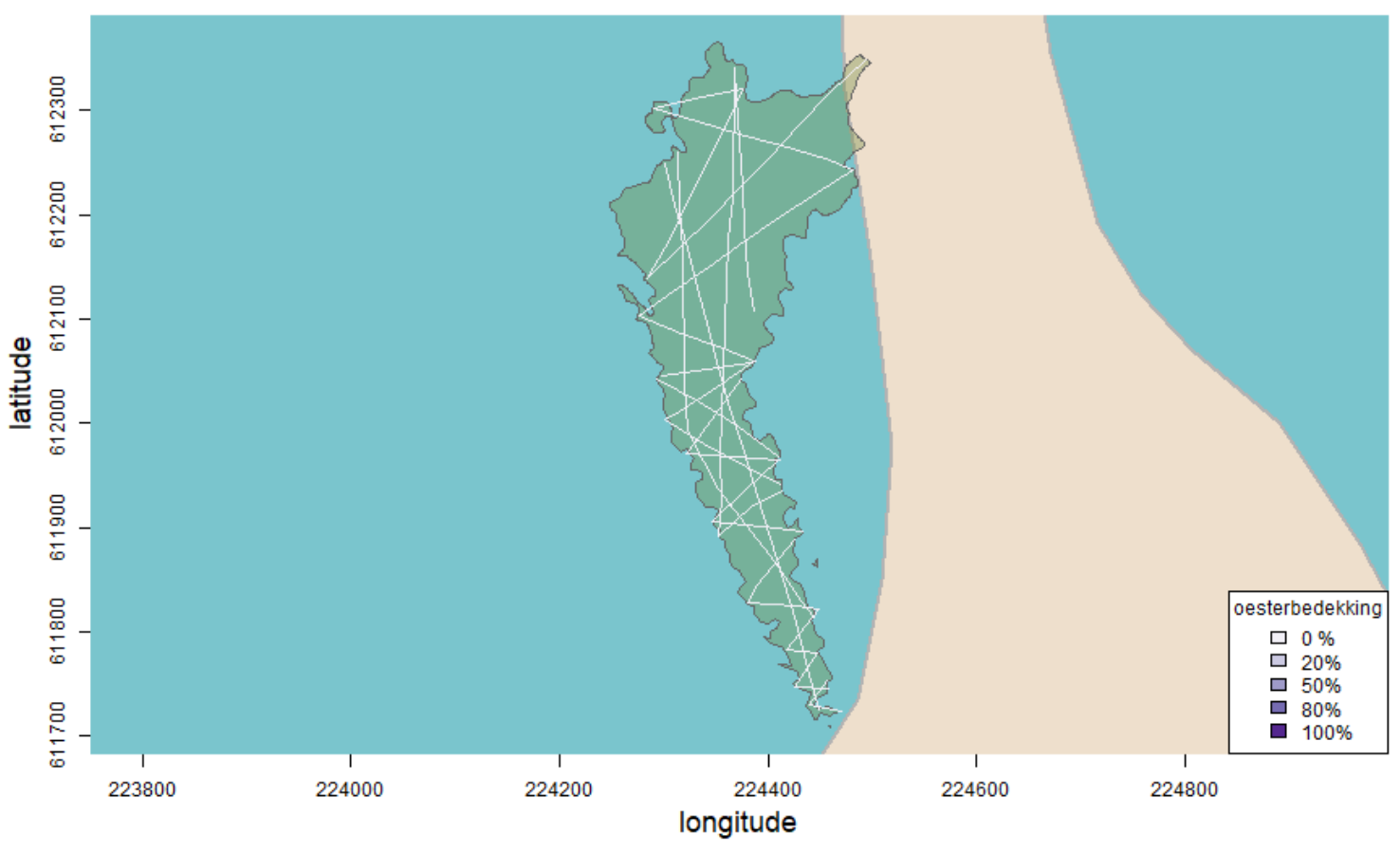

Figuur B3.5 Oesterbedekking op de subraaien op mosselbank 640 in 2019.

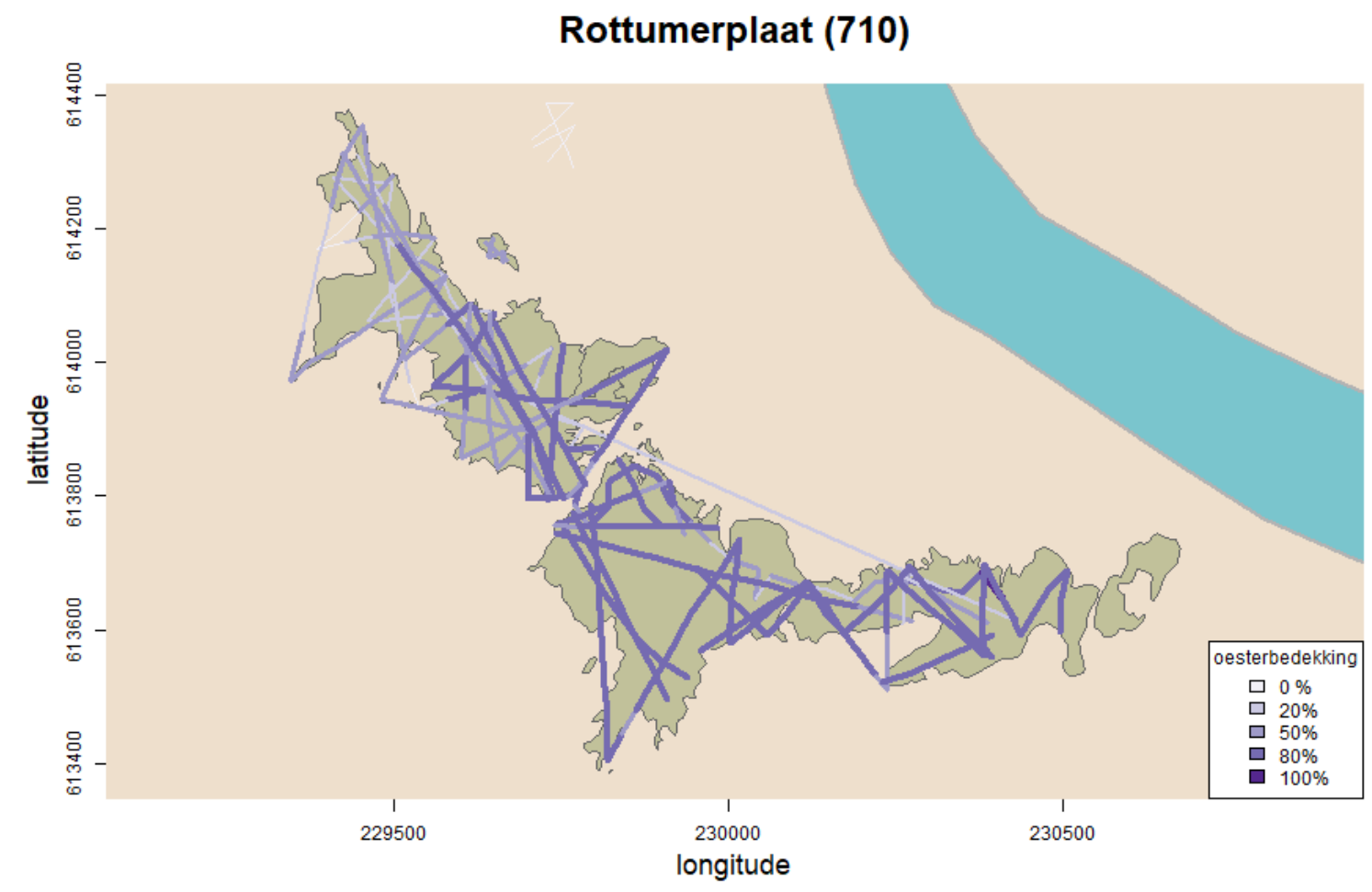

Figuur B3.6 Oesterbedekking op de subraaien op mosselbank 710 in 2019. 


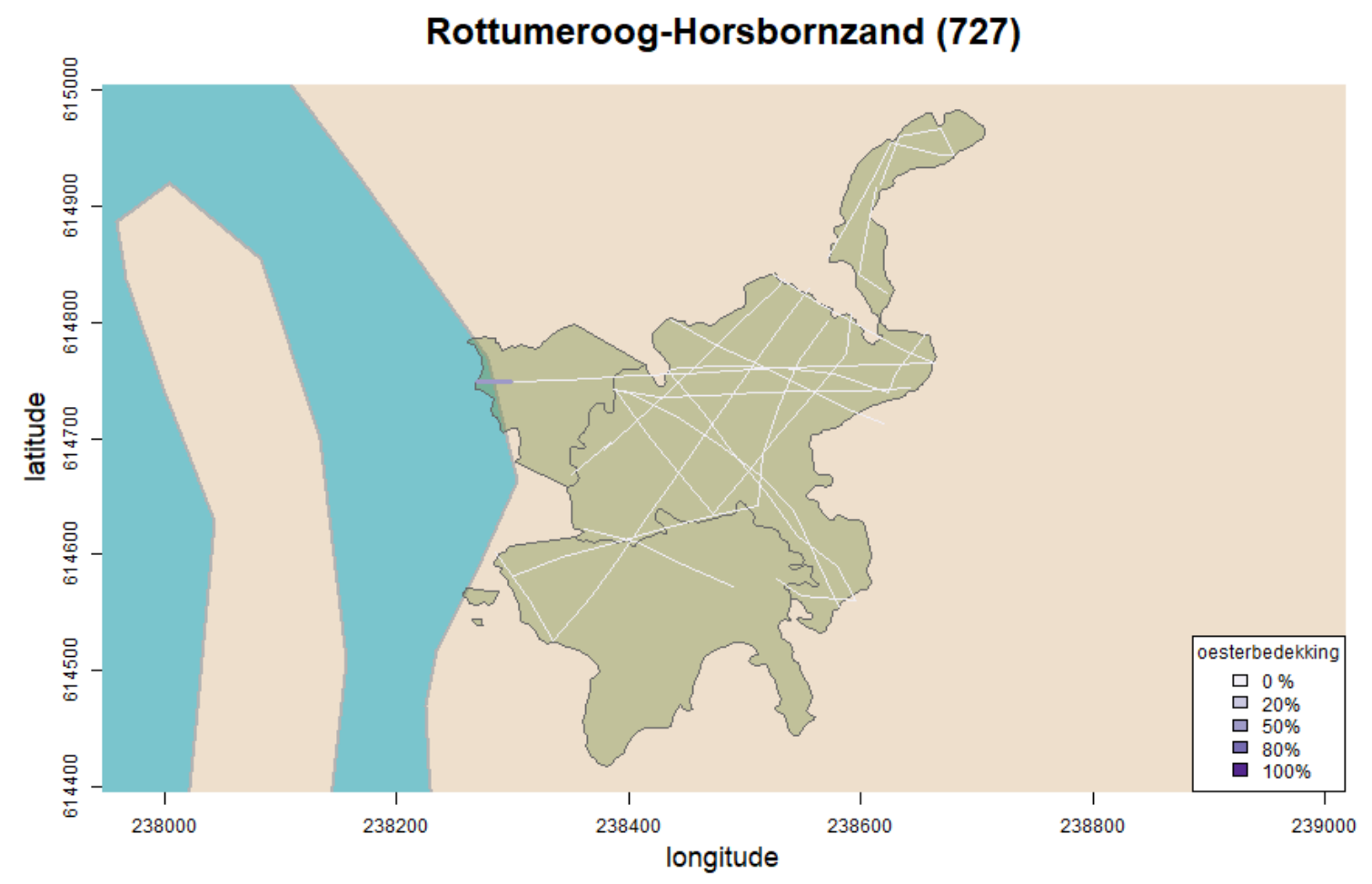

Figuur B3.7 Oesterbedekking op de subraaien op mosselbank 727 in 2019. 


\section{Bijlage 4 Ontwikkeling mosselpopulatie}

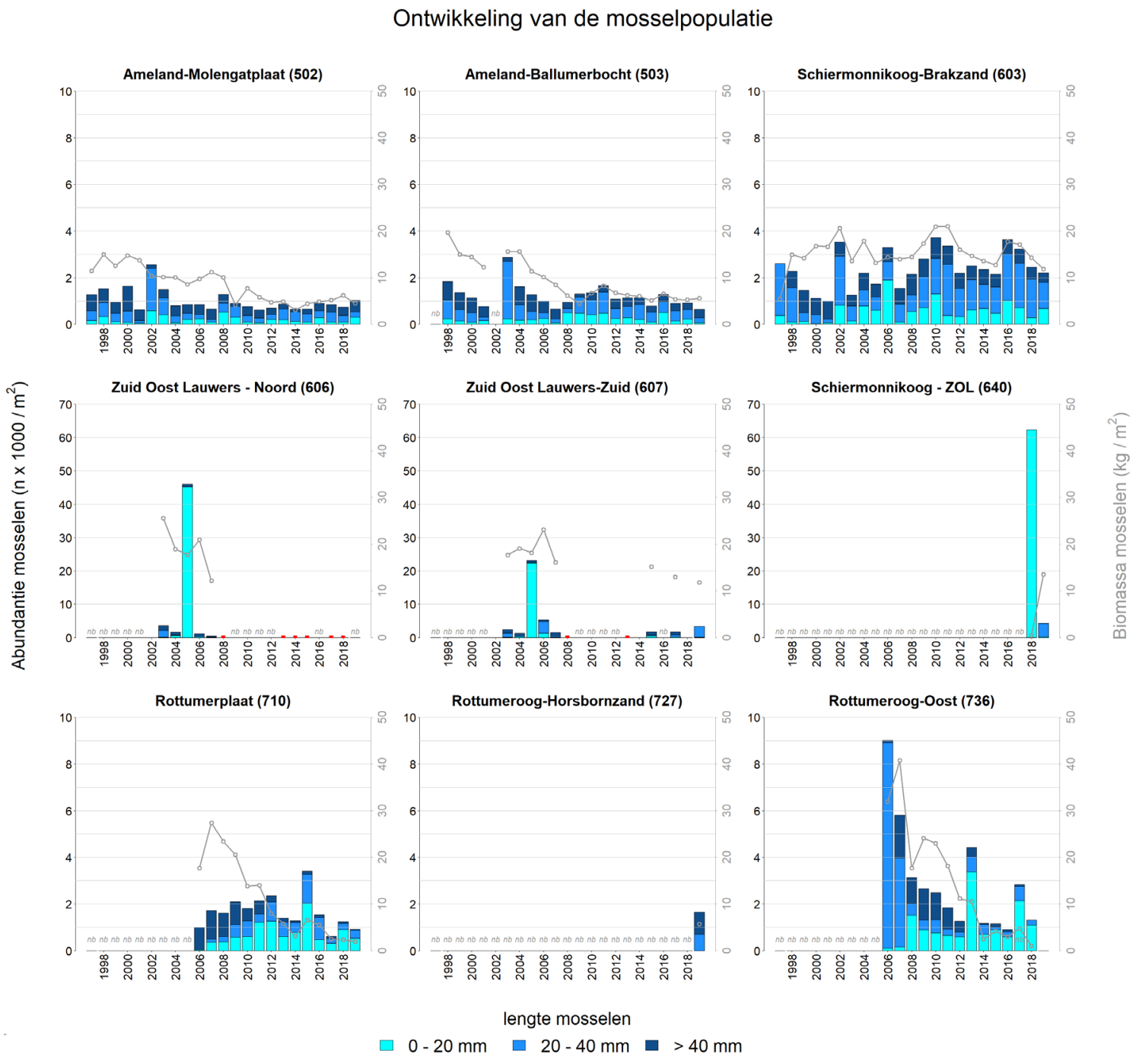

Figuur B4.1 Ontwikkeling van jaargemiddelde dichtheid ( $\left.\mathrm{n} \times 1000 / \mathrm{m}^{2}\right)$ en biomassa ( $\mathrm{kg}$ natgewicht $\left./ \mathrm{m}^{2}\right)$ mosselen zoals aangetroffen in de vierkantmonsters $\left(0,05 \mathrm{~m}^{2}\right)$ voor de banken 502, 503, 603, 606, 607, 640, 710, 727 en 736 in de periode 1997 t/m 2019 (of tot wanneer ze bezocht zijn/aanwezig waren). De dichtheden (onderverdeeld in drie lengteklassen) zijn weergegeven met balken en uitgezet op de linker $y$-as. De mosselbiomassa's zijn met grijze lijnen weergegeven en uitgezet op de rechter $y$-as. Wanneer een bank wel bezocht werd maar niet aanwezig was, is dit met een rode stip aangegeven. 

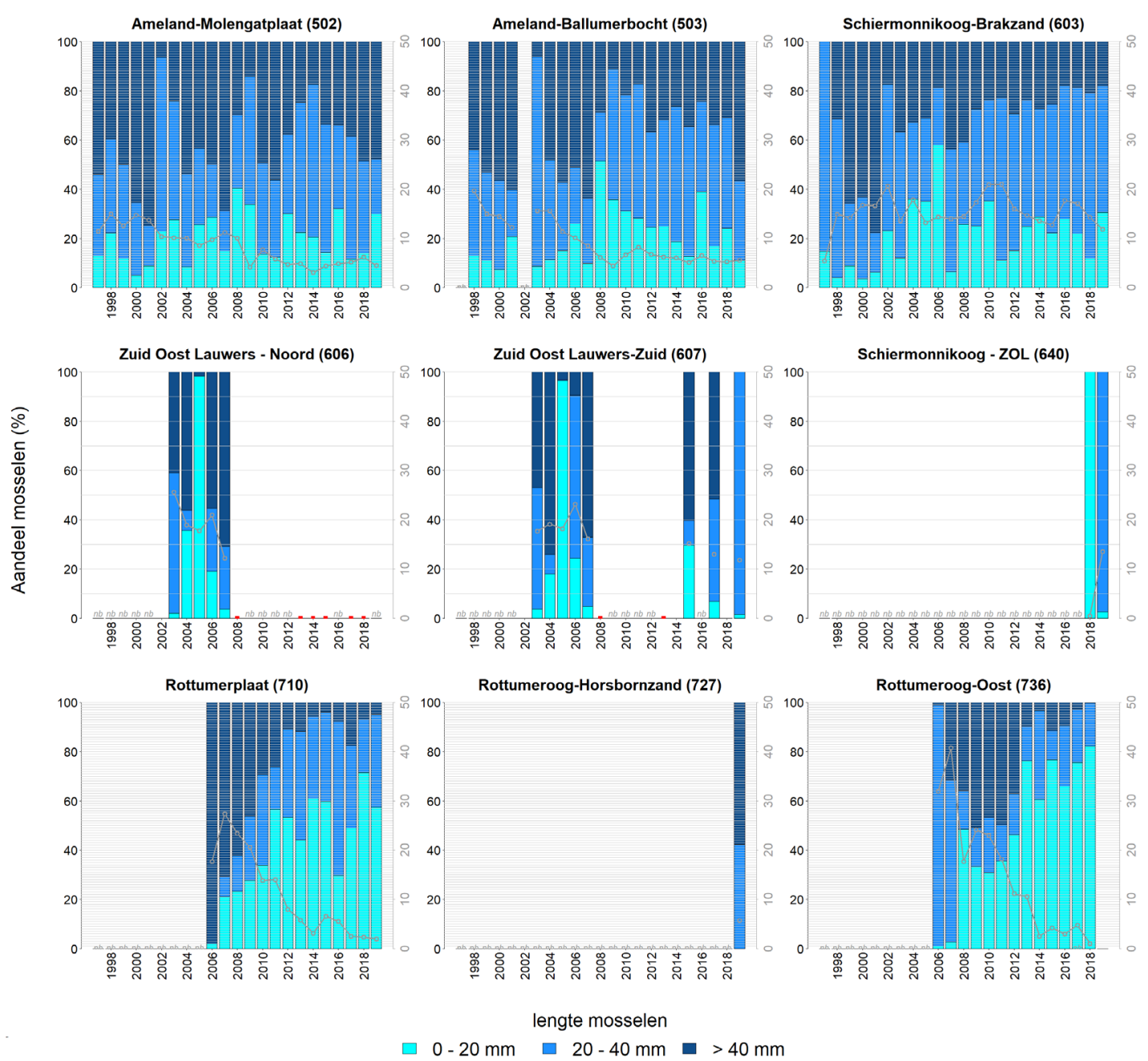

Figuur B4.2 Ontwikkeling van de jaargemiddelde mosselsamenstelling (procentueel aandeel van het aantal individuen per lengteklassen) en biomassa ( $\mathrm{kg}$ natgewicht $/ \mathrm{m}^{2}$ ) mosselen zoals aangetroffen in de vierkantmonsters (1/20 m²) voor de banken 502, 503, 603, 606, 607, 640, 710, 727 en 736 in de periode $1997 \mathrm{t} / \mathrm{m} 2019$ (of tot wanneer ze bezocht zijn/aanwezig waren). De dichtheden (onderverdeeld in drie lengteklassen) zijn weergegeven met balken en uitgezet op de linker $y$-as. De mosselbiomassa's zijn met grijze lijnen weergegeven en uitgezet op de rechter $y$-as. Wanneer een bank wel bezocht werd maar niet aanwezig was, is dit met een rode stip aangegeven. 


\section{Bijlage 5 Ontwikkeling oesterpopulatie}

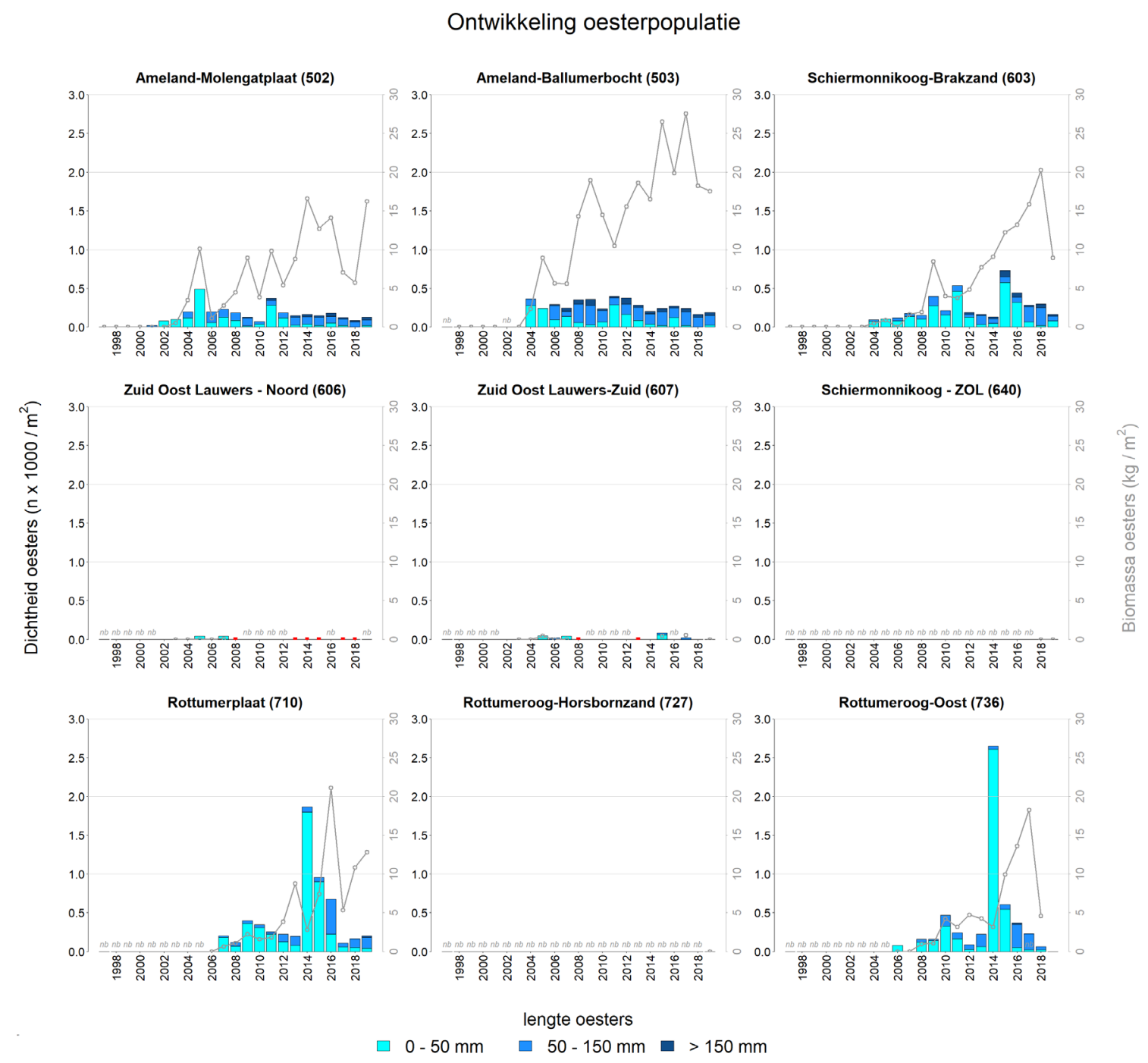

Figuur B5.1 Ontwikkeling van jaargemiddelde dichtheid ( $\left.\mathrm{n} \times 1000 / \mathrm{m}^{2}\right)$ en biomassa ( $\mathrm{kg}$ natgewicht $\left./ \mathrm{m}^{2}\right)$ Japanse oesters zoals aangetroffen in de vierkantmonsters $\left(1 / 20 \mathrm{~m}^{2}\right)$ voor de banken 502, 503, 603, 606, 607, 640, 710, 727 en 736 in de periode 1997 t/m 2019 (of tot wanneer ze bezocht zijn/aanwezig waren). De dichtheden (onderverdeeld in drie lengteklassen) zijn weergegeven met balken en uitgezet op de linker $y$-as. De oesterbiomassa's zijn met grijze lijnen weergegeven en uitgezet op de rechter $y$-as. Wanneer een bank wel bezocht werd maar niet aanwezig was, is dit met een rode stip aangegeven. 



\section{Verschenen documenten in de reeks Technical reports van de Wettelijke Onderzoekstaken Natuur}

\& Milieu

168 Arets, E.J.M.M., J.W.H van der Kolk, G.M. Hengeveld, J.P. Lesschen, H. Kramer, P.J. Kuikman \& M.J. Schelhaas (2020). Greenhouse gas reporting of the LULUCF sector in the Netherlands. Methodological background, update 2020.

169 Van Kraalingen, D., E.L. Wipfler, F. van den Berg, W.H.J. Beltman, M.M.S. ter Horst \& J.A. te Roller (2020). User manual for FOCUSSPIN version 3.3.

170 Bos-Groenendijk, G.I., C.A.M van Swaay (2020). Habitatrichtlijnrapportage 2019: Annex B Habitatrichtlijnsoorten; Achtergronddocument.

171 Janssen, J.A.M. (red.), R.J. Bijlsma (red.), G.H.P. Arts, M.J. Baptist, S.M. Hennekens, B. de Knegt, T. van der Meij, J.H.J. Schaminée, A.J. van Strien, S. Wijnhoven, T.J.W. Ysebaert (2020). Habitatrichtlijnrapportage 2019: Annex D Habitattypen. Achtergronddocument.

172 Van Kleunen, A., M. van Roomen, E. van Winden, M. Hornman, A. Boele, C. Kampichler, D. Zoetebier, H. Sierdsema \& C. van Turnhout (2020). Vogelrichtlijnrapportage 2013-2018 van Nederland - status en trends van soorten.

173 Glorius, S.T., A. Meijboom (2020). Ontwikkeling van de bodemdiergemeenschap in de geulen van referentiegebied Rottum;

Tussenrapportage 13 jaar na sluiting (najaar 2018).

174 Kuindersma, W., D. van Doren, R. Arnouts, D.A. Kamphorst, J.G. Nuesink, E. de Wit-de Vries (2020). Realisatie Natuurnetwerk door provincies. Achtergrondstudie bij de Tweede Lerende Evaluatie Natuurpact.

175 Bouwma, I.M., D.A. Kamphorst, D. van Doren, T.A. de Boer, A.E. Buijs, C.M. Goossen, J.L.M. Donders, J.Y. Frissel, S. van Broekhoven (2020). Provinciaal beleid voor maatschappelijke betrokkenheid bij natuur het beleid nader bekeken in 8 casussen. Achtergrondstudie bij de Tweede Lerende Evaluatie Natuurpact.

176 Gerritsen, A.L., H. Agricola, C. Aalbers, J. van Os (2020). Natuur en landbouw verbinden. Achtergrondstudie bij de Tweede Lerende Evaluatie Natuurpact.

177 Brouwer, F., D.J.J. Walvoort (2020). Basisregistratie Ondergrond (BRO) Actualisatie bodemkaart. Herkartering van de veengebieden aan de flanken van de Utrechtse Heuvelrug.

178 Bruggen, C. van, A. Bannink, C.M. Groenestein, J.F.M. Huijsmans, L.A. Lagerwerf, H.H. Luesink, G.L. Velthof \& J. Vonk (2020). Emissies naar lucht uit de landbouw, 19902018; Emissies van ammoniak, stikstofoxide, lachgas, methaan, niet-methaan vluchtige organische stoffen, fijnstof en koolstofdioxide uit kalkmeststoffen - Berekeningen met het model NEMA.

179 Knegt, de B., M. Pleijte, E. de Wit-de Vries, I. Bouwma, F. Kistenkas, W. Nieuwenhuizen (2020). Samenhang Klimaatakkoord en natuurbeleid. Proces en implementatie van het Klimaatakkoord door provincies en maatschappelijke partijen en de potentiële effecten op biodiversiteitsdoelen van de Vogelen Habitatrichtlijn.

180 Mattijssen T.J.M., M. Pleijte, J. Dengerink, T. Koster, M. Visscher (2020). Indicatoren voor burgerbetrokkenheid bij natuur: een zoektocht naar nieuwe aanknopingspunten voor monitoring.

181 Kamphorst, D.A., M. Pleijte, F. Kistenkas (2020). Uitvoering van de Vogel- en Habitatrichtlijn in de praktijk: spanningen en mogelijke oplossingsrichtingen.

182 Elschot K., M.E.B. Van Puijenbroek, D.D.G. Lagendijk, J-T. Van der Wal, C. Sonneveld (2020). Lange-termijnontwikkeling van kwelders in de Waddenzee (1960-2018).

183 Koffijberg K., P. de Boer, S.C.V. Geelhoed, J. Nienhuis, K. Oosterbeek, J. Postma (2020). Broedsucces van kustbroedvogels in de Waddenzee in 2018.

184 IJsseldijk, L.L., M.J.L. Kik, L. van Schalkwijk \& A. Gröne (2020). Postmortaal onderzoek van bruinvissen (Phocoena phocoena) uit Nederlandse wateren, 2019. Biologische gegevens, gezondheidsstatus en doodsoorzaken.

185 Os, J. van, L.J.J. Jeurissen, J.C. Verkaik (2020) Rekenregels schapen en geiten voor de landbouwtelling; Verantwoording van het gebruik van het Identificatie \& Registratiesysteem

186 Bakker, G., M. Heinen, H.P.A. Gooren, W.J.M. de Groot, P.D. Peters (2020). Hydrofysische gegevens van de bodem in de Basisregistratie Ondergrond (BRO) en het Bodemkundig Informatie Systeem (BIS); Update 2019.

187 Kuindersma, W., E. de Wit - de Vries, F.G. Boonstra, M. Pleijte, D.A. Kamphorst (2020). Het Nederlandse natuurbeleid in zijn institutionele context. Beschrijving en analyse van de interne en externe congruentie van het Nederlandse natuurbeleidsarrangement in relatie tot landbouwbeleid, waterbeleid (voor de grote rivieren) en recreatiebeleid (19752018).

188 Kuiters, A.T., G.A. de Groot, D.R. Lammertsma, H.A.H. Jansman, J. Bovenschen (2020). Genetische monitoring van de Nederlandse otterpopulatie; Ontwikkeling van populatieomvang en genetische status 2019/2020. 
192 Glorius, S.T. \& A. Meijboom (2020). Ontwikkeling van enkele droogvallende mosselbanken in de Nederlandse Waddenzee; situatie 2019 



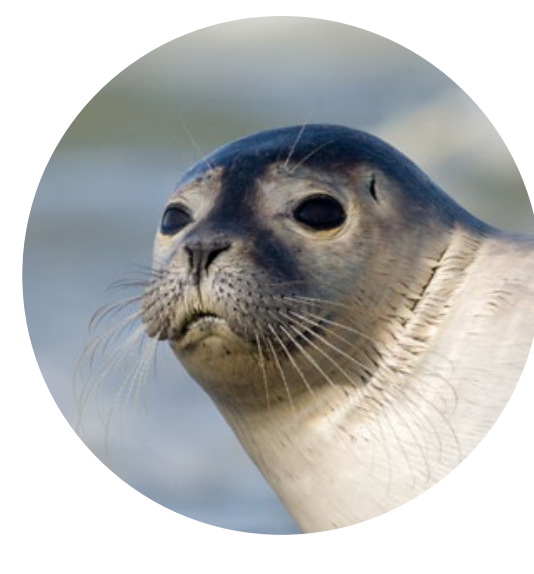

Thema Informatievoorziening Natuur Wettelijke Onderzoekstaken Natuur \& Milieu

Postbus 47

6700 AA Wageningen

T (0317) 485471

E info.wnm@wur.nl

ISSN 2352-2739

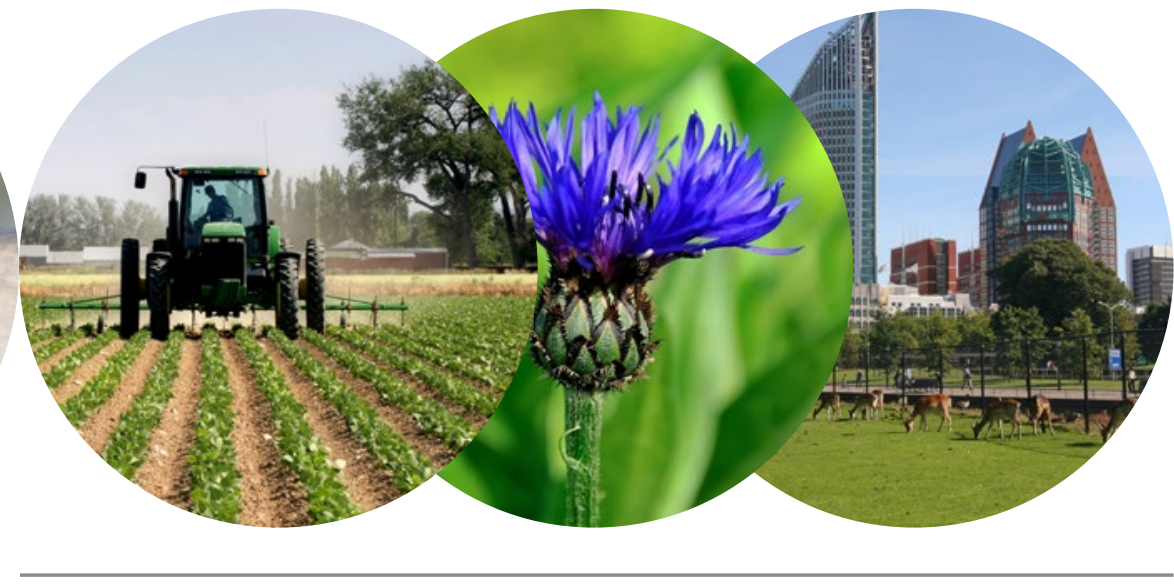

De missie van Wageningen University \& Research is 'To explore the potential of nature to improve the quality of life'. Binnen Wageningen University \& Research bundelen Wageningen University en gespecialiseerde onderzoeksinstituten van Stichting Wageningen Research hun krachten om bij te dragen aan de oplossing van belangrijke vragen in het domein van gezonde voeding en leefomgeving. Met ongeveer 30 vestigingen, 6.500 medewerkers ( $5.500 \mathrm{fte}$ ) en 12.500 studenten behoort Wageningen University \& Research wereldwijd tot de aansprekende kennisinstellingen binnen haar domein. De integrale benadering van de vraagstukken en de samenwerking tussen verschillende disciplines vormen het hart van de unieke Wageningen aanpak. 